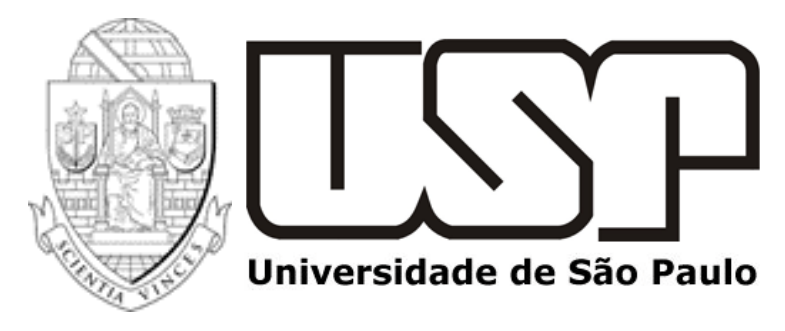

MARIANA DE PAIVA BATISTA

Perfil molecular do carcinoma de células claras de ovário e sua correlação clínica na experiência de quatro instituições.

Ribeirão Preto 


\title{
Perfil molecular do carcinoma de células claras de ovário e sua correlação clínica na experiência de quatro instituições.
}

\author{
Tese apresentada ao Programa de Pós- \\ Graduação em Oncologia Clínica, Células \\ Tronco e Terapia Celular da Faculdade de \\ Medicina de Ribeirão Preto - Universidade de \\ São Paulo (FMRP-USP) para obtenção do \\ Título de Doutor.
}

Área de concentração: Diferenciação Celular Normal e Neoplásica

Orientador: Prof. Dr. Eduardo Magalhães Rego 
FICHA CATALOGRÁFI CA

Batista, Mariana de Paiva Batista.

Perfil molecular do carcinoma de células claras de ovário e sua correlação clínica na experiência de quatro instituições. Ribeirão Preto, 2021.

96 p. : il.

Tese de Doutorado, apresentada à Faculdade de Medicina de Ribeirão Preto-USP. Área de concentração: Diferenciação celular normal e neoplásica.

Orientador: Prof. Dr. Eduardo Magalhães Rego

1.Carcinoma de células claras de ovário. 2. Variação do número de cópias. 
Nome: BATISTA, Mariana de Paiva

Título: Perfil molecular do carcinoma de células claras de ovário e sua correlação clínica na experiência de quatro instituições.

Tese apresentada ao Programa de Pós-Graduação em Oncologia Clínica, Células-Tronco e Terapia Celular da Faculdade de Medicina de Ribeirão Preto da Universidade de São Paulo, como requisito para obtenção do Título de Doutor.

Área de concentração: Diferenciação celular normal e neoplásica.

Aprovado em:

\section{Banca Examinadora}

Prof. Dr. Instituição:

Julgamento: Assinatura:

Prof. Dr. Instituição:

Julgamento: Assinatura:

Prof. Dr. Instituição:

Julgamento: Assinatura:

Prof. Dr. Instituição:

Julgamento: Assinatura:

Prof. Dr. Instituição: Assinatura: 


\section{APOIO E SUPORTE FINANCEIRO}

Este trabalho foi realizado com apoio das seguintes instituições:

1. Centro de Terapia Celular - CTC-CEPID-FAPESP (2013/08135-2)

2. Coordenação de Aperfeiçoamento de Pessoal de Nível Superior Brasil (CAPES)

3. Fundação Hemocentro de Ribeirão Preto (FUNDHERP)

4. Faculdade de Medicina de Ribeirão Preto da Universidade de São Paulo (FMRP-USP)

5. GEICO (Grupo Español de Investigación en Cáncer de Ovario) 


\section{AGRADECIMENTOS}

Agradeço imensamente aos meus pais por não medirem esforços para viabilizar todas as oportunidades possíveis para meu crescimento profissional e pessoal. Agradeço também a eles e à minha irmã o empenho em compreender e apoiar minhas escolhas e inseguranças em um mundo profissional tão distinto da engenharia que lhes é habitual. Vocês me inspiram e impulsionam, obrigada.

Agradeço ao Prof Eduardo Rego pelo apoio e orientação acadêmica e profissional durante anos. Sou muito grata pela confiança depositada em mim para o desenvolvimento deste projeto e pelas oportunidades oferecidas neste caminho.

Agradeço à equipe da oncologia clínica e do laboratório de hematologia do HCFMRP por terem me ensinado o que está e o que não está contido nos livros, e assim terem se tornado minha segunda casa por anos.

Ao Professor Poveda, agradeço e admiro todo seu empenho e preocupação em transpor fronteiras geográficas para apoiar e incentivar o desenvolvimento do conhecimento e da pesquisa em oncologia ginecológica. Saiba que aqui terá uma semente de seu esforço.

Estendo em seu nome o agradecimento a todos do Instituto Valenciano de Oncologia. $\mathrm{O}$ carinho, paciência e amizade que tiveram com uma estrangeira pouco fluente em espanhol e pouco conhecedora de biologia molecular, fez dali um refúgio de boas lembranças e inspiração que sempre levo comigo.

Agradeço muito ao Dr Martín Roffé pela paciência e disponibilidade em acompanhar e ensinar todo o desenvolvimento da análise de dados genômicos. Este projeto não teria sido o mesmo sem a sua participação.

A todos agradeço por tornarem todos estes caminhos trilhados tão engrandecedores, valorosos e inspiradores. 
"Caminante, son tus huellas el camino y nada más;

Caminante, no hay camino, se hace camino al andar. $\mathrm{Al}$ andar se hace el camino, y al volver la vista atrás se ve la senda que nunca se ha de volver a pisar.

Caminante no hay caminho sino estelas en la mar." 


\section{RESUMO}

Batista, Mariana de Paiva. Perfil molecular do carcinoma de células claras de ovário e sua correlação clínica na experiência de quatro instituições. Tese de Doutorado - Programa de Pós-Graduação em Oncologia Clínica, Células Tronco e Terapia Celular da Faculdade de Medicina de Ribeirão Preto - Universidade de São Paulo (FMRP-USP). Departamento de Clínica Médica, Divisão de Oncologia Clínica. 2021.

O carcinoma de células claras de ovário (CCCO) representa uma neoplasia rara, agressiva e quimiorresistente. Diferentes incidências geográficas e étnicas do CCCO já foram descritas, com destaque para a alta incidência em países asiáticos. Devido a raridade, há uma escassez de informações sobre CCCO na América Latina (A.L.) e em outros países. Neste estudo descrevemos duas coortes de 33 pacientes diagnosticadas com CCCO na A.L. (24 do Brasil e 9 da Costa Rica) e uma coorte de 27 pacientes da Espanha. Uma maior frequência de expressão aberrante de TP53 foi observada na coorte brasileira e a mediana do tempo de Sobrevida Global (S.G.) não foi significativamente diferente entre as coortes. Em sequência, as pacientes foram classificadas em três subgrupos genômicos distintos conforme previamente descrito por Tan et al. (TAN et al., 2011): Simplex-like (Sxl)(n=12), Firestorm-like (FSl) $(n=2)$ e Sawtooth-like (STl)(n=12). Nenhum padrão genômico foi associado ao desfecho clínico. Por fim, a análise genômica foi expandida utilizando-se a Plataforma OncoScan. Pacientes apresentando $M Y C$-amplificado de forma concomitante a perda da região cromossômica de 13q12-q13, a qual inclui o gene BRCA2 (subgrupo MB), representaram as pacientes que sobreviveram a um período mais longo em comparação às pacientes que não possuíam tais alterações. Por outro lado, as pacientes não-MB e portadoras de um elevado número (>30) de alterações no número de cópias (ANC) apresentam a pior sobrevida (subgrupo PS). Além disso, a amplificação do gene ASHIL foi associado a uma SG mais curta. Não foram observadas diferenças significativas nas frequências dos perfis genômicos ou dos subgrupos MB e PS entre as coortes da América Latina e Espanha. Os CCCOs em estádio inicial que sofreram progressão de doença de forma rápida foram caracterizados por ganhos nos genes $M A P K 8$ e $M K L 1$

Palavras-chave: OCCC; carcinoma de células claras de ovário; variação do número de cópias. 


\begin{abstract}
Batista, Mariana de Paiva. Molecular profile of the ovarian clear cell carcinoma and its clinical correlation in the experience of four institutions. Doctoral thesis - Post-graduation Program in Clinical Oncology, Stem Cells and Cell Therapy of the Medical School of Ribeirão Preto - University of São Paulo (FMRP-USP). Department of Clinical Medicine, Division of Clinical Oncology. 2021.
\end{abstract}

Ovarian clear cell carcinomas (OCCC) are rare, aggressive and chemo-resistant tumors. Geographical and ethnic differences in the incidence of OCCCs have been reported with higher incidence in Asiatic countries. There is a paucity of information about OCCC in Latin America (L.A.) and other countries. Here, we characterized two cohorts of 33 patients with OCCC from L.A. (24 from Brazil and 9 from Costa Rica) and a cohort of 27 patients from Spain. We detected a higher frequency of aberrant TP53 expression in the Brazilian cohort. The median overall survival (OS) was not significantly different between the cohorts. Then, patients were classified in three subgroups according to genomic landscapes in Simplex-like $(\mathrm{Sxl})(\mathrm{n}=12)$, Firestorm-like $(\mathrm{FSl})(\mathrm{n}=2)$ and Sawtooth-lixe $(\mathrm{STl})(\mathrm{n}=12)$ according to previous described by Tan et al (TAN et al., 2011) No genomic landscape was associated with outcomes. Finally, genomic analysis was expanded using the OncoScan assay. Patients with $M Y C$-amplified tumors bearing a concomitant loss of a region in chromosome 13q12-q13, which includes BRCA2 gene (MB subgroup) comprehended the longest-survivors. In contrast, non-MB patients carrying a high number (>30) of total copy number $(\mathrm{CN})$ aberrations presented the poorest survival (PS subgroup). Furthermore, amplification of the ASH1L gene was also associated with shorter OS. No difference in the distribution of genomic landscapes or of MB and PS profiles were detected between patients from the different cohorts. Initialstage OCCCs that suffered early progression were characterized by gains in MAPK 8 and MKL1 gene.

Key-words: OCCC; ovarian clear cell carcinoma; copy number variants 


\section{LISTA DE ILUSTRAÇÕES}

Figura 1 - Perfis genômicos individuais de CCCO.......................................................... 24

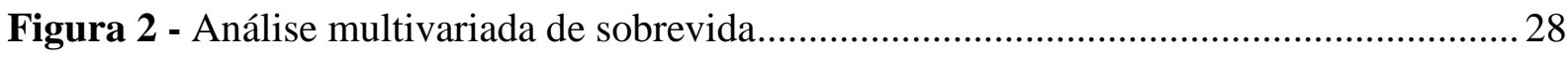

Figura 3 - Alterações no número de cópias em CCCO …................................................. 32

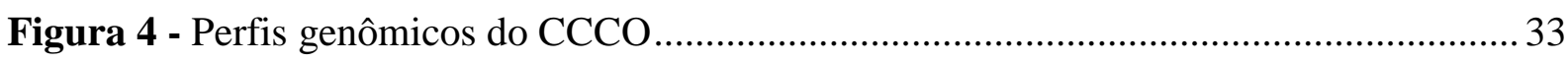

Figura 5 - Perfis genômicos de CCCO não relacionados a desfechos de sobrevida. ............... 35

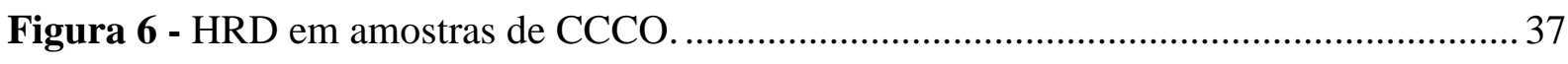

Figura 7 - Grupos de CCCO baseados em níveis de HRD-sum são associados a desfechos

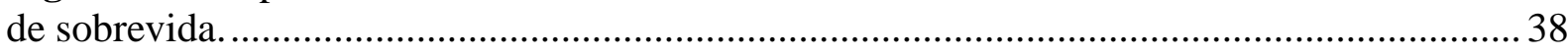

Figura 8 - Determinantes genômicos associados a desfechos de SG em CCCO. ................... 39

Figura 9 - Características dos grupos de Sobrevida Global ............................................. 40

Figura 10 - Alterações genômicas associadas a progressão de doença em estádios iniciais

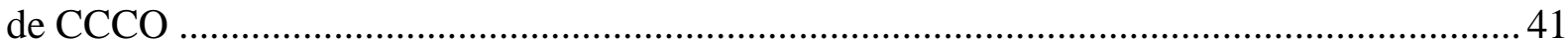

Figura 11 - Alterações genômicas em um amostra de recorrência de CCCO ......................... 47 


\section{LISTA DE TABELAS}

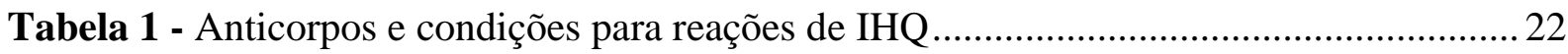

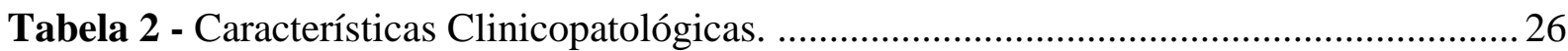

Tabela 3 - Análise univariada de CCCO............................................................................ 27

Tabela 4 - Marcadores moleculares em amostras de tumores primários de CCCO ............... 29

Tabela 5 - Associação entre status de mutação de PIK3CA em amostras de tumores

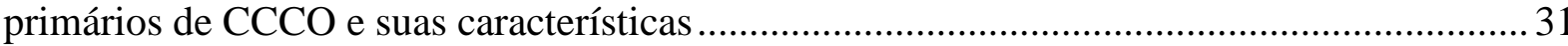




\section{LISTA DE ABREVIATURAS E SIGLAS}

ACCC A.C. Camargo Cancer Center

aCGH Hibridização Genômica Comparativa em array

ALK ALK receptor tyrosine kinase

ANC DNA Alteração no número de cópias do DNA

ARID1A At-rich interaction domain 1a

ASH1L Ash1 like histone lysine methyltransferase

BRCA1 Breast cancer gene 1

BRCA2 Breast cancer gene 2

CCCO Carcinoma de células claras de ovário

CCNE1 Cyclin e1

CDK18 Cyclin dependent kinase 18

CEO Carcinoma epitelial de ovário

CONEP Comissão Nacional de Ética em Pesquisa

EGFR Receptor do fator de crescimento epidérmico

ELK4 ETS transcription factor ELK4

FFPE Tecidos emblocados em parafina

FIGO International Federation of Gynecology and Obstetrics

FMRP-USP Faculdade de Medicina de Ribeirão Preto - Universidade de São Paulo

FS Firestorm

FS1 FS-semelhante

HE Hematoxilina e eosina

HER2 Human Epidermal growth factor Receptor-type 2

HGSC Carcinoma seroso de alto grau

HNF1B Homeobox b

HR Hazard ratio

HRD Deficiência de recombinação homóloga

HRD-LOH Perda de heterozigosidade

HRD-LST Transições de grande escala

HRD-sum Pontuação combinada de HRD

HRD-TAI Número de desbalanços teloméricos alélicos 
ICIs Inibidores de pontos de controle imunes

IHQ Imuno-histoquímica

IVO Instituto Valenciano de Oncología

LRR Razão de $\log 2$

MAPD Média dos valores absolutos de todas as diferenças pareadas

MAPK1 Mitogen-activated protein kinase 1

MAPK8 Mitogen-activated protein kinase 8

MCHR1 Melanin concentrating hormone receptor 1

MECOM Mds1 and evi1 complex locus

MKL1 Megakaryoblastic leukemia (translocation) 1

MLH1 Mutl homolog 1

MMR Proteínas do Reparo de DNA Mismatch

MRTFA Fator de Transcrição associado a Miocardina A

MSH2 Muts Homolog 2

MSH6 Muts Homolog 6

MSI Instabilidade de Microssatélites

MYC Myelocytomatosis oncogene

ndSNPQC $\quad$ SNP QC de marcadores diploides normais

PARP Polimerase poli (ADP-ribose)

PD1 Proteína de morte celular programada 1

PD-L1 Ligante da proteína de morte celular programada 1

PIK3CA Phosphatidylinositol-4,5-biphophate 3-kinase catalytic subunit alfa

PMS2 PMS1 homolog 2

PPMID Protein phosphatase, $\mathrm{mg} 2+/ \mathrm{mn} 2+$ dependent $1 \mathrm{~d}$

PPP2R1A Protein phosphatase 2 scaffold subunit aalpha

PTEN Phosphatase and tensin homologue deleted at chromosome Ten

q PCR Cadeia de polimerase quantitativa

QC Controles de qualidade

RE Receptor de estrógeno

RP Receptor de progesterona

RT-PCR Transcrição reversa em cadeia de polimerase em tempo real 
SLP Sobrevida Livre de Progressão

SNP Polimorfismo de Nucleotídeo Único

SPSS Statistical Package for Social Sciences

ST Sawtooth

STl ST-semelhante

Sx Simplex

Sxl Sx-semelhante

TEV Eventos tromboembólicos

TMA Microarranjo tecidual

TP53 Proteína supressora tumoral 53

WNT7B Wnt family member 7B

WT1 Proteína 1 do tumor de wilms

ZNF217 Zinc finger protein 217 


\section{SUMÁRIO}

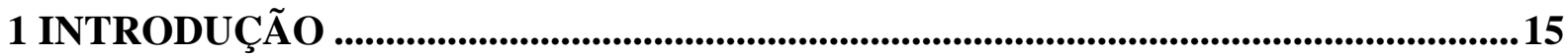

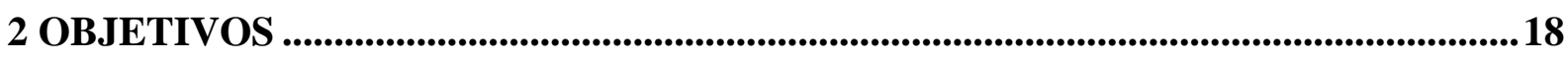

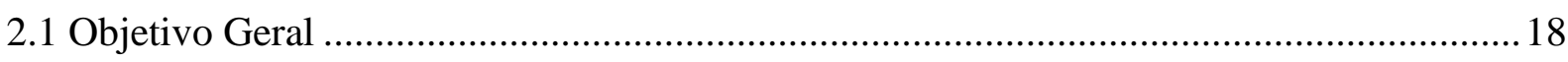

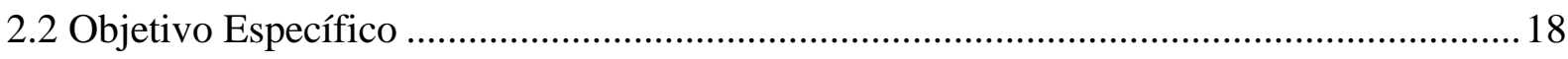

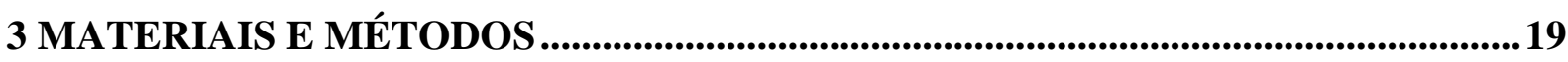

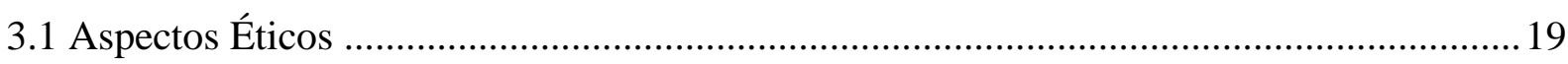

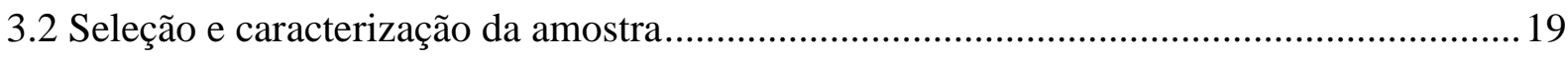

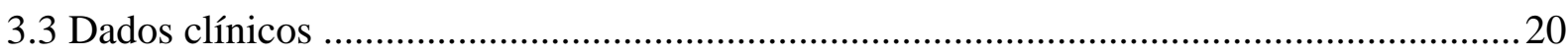

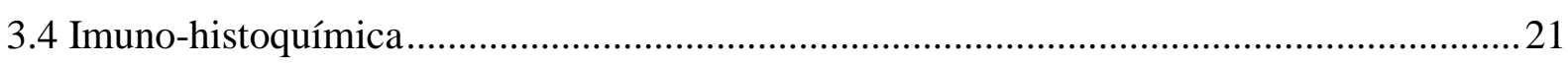

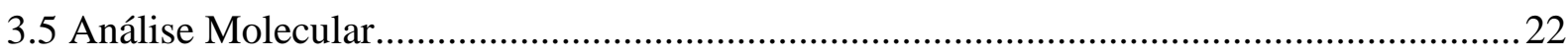

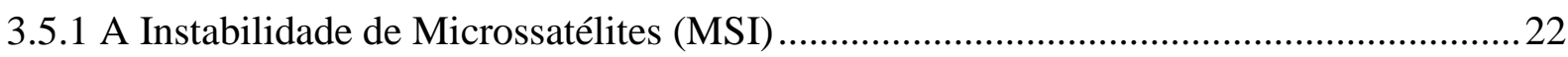

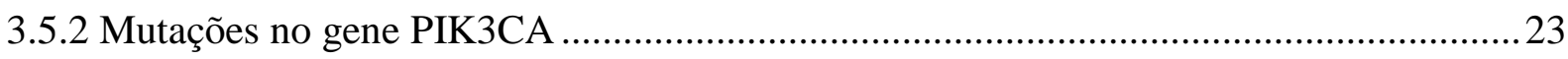

3.5.3 A análise de Polimorfismo de Nucleotídeo Único (SNP) ............................................... 23

3.5.4 O Processamento dos dados brutos (arquivo CEL) ………………………………........ 23

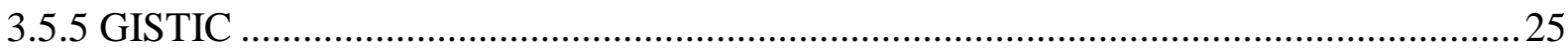

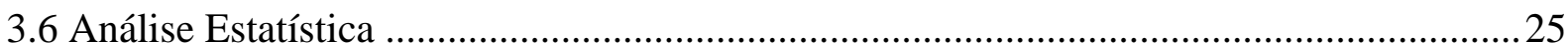

4 RESULTADOS .....................................................................................................................26

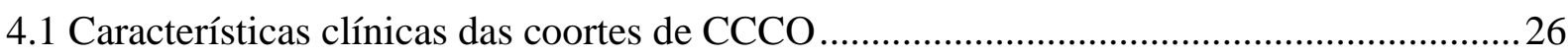

4.2 Caracterização molecular das coortes de CCCO ..............................................................2

4.3 Análise do número de cópias em todo o genoma de $\mathrm{CCCO}$............................................... 31

4.4 Padrões de alterações genômicas em CCCO...................................................................... 33

4.5 HRD está associado a perfis genômicos em CCCO …………………………………........ 36

4.6 Alterações genômicas associadas a diferentes desfechos de SG ............................................38

4.7 Alterações genômicas associadas a progressão precoce em estádios iniciais de CCCO....41

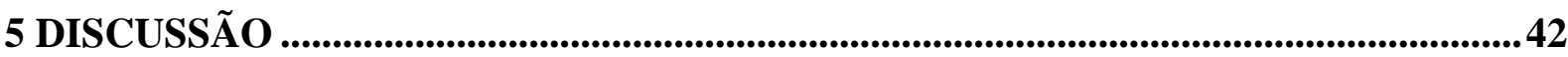

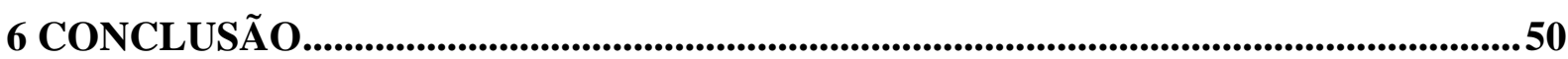

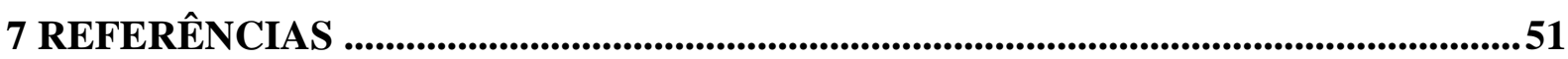

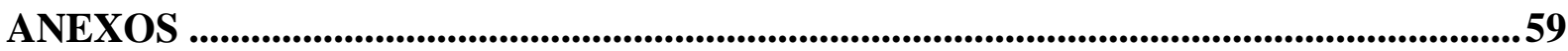




\section{INTRODUÇÃO}

O carcinoma ovariano é composto por diferentes subtipos histológicos que possuem características laboratoriais e patogênicas distintas, assim como distintos desfechos clínicos (OKAMOTO et al., 2014). Habitualmente está associado a alta letalidade e morbidade ao redor do mundo. Globalmente, cerca de trezentas mil mulheres são diagnosticadas com carcinoma de ovário todos os anos, representando cerca de $4 \%$ de todos os cânceres em mulheres (SUNG et al., 2021).

O carcinoma de células claras de ovário (CCCO) é o subtipo histológico responsável cerca de 5-25\% dos casos de carcinoma epitelial de ovário (CEO), a depender da origem geográfica. O CCCO apresenta como peculiaridade uma maior resistência ao tratamento padrão para $\mathrm{CEO}$, o qual é baseado em platina, e consequentemente um pior prognóstico dentre os subtipos de CEO (ANGLESIO et al., 2011) (SUGIYAMA, 2000). Embora o CCCO seja um subtipo raro entre os cânceres de ovário, significativas diferenças entre incidências geográficas e raciais são conhecidas (IIDA et al., 2021). A frequência relativa de casos de CCCO dentre os CEO em países asiáticos como a Corea (10,3\%) (KIM et al., 2015), Taiwan $(18,13 \%)$ (CHIANG et al., 2013), e Japão (24-25\%) (YAHATA; BANZAI; TANAKA, 2012) é mais alta que a reportada na América do Norte (12,2\%) (KÖBEL et al., 2010) e nos países europeus como Reino Unido (8\%), Finlândia (6\%) e Alemanha (2\%) (COBURN et al., 2017), (SUNG et al., 2014). Os motivos para estas diferenças ainda não foram esclarecidos, porém, Korenaga et al sugeriram que um fator genético possa ter importância na patogênese, com base na observação de que nos Estados Unidos da América (EUA) há um risco elevado de CCCO associado a etnia asiática, independentemente do local de nascimento (KORENAGA et al., 2020). A identificação dos fatores subjacentes às diferenças geográficas é essencial para o aprimoramento do diagnóstico e dos desfechos relacionados ao tratamento desta neoplasia.

Além das diferenças geográficas relevantes, as taxas objetivas de resposta à terapia convencional com platina são frequentemente mais baixas (em torno de 11\%) quando comparadas a subtipos histológicos mais quimiossensíveis, como os carcinomas serosos de alto grau de ovário (HGSC) (acima de 70\%) (SUGIYAMA, 2000) (CHAN et al., 2008). Sendo assim, pacientes portadoras de CCCO apresentam pior prognóstico em comparação a outros subtipos de CEO, especialmente quando em estádios avançados (LEE et al., 2011), (ANGLESIO et al., 2011). Clinicamente, os CCCO são mais comumente associados à endometriose (PEARCE et al., 2012), considerada um precursor direto do CCCO (ANGLESIO et al., 2015). Outra característica particular do CCCO é a maior incidência 
apresentada de eventos tromboembólicos (TEV) quando comparada a outros subtipos de CEO (DUSKA et al., 2010). O CCCO recorre predominantemente em múltiplos sítios sendo associado a altas taxas de mortalidade e curta sobrevida pós recorrência (HOGEN et al., 2019).

As alterações genéticas mais frequentes do CCCO são encontradas nos genes AT-Rich Interaction Domain 1A (ARID1A) e phosphatidylinositol-4,5-biphophate 3-kinase catalytic subunit alfa (PIK3CA) (IIDA et al., 2021). Ambas alterações frequentemente coexistem e ocorrem como um evento precoce no desenvolvimento do CCCO (YAMAMOTO et al., 2012). De fato, a coexistência de mutação em ARID1A e em PIK3CA promove a tumorigênese do CCCO em modelos animais, identificando-a como importante promotora oncogênica do CCCO (CHANDLER et al., 2015).

ARID1A é uma subunidade do complexo SWI/SNF, um complexo de remodelação de nucleossomos envolvido no desenvolvimento, diferenciação e proliferação celular, além de reparo do DNA e supressão tumoral (CHANDLER et al., 2015). Por outro lado, PIK3CA faz parte da família fosfatidilinositol-3-quinases (PI3Ks) que desempenha um importante papel celular de proliferação, aderência, transformação e sobrevivência através da via de sinalização PI3K\AKT (PECTASIDES et al., 2006). A amplificação da região cromossômica que contém o gene PIK3CA é associado ao aumento da expressão proteica e atividade da quinase-PI3. Esta amplificação é descrita em aproximadamente $40 \%$ dos casos de CCCO enquanto nos carcinomas serosos de ovário é observada em 10\% dos casos (PECTASIDES et al., 2006). Além disso, a observação que diversos receptores de tirosina-quinase são superexpressos em CCCO sugere que a via de sinalização RTK-PI3KImTOR esteja amplamente ativada nestes tumores (CHEAIB, 2015). A interação do complexo SWI-SNF e a via PI3K foi sugerida por Wiegand et al através da observação de que a perda de ARID1A correlaciona-se com o aumento da fosforilação de AKT, independentemente da expressão de PI3K e do gene Phosphatase and tensin homologue deleted at chromosome Ten (PTEN) (WIEGAND et al., 2010).

Outras alterações genômicas e cromossômicas recorrentes envolvidas na proliferação celular foram descritas em CCCO. Mutações nos genes Protein Phosphatase 2 Scaffold Subunit Aalpha (PPP2R1A), amplificação de 17q21-24, Protein Phosphatase, Mg2+/Mn2+ Dependent 1D (PPMID) e Cyclin E1 (CCNE1) fazem parte de um cenário genômico complexo que poderia fundamentar casos de CCCO mesmo na ausência de mutações em ARID1A e PIK3CA (CHANDLER et al., 2015). 
Outros importantes marcadores moleculares presentes em CCCO são usados para diagnóstico diferencial entre outros CEO e incluem: a presença da proteína Homeobox B (HNF1B) e a ausência da expressão da proteína 1 do Tumor de Wilms (WT1), do receptor de estrógeno (RE) e do receptor de progesterona (RP) (MARKS, E. I., BROWN, V. S. AND DIZON, 2020). Ao contrário do carcinoma seroso de alto grau de ovário, o CCCO comumente expressa a proteína supressora tumoral 53 (TP53) na sua forma selvagem e apresenta uma frequência mais baixa de mutações em Breast Cancer gene 1 (BRCA1) e Breast Cancer gene 2 (BRCA2), dessa forma a instabilidade genômica observada nestes casos é mais baixa quando comparada aquela no carcinoma seroso de alto grau de ovário (KHALIQUE et al., 2020).

Diversos estudos publicados analisaram o padrão de alterações genômicas entre coortes de CCCO de diferentes origens étnicas e geográficas (UEHARA et al., 2015) (OKAMOTO et al., 2015) (TAN et al., 2011) (KUO et al., 2010). Notavelmente, duas das mais frequentes alterações no número de cópias de DNA (ANC DNA) em CCCO, como exemplo a amplificação das regiões dos cromossomos 8q e 20q13.2 (incluindo o oncogene Zinc Finger Protein 217 - ZNF217), apresentam prevalência distinta entre diferentes origens geográficas. Conforme observado em análise de hibridização genômica comparativa de alta resolução (aCGH) por Okamoto et al, ambas regiões se apresentaram amplificadas de forma significativamente mais frequente em casos japoneses que em coreanos e alemães (OKAMOTO et al., 2015). Atualmente, perfis genômicos amplos avaliando alterações no número de cópias nos CCCO em países de origem latina ainda não foram realizados. Dentre os países latinos, o Brasil apresenta uma das mais baixas frequências de CCCO, estimada entre 1-2\% dos CEO (COBURN et al., 2017) (SUNG et al., 2014). Por outro lado, o CCCO compreende 18,8\% dos CEO na Espanha, representando uma frequência mais alta entre os países europeus (SUNG et al., 2014). Neste estudo, buscamos definir alterações de perfis genômicos no CCCO observadas em dois países da A.L., a saber Brasil e Costa Rica. Considerando que as variações metodológicas poderiam influenciar nossas conclusões, incluimos também amostras de pacientes da Espanha. Dados clínicos e moleculares foram integrados para expor determinantes moleculares bem como possíveis biomarcadores e peculiaridades desta pouco estudada população de pacientes de CCCO. Tais informações serão de grande importância para subsidiar o desenvolvimento de novas estratégias efetivas de tratamento. 


\section{OBJETIVOS}

\subsection{Objetivo Geral}

O objetivo geral deste estudo foi identificar as alterações genômicas, determinar as principais características clínicas e laboratoriais, bem como estudar o desfecho do tratamento de pacientes com CCCO diagnosticadas e tratadas em instituições do Brasil, Costa Rica e Espanha.

\subsection{Objetivo Específico}

1. Avaliar a expressão de ARID1A, HNF1B, PTEN, MutL homolog 1 (MLH1), MutS Homolog 2 (MSH2), MutS Homolog 6 (MSH6), PMS1 homolog 2 (PMS2), receptores de estrógeno, receptores de progesterona e WT1, por meio da técnica de imunohistoquímica.

2. Avaliar a presença de mutações no gene PIK3CA e de instabilidade de microssatélites (MSI).

3. Detectar e quantificar alterações no número de cópias do DNA em amostras tumorais de CCCO.

4. Avaliar características clínicas como: estádio clínico, endometriose, idade ao diagnóstico, eventos tromboembólicos, sensibilidade a platina e origem asiática ou não.

5. Correlacionar os dados citados às sobrevidas global e livre de recorrência. 


\section{MATERIAIS E MÉTODOS}

\subsection{Aspectos Éticos}

Este projeto foi aprovado pela Comissão Nacional de Ética em Pesquisa (CONEP) (Parecer 2.630.745) (ANEXOS) e pelos comitês regionais das instituições envolvidas: Comitê de Ética em Pesquisa Envolvendo Seres Humanos - Faculdade de Medicina de Ribeirão Preto - Universidade de São Paulo (FMRP-USP) (Parecer HCRP nº 1.187.347, Atualizações: 2.485.363, ), A.C. Camargo Center (Parecer no 3.759.823), Hospital Mexico em Costa Rica e Instituto Valenciano de Oncología na Espanha.

Esta pesquisa não acarretou exposição dos pacientes a quaisquer riscos, pois se trata de estudo envolvendo coleta retrospectiva de informações clínicas existentes em prontuários e análises moleculares e imunohistoquímicas a partir de amostras tumorais parafinadas. As amostras elegidas por suas respectivas instituições fizeram parte de um Biorrepositório em comum entre os quatro centros participantes, mantido durante a realização do projeto (Acordos para Biorrepositório). Seu armazenamento e conservação são de responsabilidade dos centros promotores das análises estipuladas enquanto realizadas. É também de responsabilidade dos participantes a devolução do material biológico remanescente até a chegada em seu sítio de origem. Evidenciamos aqui que caso ocorra a dissolução da parceria os participantes se responsabilizam pela partilha e destinação dos dados e materiais armazenados aos seus centros de origem.

Ressalta-se que não houve intervenção direta ao paciente, assim como benefícios extras como remuneração para os sujeitos participantes. Os resultados poderão contribuir para o entendimento da evolução e tratamento do CCCO, sendo estes divulgados apenas em revistas científicas, respeitando-se o sigilo da identidade dos pacientes envolvidos.

\subsection{Seleção e caracterização da amostra}

Pacientes com idade maior que 18 anos diagnosticadas com CCCO entre os anos de 2000 e 2015 foram recrutadas por suas respectivas instituições em três diferentes países. Um total de 60 pacientes foram incluídas com a seguinte distribuição geográfica: 7 casos provindos do Hospital das Clínicas da Faculdade de Medicina de Ribeirão Preto (HCRP) - Brasil; 17 casos provindos do A.C. Camargo Cancer Center (ACCCC) - Brasil; 9 casos provindos do Hospital Mexico - Costa Rica e 27 casos do Instituto Valenciano de Oncología (IVO). 
Dentre os casos descritos foram obtidas cinquenta e sete amostras oriundas de tumores primários no momento do diagnóstico, enquanto quatro amostras foram obtidas de metástases em cenário de recorrência de doença. Um caso apresentava amostra de seu tumor primário e de sua respectiva metástase em cenário de recorrência.Todas as amostras foram revisadas por 2 patologistas para a confirmação do diagnóstico histológico de carcinoma puro de células claras de ovário.

Pacientes vivas e em seguimento em suas instituições seriam abordadas em consulta médica pelos respectivos investigadores principais designados para explicação do estudo e, em havendo concordância, assinatura do Termo de Consentimento Livre e Esclarecido (ANEXO). Frente a doença de alta letalidade, foi solicitada e aprovada pelos respectivos comitês de ética a isenção de termo de consentimento para as pacientes já falecidas ou com perda de seguimento.

Critérios de inclusão dos pacientes na pesquisa

1. Pacientes adultas (idade maior ou igual a 18 anos) com diagnóstico histopatológico de CCCO com confirmação por revisão centralizada realizada em Madri, por patologista com experiência em tumores ginecológicos.

2. Possuir material biológico tumoral armazenado em blocos de parafina com qualidade suficiente para as análises

3. Apresentar disponibilidade de dados clínicos

\subsection{Dados clínicos}

Os dados clínicos obtidos em revisão de prontuários compreenderam o estádio clínico no momento do diagnóstico (definido pelo sistema de estadiamento de ovário - International Federation of Gynecology and Obstetrics - FIGO 2014 (MUTCH; PRAT, 2014)), bem como datas de diagnóstico, progressão, óbito e último contato. A presença de endometriose, eventos tromboembólicos e metástases ósseas também foram registradas para caracterização das populações. Quanto ao desfecho clínico, foram analisadas as variáveis:

1. Sobrevida Global Específica (SG), definida como o tempo decorrido da data do diagnóstico do tumor por biópsia até a data de óbito decorrente da evolução/progressão do CCCO.

2. Sobrevida Livre de Progressão (SLP), definida como o tempo decorrido da data do diagnóstico do tumor até a data da progressão da doença ou óbito. 
3. Sensibilidade a platina após tratamento adjuvante foi observada de acordo com o critério histórico, reiterado pela definição estabelecida na Quarta Conferência de Câncer de Ovário. Recorrências sensíveis a platina são assim definidas quando ocorrem em período igual ao maior a seis meses após o fim do tratamento com platina, já as recorrências resistentes a platina ocorrem em intervalo de tempo menor que seis meses após o fim do tratamento com platina (STUART et al., 2011).

\subsection{Imuno-histoquímica}

Tecidos emblocados em parafina à 10\% (FFPE) foram processados de forma rotineira e tingidos com hematoxilina e eosina (HE). As regiões tumorais foram marcadas nas lâminas de HE assim como em suas regiões correspondentes nos blocos de parafina. Fragmentos de um milímetro foram retirados de cada bloco doador e transferidos para um bloco recipiente (MiniCore, Alphelys, Plaisir, France). Uma amostra foi obtida por bloco, fornecendo uma representação de 2 pontos por caso em um microarranjo tecidual (TMA).

As análises imuno-histoquímicas foram realizadas em cortes do TMA ou diretamente em cortes dos FFPE, cortes de 4- $\mu$ m de espessura foram processados.

A recuperação antigênica foi realizada através da incubação em 1.2 atm por 3 minutos em 10mmol/L de tampão de citrato ( $\mathrm{pH}$ 6.0). Os anticorpos primários e suas condições específicas estão listados na Tabela 1. O método LSAB (Dako) foi desenvolvido, seguido de revelação utilizando 3,3'-diaminobenzidina, de acordo com os protocolos convencionais. A imunomarcação nuclear de qualquer intensidade foi considerada positiva para a avaliação de ARID1A, HNF1B, PTEN, MLH1, MSH2, MSH6, PMS2. Com relação a análise de TP53, a imunomarcação foi considerada normal quando atingisse de 1-70\% dos núcleos celulares analisados por amostra e aberrante quando ausente ou presente em mais de $70 \%$ das células analisadas. A imunomarcação nuclear foi considerada positiva para WT1 quando mais de $50 \%$ das células tumorais o marcassem e positiva para expressão de receptores de estrógeno $(\mathrm{RE})$ e receptores de progesterona (RP) quando mais de $5 \%$ das células fosse corado. 
Tabela 1 - Anticorpos e condições para reações de IHQ.

\begin{tabular}{lllllc}
\hline Anticorpos & Fornecedor & Catálogo \# & Diluição & Recuperação de antígeno & Incubação (min) \\
\hline HNF1B & Sigma & & Puro $1 / 100$ & baixo $\mathrm{pH}, 97^{\circ} \mathrm{C}, 30 \mathrm{~min}$ & 30 \\
WT1 & DAKO & Clone GF-H2 & Pré diluído & alto $\mathrm{pH}, 97^{\circ} \mathrm{C}, 30 \mathrm{~min}$ & 18 \\
ER & DAKO & Clone FP1 & Pré diluído & alto $\mathrm{pH}, 97^{\circ} \mathrm{C}, 30 \mathrm{~min}$ & 12.5 \\
PR & DAKO & Clone PgR 1294 & Pré diluído & alto $\mathrm{pH}, 97^{\circ} \mathrm{C}, 30 \mathrm{~min}$ & 25 \\
ARID1A-L & Abcam & EPR13501-73 & puro $1 / 100$ & Baixo $\mathrm{pH}, 97^{\circ} \mathrm{C}, 30$ min & 20 \\
TP53 & DAKO & Clone DO-7 & Pré diluído & alto $\mathrm{pH}, 97^{\circ} \mathrm{C}, 30$ min & 25 \\
PTEN & DAKO & Clone $6 \mathrm{H} 2.1$ & Puro $1 / 100$ & Alto $\mathrm{pH}, 97^{\circ} \mathrm{C}, 30$ min & 20 \\
MLH1 & DAKO & Clone ES05 & Pré diluído & alto $\mathrm{pH}, 97^{\circ} \mathrm{C}, 30$ min & 35 \\
MSH2 & DAKO & Clone FE11 & Pré diluído & alto $\mathrm{pH}, 97^{\circ} \mathrm{C}, 30$ min & 20 \\
MSH6 & DAKO & Clone EP49 & Pré diluído & alto $\mathrm{pH}, 97^{\circ} \mathrm{C}, 30$ min & 20 \\
PMS2 & DAKO & Clone EP51 & Pré diluído & Alto $\mathrm{pH}, 97^{\circ} \mathrm{C}, 30$ min & 40 \\
\hline
\end{tabular}

\subsection{Análise Molecular}

A extração de DNA foi realizada utilizando três cortes de $20 \mu \mathrm{m}$ de espessura das amostras em FFPE e o kit QIAmp DNA FFPE Tissue (Qiagen). A concentração final de DNA foi medida por espectrofotometria com Nanodrop ND-100 (ThermoFisher).

A amplificação de 2-3 ng de DNA foi realizada usando o Kit de reação em cadeia de polimerase (PCR), Type-it Mutation Detect PCR (Qiagen), em uma termocicladora (Verti, Ampplied Biosystem). As condições necessárias para PCR eram consecutivamente: $95^{\mathrm{a}} \mathrm{C}$ por 5 min para desnaturação, 35 ciclos a $95^{\mathrm{a}} \mathrm{C}$ por $30 \mathrm{~min}, 1,5 \mathrm{~min}$ a $60^{\circ} \mathrm{C}$ e $30 \mathrm{~min}$ a $72^{\circ} \mathrm{C}$ com uma finalização de $10 \mathrm{~min}$ a $68^{\circ} \mathrm{C}$. Os produtos obtidos no método de PCR foram desnaturados durante a $5 \mathrm{~min}$ com formamida a $95^{\circ} \mathrm{C}$ e então introduzidas no Applied Biosystem $3130 \mathrm{XL} /$ Genetic Analyzer para a realização de eletroforese capilar e análise fragmentar com o Gene Mapper Software v.4 (Applied Biosystems).

\subsubsection{A Instabilidade de Microssatélites (MSI)}

Foi analisada utilizando um painel de 5 biomarcadores mononucleotídeos (BAT-25, BAT-26, NR-21, NR-24 e NR-27) cada um registrado com um fluoróforo específico; FAM, HEX e NED. 


\subsubsection{Mutações no gene PIK3CA}

Foram detectadas por PCR em tempo real, utilizando a Plataforma COBAS com kit de detecção específico para esta mutação, Cobas® PIK3CA Mutation Test (Roche Molecular Systems Inc).

\subsubsection{A análise de Polimorfismo de Nucleotídeo Único (SNP)}

Foi realizada a partir de cortes de $10 \mu \mathrm{m}$ de FFPE desparafinizados. O ácido desoxirribonucléico (DNA) presente nestes cortes de tecidos foi extraído utilizando o Kit QIAamp DNA FFPE Tissue (Qiagen, Valencia, CA). O DNA foi avaliado e quantificado por dois métodos distintos: o espectofotômetro Denovix ${ }^{\mathrm{TM}}$ e o fluorômetro Quantus ${ }^{\mathrm{TM}}$, conforme as orientações do fabricante. Dentre 59 amostras de CCCO, 26 amostras proveram DNA em quantidade e qualidade suficientes para a realização da análise de SNP utilizando a plataforma OncoScan® FFPE.

A análise de SNP foi realizada de acordo com as recomendações protocolares utilizando 80ng de DNA genômico. Após a hibridização em 18h, os microarranjos foram tingidos, lavados e posteriormente carregados no scanner GeneChip® 3000 7G (Thermo Fisher Scientific/Affymetrix). Arquivos CEL foram criados pelo software Affymetrix Gene Chip Comand Console ${ }^{\circledR}$ (v. 4.0) e processados pelo software OncoScan Console (v. 1.3) resultando em arquivos OSCHP files e QC métricas.

\subsubsection{O Processamento dos dados brutos (arquivo CEL)}

Foi realizado pelo Affymetrix OncoScan Console (Thermo) utilizando a análise do produto extraído do FFPE com NA33 (FFPPE.na33.r1) como um modelo de referência controle e aplicou o algoritmo TuScan. Dois controles de qualidade (QC) foram providos pelo software, o MAPD (média dos valores absolutos de todas as diferenças pareadas) e o ndSNPQC (SNP QC de marcadores diploides normais), 20 (76.9\%) e 13 amostras (50\%) das 26 encontravam-se dentre seus limites, respectivamente. Dado que estes marcadores de controle de qualidade foram desenvolvidos para genomas diploides normais e que amostras tumorais heterogêneas não concordantes com estes padrões sejam esperadas, utilizamos todo a informação obtida em nossas análises. Duas amostras precisaram de re-centralização (Occ15 e Occ23) e quatro amostras (Occ9, Occ23, Occ16 e Occ36), em que basicamente todo o 
genoma era poliploide, foram re-centralizadas para aproximação com uma versão diploide para viabilizar análise posterior. Os arquivos segmentados obtidos no OncoScan console foram utilizados para a análise descrita.

O algoritmo ASCAT foi utilizado para estimar a ploidia tumoral, calculando o número de cópias e segmentação específica do alelo. O pacote ASCAT para R foi utilizado com os seguintes parâmetros: ascat.predictGermlineGenotypes(platform = "AffyOncoScan") $\mathrm{e}$ ascat.runAscat $($ gamma $=0.9)$. LRR individuais são apresentados nas Figura 1. A estimativa da presença de deficiência de recombinação homóloga (HRD): perda de heterozigosidade (HRD-LOH); transições de grande escala (HRD-LST); número de desbalanços teloméricos alélicos (HRD-TAI) e sua respectiva pontuação combinada (HRD-sum) foi determinada pelo algoritmo ASCAT utilizando o pacote de dados scarHRD para R.

Figura 1 - Perfis genômicos individuais de CCCO.

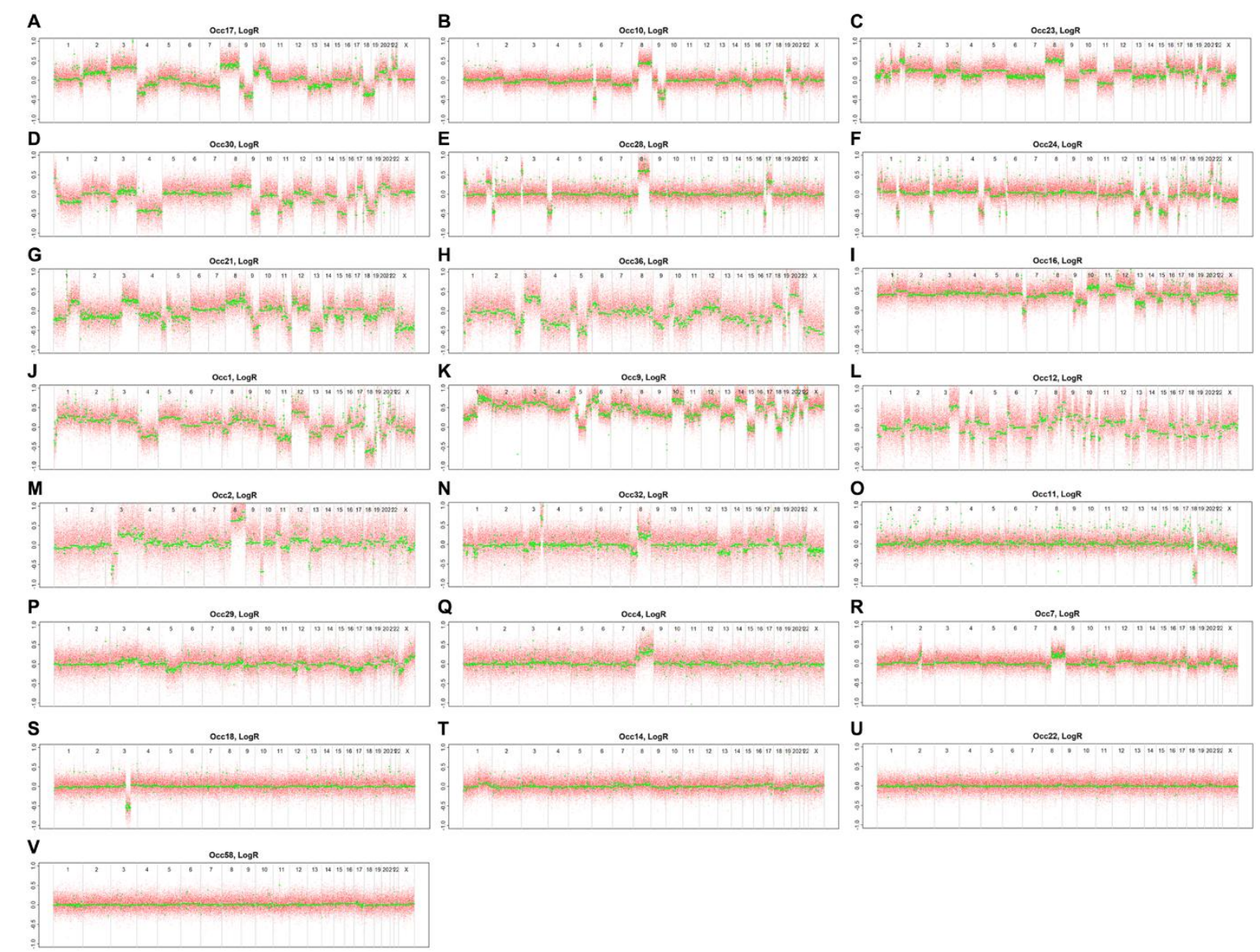

(A-V) Dados segmentados de amostras de tumores primários de CCCO foram usados para análise no algoritmo ASCAT. Os gráficos apresentam perfis individuais em razão de $\log 2$. Perfis adicionais estão demonstrados na Figura1 e Figura 11. 


\subsubsection{GISTIC}

As informações obtidas de forma segmentada foram inseridas no programa GISTIC2.0 (v2.0.23) (MERMEL et al., 2011) em GenePattern. As análises no programa GenePattern (REICH et al., 2006) foram realizadas com requisitos padrão (intervalo de confiança=0.90; qlimite $=0.25$; limite de amplificações e deleções $=0.1$; limite de duração focal $=0.50$ ) e utilizamos o Human_Hg19.mat como referência para arquivo gênico. O arquivo CNV foi obtido de Broad Institute (CNV.hg19.bypos.111213.txt).

\subsection{Análise Estatística}

A análise estatística foi realizada utilizando-se o programa Statistical Package for Social Sciences (SPSS) (Versão 22.0, SPSS, Inc., Chicago, IL). Testes de Chi-quadrado foram utilizados para análise de variáveis categóricas enquanto o Teste paramétrico de TStudent analisou as variáveis contínuas. O método não paramétrico de Kaplan-Meier foi utilizado para estimar sobrevidas (global e livre progressão). As sobrevidas estimadas foram analisadas de forma multivariável (dados clínicos e perfis genômicos) pelo modelo de riscos proporcionais de Cox (LEE; WANG, 2003). As análises multivariáveis incluíram variáveis significativas em análises uni variadas. Este modelo calcula o Hazard Ratio (HR) que fornece o quanto uma categoria tem de risco de vir a óbito (no caso de sobrevida global, por exemplo) em relação à outra. $\mathrm{O}$ menor valor de $\alpha$ (nível de significância) escolhido para rejeitar a hipótese nula foi de 0,05 . A perda de seguimento ou a ausência da informação foi considerada como dado censurado. O tipo de censura usado neste estudo foi a censura tipo I, na qual os pacientes foram incluídos em tempos diferentes durante o período de acompanhamento. 


\section{RESULTADOS}

\subsection{Características clínicas das coortes de CCCO}

Neste estudo analisamos três diferentes coortes de pacientes diagnosticadas com CCCO, obtidas de instituições localizadas em três diferentes países: Espanha (27 casos), Brasil (24 casos) e Costa Rica (9 casos) (Tabela 2).

Tabela 2 - Características Clinicopatológicas.

\begin{tabular}{|c|c|c|c|c|}
\hline \multirow{2}{*}{ Parâmetros } & \multirow{2}{*}{ Total } & \multicolumn{3}{|c|}{ Coorte } \\
\hline & & Brasil & Costa Rica & Espanha \\
\hline Número de caos & 60 & 24 & 9 & 27 \\
\hline Idade ao diagnóstico, anos (variação) & $50(29-75)$ & $53(29-75)$ & $48(36-70)$ & $48(31-74)$ \\
\hline Asiáticas, n (\%) & $3(5)$ & $3(13)$ & $0(0)$ & $0(0)$ \\
\hline \multicolumn{5}{|l|}{ Estádio FIGO, n (\%) } \\
\hline Iniciais (I/II) & $39(65)$ & $15(63)$ & $6(67)$ & $18(67)$ \\
\hline III & $17(28)$ & $8(33)$ & $2(22)$ & $7(26)$ \\
\hline IV & $4(7)$ & $1(4)$ & $1(11)$ & $2(7)$ \\
\hline Endometriose, n (\%) & $16(27)$ & $7(29)$ & $1(11)$ & $8(30)$ \\
\hline TEVs, n (\%) & $14(23)$ & $8(33)$ & $1(11)$ & $5(19)$ \\
\hline \multicolumn{5}{|l|}{ Sensibilidade à platina, n (\%) } \\
\hline sensível & $35(66)$ & $12(60)$ & $6(75)$ & $17(68)$ \\
\hline resistente & $18(34)$ & $8(40)$ & $2(25)$ & $8(32)$ \\
\hline desconhecido & 7 & 4 & 1 & 2 \\
\hline Progressão, n (\%) & $36(60)$ & $15(63)$ & $3(33)$ & $18(67)$ \\
\hline \multicolumn{5}{|l|}{ Desfecho, n (\%) } \\
\hline Vivo & $32(53)$ & $11(46)$ & $6(67)$ & $15(56)$ \\
\hline Óbito & $28(47)$ & $13(54)$ & $3(33)$ & $12(44)$ \\
\hline $\begin{array}{l}\text { Seguimento mediano, meses } \\
\quad \text { (faixa) }\end{array}$ & $\begin{array}{l}36.3 \\
(0.43-210.6)\end{array}$ & $\begin{array}{l}39.7 \\
(0.43-123.7)\end{array}$ & $\begin{array}{l}15.6 \\
(3.1-41.0)\end{array}$ & $\begin{array}{l}36.3 \\
(1.1-210.6)\end{array}$ \\
\hline
\end{tabular}

Dentre toda a amostra, 3 pacientes (13\%) do ACCCC eram de origem asiática. O ACCC está localizado na cidade de São Paulo, local que abriga uma das maiores comunidades japonesas do mundo, justificando a identificação dessas pacientes (IWASAKI et al., 2008). A respeito das três diferentes coortes, mais de $60 \%$ dos casos foram diagnosticados em estádios iniciais, FIGO I e II; cerca de $28 \%$ em estádio III e cerca de $7 \%$ estádio IV. Endometriose foi observada em cerca 
de $30 \%$ das pacientes brasileiras e espanholas e em torno de $27 \%$ das pacientes de toda a amostra. Enquanto $88 \%$ das pacientes com endometriose foram diagnosticadas em estádios iniciais, somente $57 \%$ das pacientes não portadoras de endometriose encontravam-se nesses estádios ao diagnóstico. (valor de $P=0.0342$; teste exato de Fisher). Embora não significativa, observou-se uma diferença entre a ocorrência de eventos tromboembólicos no Brasil (33\% dos casos) e na Espanha (19\% dos casos), dentre as coortes combinadas 33\% das pacientes apresentou estes eventos em qualquer momento do seguimento. A sensibilidade ao esquema de quimioterapia baseada em platina ocorreu em ao menos $60 \%$ das pacientes de toda a amostra.

A análise univariada de sobrevida global indicou que estádios avançados (FIGO III ou IV), platino resistência ou eventos tromboembólicos (TEV) estavam associados ao aumento do risco de morte (Tabela 3).

Tabela 3 - Análise univariada de CCCO.

\begin{tabular}{|c|c|c|c|c|c|}
\hline & Parâmetros & n & HR & $95 \% \mathrm{CI}$ & valor-P \\
\hline \multicolumn{6}{|c|}{ SG } \\
\hline \multicolumn{6}{|c|}{ Estádio Figo } \\
\hline & avançado (III/IV) & 21 & 5.803 & $2.608-12.91$ & $1.64 \mathrm{e}-05 * * *$ \\
\hline & inicial (I/II) & 39 & 1 & & \\
\hline & \multicolumn{5}{|l|}{ Platino } \\
\hline & resistência & 35 & 21.09 & $7.338-60.61$ & $1.51 \mathrm{e}-08 * * *$ \\
\hline & sensibilidade & 18 & 1 & & \\
\hline & \multicolumn{5}{|l|}{ Endometriose } \\
\hline & $\operatorname{sim}$ & 16 & 0.5675 & $0.2155-1.494$ & 0.252 \\
\hline & não & 44 & 1 & & \\
\hline & \multicolumn{5}{|l|}{ TEVs } \\
\hline & Sim & 13 & 2.932 & $1.328-6.475$ & $0.00777 * *$ \\
\hline & não & 47 & 1 & & \\
\hline \multicolumn{6}{|c|}{ SLP } \\
\hline & \multicolumn{5}{|l|}{ Estádio Figo } \\
\hline & avançado (III/IV) & 21 & 6.816 & $3.3-14.08$ & $2.16 \mathrm{e}-07 * * *$ \\
\hline & inicial (I/II) & 39 & 1 & & \\
\hline & \multicolumn{5}{|l|}{ Endometriose } \\
\hline & Sim & 16 & 0.422 & $0.1746-1.02$ & 0.0554 \\
\hline & Não & 44 & 1 & & \\
\hline & \multicolumn{5}{|l|}{ TEVs } \\
\hline & Sim & 13 & 2.044 & $0.9983-4.183$ & 0.0505 \\
\hline & Não & 47 & 1 & & \\
\hline
\end{tabular}


Por outro lado, análise multivariada revelou que platino-resistência seria a principal variável dentre elas seguida da ocorrência de TEV (Figura 2). No caso da análise de sobrevida livre de progressão, o estádio avançado está associado ao aumento do risco de recorrência de doença, porém não caracterizou um fator prognóstico independente. A ocorrência de TEV apresentou uma associação marginal com o aumento de risco de recorrência. (Tabela 3).

Figura 2 - Análise multivariada de sobrevida.

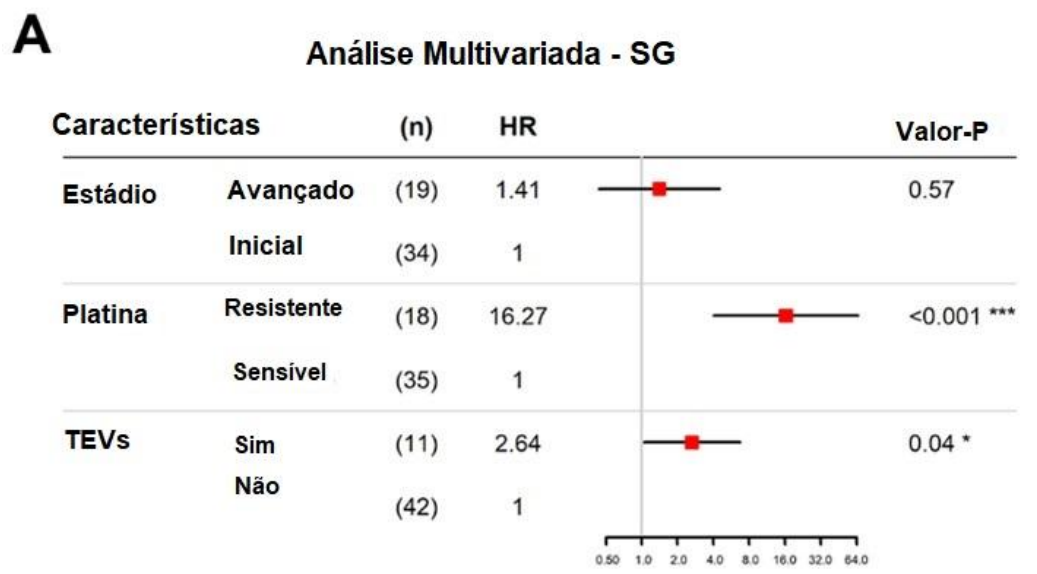

B

Análise Multivariada - SLP

\begin{tabular}{|c|c|c|c|c|c|}
\hline \multicolumn{2}{|c|}{ Características } & \multirow{2}{*}{$\begin{array}{l}\text { (n) } \\
(21)\end{array}$} & \multicolumn{2}{|l|}{ HR } & \multirow{2}{*}{$\frac{\text { Valor-P }}{71 \mathrm{e}-07^{\text {***}}}$} \\
\hline Estádio & Avançado & & 7.06 & $\longrightarrow$ & \\
\hline & Inicial & (39) & 1 & & \\
\hline \multirow[t]{2}{*}{ TEVs } & Sim & (16) & 2.32 & $\longrightarrow$ & 0.0301 * \\
\hline & Não & (44) & 1 & & \\
\hline \multirow[t]{2}{*}{ Endometriose } & Sim & (14) & 0.83 & $\longrightarrow$ & 0.6943 \\
\hline & Não & (46) & 1 & & \\
\hline
\end{tabular}

Análise Multivariada de (A) SG e (B) SLP, usando como parâmetros um valor de P <0,06 na análise univariada (Tabela 3) como covariáveis.

\subsection{Caracterização molecular das coortes de CCCO}

O CCCO caracteristicamente apresenta expressão positiva da proteína HNF1B (KATO; SASOU; MOTOYAMA, 2006). A avaliação de toda a coorte evidenciou expressão de HNF1B em cerca de $90 \%$ dos casos, sendo a coorte de Costa Rica inteiramente positiva 
nesta análise (Tabela 4). Embora de forma não significativa, a prevalência da expressão positiva de HNF1B foi diferente entre as coortes brasileiras (80\% dos casos) e espanhola (95\% dos casos). A perda de expressão da proteína ARID1A é outra alteração molecular frequente no CCCO. Utilizando a técnica de imuno-histoquímica observamos a ausência de expressão de ARID1A em cerca de $29 \%$ dos casos, fato concordante com as frequências já relatadas em outras populações, 15-46\%. (WIEGAND et al., 2010).

Tabela 4 - Marcadores moleculares em amostras de tumores primários de CCCO.

\begin{tabular}{|c|c|c|c|c|c|}
\hline \multirow[b]{2}{*}{ Marcador molecular } & \multirow[b]{2}{*}{ Método } & \multirow[b]{2}{*}{ Total } & \multicolumn{3}{|c|}{ Coorte } \\
\hline & & & Brasil & Costa Rica & Espanha \\
\hline Expressão HNF1B, n (\%) & IHQ & & & & \\
\hline Positivo & & $43(90)$ & $16(80)$ & $7(100)$ & $20(95)$ \\
\hline Negativo & & $5(10)$ & $4(20)$ & $0(0)$ & $1(5)$ \\
\hline Desconhecido & & 9 & 1 & 2 & 6 \\
\hline Expressão WT1, n (\%) & IHQ & & & & \\
\hline Positivo & & $5(9)$ & $3(14)$ & $1(12)$ & $1(4)$ \\
\hline Negativo & & $51(91)$ & $18(86)$ & $7(88)$ & $26(96)$ \\
\hline Desconhecido & & 1 & 0 & 1 & 0 \\
\hline Expressão RE, n (\%) & IHQ & & & & \\
\hline Positivo & & $4(7)$ & $2(10)$ & $0(0)$ & $2(7)$ \\
\hline Negativo & & $53(93)$ & $19(90)$ & $9(100)$ & $25(93)$ \\
\hline Expressão RP, n (\%) & IHQ & & & & \\
\hline Positivo & & $1(2)$ & $0(0)$ & $0(0)$ & $1(4)$ \\
\hline Negativo & & $56(98)$ & $21(100)$ & $9(100)$ & $26(96)$ \\
\hline Expressão TP53, n (\%) & IHQ & & & & \\
\hline Aberrante & & $20(36)$ & $13(62)$ & $3(37)$ & $4(15)$ \\
\hline Normal & & $36(64)$ & $8(38)$ & $5(63)$ & $23(85)$ \\
\hline Desconhecido & & 1 & 0 & 1 & 0 \\
\hline Expressão ARID1A, n (\%) & IHQ & & & & \\
\hline Positivo & & $35(71)$ & $14(74)$ & $7(87)$ & $14(64)$ \\
\hline Negativo & & $14(29)$ & $5(26)$ & $1(13)$ & $8(36)$ \\
\hline Desconhecido & & 8 & 2 & 1 & 5 \\
\hline PIK3CA mutação, n (\%) & PCR temp & & & & \\
\hline Mutado & & $14(30)$ & $4(25)$ & $3(37)$ & $7(32)$ \\
\hline Selvagem & & $32(70)$ & $12(75)$ & $5(63)$ & $15(68)$ \\
\hline Desconhecido & & 11 & 5 & 1 & 5 \\
\hline
\end{tabular}


A ausência de expressão da proteína WT1 é outro marcador molecular usado para o diagnóstico diferencial entre o $\mathrm{CCCO}$ e os outros subtipos histológicos de carcinomas epiteliais de ovário. De fato, a expressão de WT1 não foi detectada em 91\% dos casos, condizente com o diagnóstico histológico de CCCO. Além disso, as expressões positivas de receptores de progesterona e de estrógeno só foram observadas em $7 \%$ e $2 \%$ dos tumores respectivamente, o que é esperado de acordo com as baixas frequências descritas de ambos os receptores hormonais no CCCO. Mutações no gene TP53 usualmente levam a ausência ou a altos níveis anormais da proteína TP53, permitindo o estudo inicial da mutação pela IHQ (KÖBEL et al., 2016a) embora pouco frequente em CCCO. A expressão aberrante da proteína TP53 foi observada em uma proporção relativamente alta de pacientes na coorte combinada $(36 \%)$. A coorte brasileira apresentou uma expressão aberrante significativamente mais alta de TP53 (62\%) $\left(P=0.0033\right.$; teste de $\left.\chi^{2}\right)$. De acordo com a análise combinada com os demais marcadores moleculares testados, os resultados obtidos foram em acordo com o diagnóstico histológico de CCCO, embora pudesse haver uma aparente discordância em três casos. Nestes três casos de estádio III houve ausência de expressão de HNF1B e expressão positiva de WT1, porém fraca. Além disso, um dos casos também apresentou expressão fraca de RE e aberrância de TP53, os demais casos apresentaram expressão positiva fraca de RE ou aberrância de TP53.

A mutação do gene PIK3CA é uma alteração comum em CCCO descrita em cerca de 28.6\% a 51\% dos casos (CAUMANNS et al., 2018; FRIEDLANDER et al., 2016; ITAMOCHI et al., 2017; KIM et al., 2018; MURAKAMI et al., 2017; RAHMAN et al., 2012a; SHIBUYA et al., 2018; TAKENAKA et al., 2019; WANG et al., 2017; YANG et al., 2020). Analisamos a frequência da mutação no gene $P I K 3 C A$ pela técnica de transcrição reversa em cadeia de polimerase em tempo real (RT-PCR) e a encontramos em $29 \%$ dos casos. As mutações predominantes ocorreram no resíduo H1047, seguidos pela mutação em p.E543K. Curiosamente, $61.5 \%$ dos casos com mutação em PIK3CA apresentaram perda de expressão de ARID1A de forma concomitante, enquanto a ausência de expressão de ARID1A somente foi observada em $18.5 \%$ dos tumores com PIK3CA selvagem (Tabela 5). Além disso, mutações em PI3KCA foram menos frequentes em casos diagnosticados em estádios avançados FIGO III e IV (Tabela 5). 
Tabela 5 - Associação entre status de mutação de PIK3CA em amostras de tumores primários de CCCO e suas características.

\begin{tabular}{llll}
\hline Parâmetro & PIK3CA selvagem & PIK3CA mutação valor- $P$ \\
\hline Estádio FIGO, n & & & \\
$\quad$ Inicial (I/II) & 17 & 12 & $0.0487 *$ \\
$\quad$ Avançado (III/IV) & 15 & 2 & \\
Expressão de ARID1A, n & & & $0.0114 *$ \\
$\quad$ Negativa & 5 & 8 & \\
$\quad$ Positiva & 22 & 5 & \\
\hline
\end{tabular}

Buscando possíveis novos alvos terapêuticos, verificamos por meio de análise por PCR que 10 entre 44 casos (22.7\%) apresentaram MSI, sendo 8 deles classificados com AltoMSI. Contudo, não observamos ausência de expressão das proteínas de reparo do DNA (MMR) - MSH2, MSH6, PMS2 e MLH1 - pela imuno-histoquímica.

\subsection{Análise do número de cópias em todo o genoma de CCCO}

A plataforma OncoScan foi utilizada para definir alterações genômicas em 26 amostras de tumores primários de $\mathrm{CCCO}$ de nossas coortes. A análise evidenciou que a alteração mais frequente corresponde à amplificação do cromossomo 8q, a qual inclui o myelocytomatosis oncogene (MYC), presente em mais de metade dos casos (Figura 3). Outra região amplificada de forma frequente é o cromossomo 20q13.2 que ancora o oncogene ZNF217 (Figura 3A e 3B). ZNF217 foi encontrado amplificado em cerca de $46 \%$ dos casos.

Ganhos recorrentes, cerca de 41\% dos casos, foram notórios em 3q1.2-3q13.12 e 3q26.2. Amplificação de 17q12, contendo $H N F 1 B$, foi observado em $38 \%$ dos pacientes. Frente a descrição prévia de amplificação do gene do receptor do fator de crescimento epidérmico (EGFR) em 14\% dos casos de CCCO (CAUMANNS et al., 2018), o avaliamos em nossas coortes devido a seu potencial terapêutico, porém amplificações no gene EGFR não foram observadas. Por outro lado, o gene Human Epidermal growth factor Receptor-type 2 (HER2), outro potencial alvo-terapêutico, foi encontrado amplificado em 6 de 26 casos, em acordo com descrições prévias (CAUMANNS et al., 2018; WIEGAND et al., 2010). Quanto a análise de perdas do número de cópias, a perda do braço cromossômico 13q ocorreu em 44\% dos casos de CCCO (Figura 3A) de forma mais expressiva, enquanto outras perdas frequentes também foram observadas em 19p13.3-p13.2, 18q21.2-q22.3 e 9q13-q21.13, em $42 \%, 38 \%$ e $37 \%$ dos casos respectivamente. 
O algoritmo GISTIC foi utilizado para avaliação dos dados segmentados buscando definir picos significativos de amplificações e deleções entre as amostras de CCCO (Figura 3B). Dentre os picos de amplificação observados, estavam incluídos os genes $H N F 1 B$ em 17q12; o gene MDS1 And EVI1 Complex Locus (MECOM ) em 3q26.2 e CCNE1, este em 23\% dos casos. Por outro lado, pico de deleção significativo foi observado em 1p36.11, o qual contem ARIDIA e dessa forma deverá contribuir para a perda deste supressor tumoral nos CCCOs.

Figura 3 - Alterações no número de cópias em CCCO.
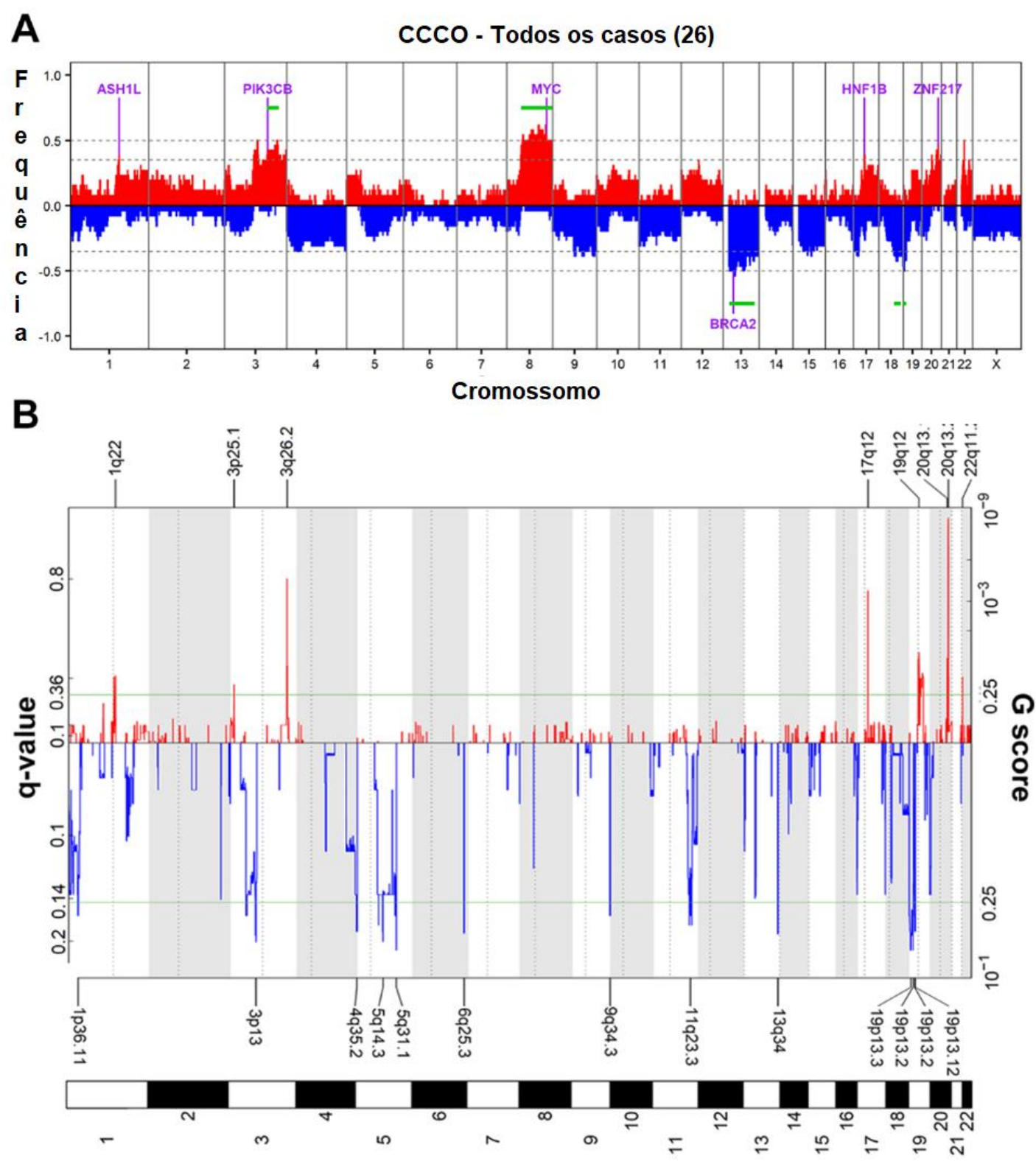

(A) Frequência de alterações do número de cópias em 26 tumores primários de $\mathrm{CCCO}$ analisados pelo OncoScan. Alterações recorrentes em genes e regiões estão indicados (linha verde). (B) Análise GISTIC de 26 tumores primários de CCCO. Alterações significativas de picos de amplificação e deleção (pontuação $G<0.25$ ) estão indicados. 


\subsection{Padrões de alterações genômicas em CCCO}

As amostras de CCCO apresentaram uma heterogeneidade notável, abrangendo desde amostras que apresentam muito poucas alterações no número de cópias até amostras com alterações em mais da metade de seu genoma. Dessa forma, inicialmente agrupamos os dados fragmentados através de uma análise hierárquica não supervisionada utilizando a razão de Log2 (LRR) (Figura 4).

Figura 4 - Perfis genômicos do CCCO.
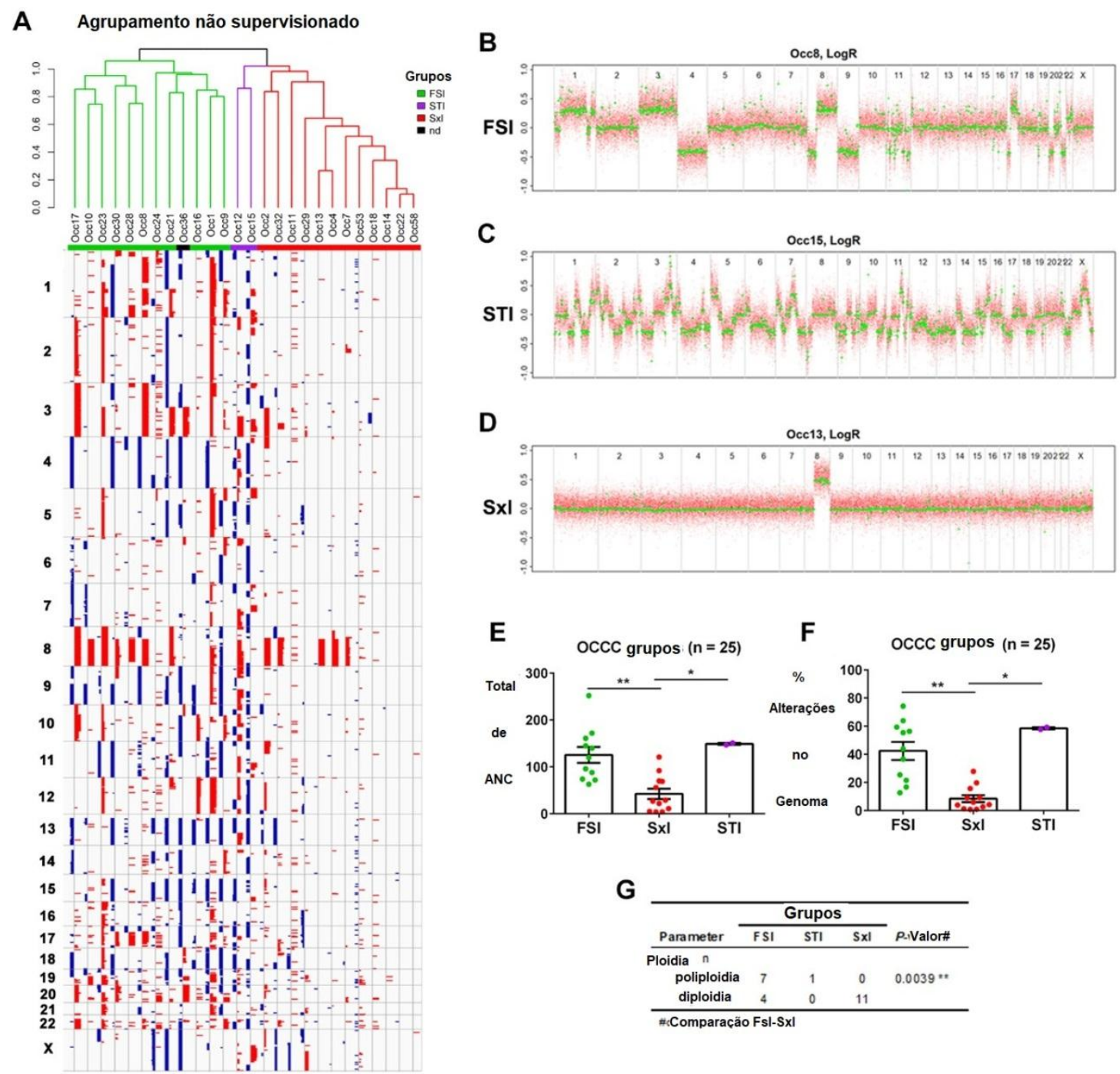

(A) Agrupamento hierárquico não supervisionado utilizando dados fragmentados de amostras de tumores primários de CCCO. Os três grupos foram nomeados Firestorm-like (FSl), Sawtooth-like (STl) e Simplex-like (Sxl). (B-D) Perfis obtidos com Razão em Log2 com ASCAT para amostras representativas : (B) FTl, (C) STl ou (D) Sxl. (E-F) Gráficos representando o (E) total de aberrações no $\mathrm{CN}(\mathbf{F})$ e a porcentagem de alterações no genoma em cada grupo. Diferenças significativas foram analisadas pelo teste de Kruskal-Wallis. (G) A ploidia foi estimada com a análise do OncoScan utilizando o algoritmo ASCAT. Amostras polipoides foram definidas como aquelas em que a ploidia $>3(n=8)$, e amostras diploides foram assim definidas cuja ploidia foi de $1.91-2.29(n=15)$. Teste exato de Fisher foi utilizado para comparar os grupos FSl e Sxl. 
As alterações genômicas encontradas em cada grupo formado foram semelhantes as descritas inicialmente em câncer de mama (HICKS et al., 2006). Tendo como fundamento esta primeira descrição, Tan et al definiu os três perfis genômicos chamados Firestorm (FS), Sawtooth (ST) e Simplex (Sx) também para CCCO (TAN et al., 2011). O perfil FS foi caracterizado por segmentos amplos de duplicação e deleção, normalmente comprometendo os cromossomos em sua totalidade ou todo seu braço, com picos ocasionais de amplificação. O perfil ST apresenta segmentos de duplicação e deleção frequentemente alternados afetando todo o cromossomo, de forma a originar um perfil genômico mais complexo. O perfil Sx foi caracterizado por picos estreitos frequentes de ganhos e deleções em um genoma essencialmente diploide. Sendo assim, em acordo com a definição descrita, nomeamos os grupos como FS-semelhante (FSl), ST-semelhante (STl) e Sx-semelhante (Sxl) (Figura 4AD). Doze amostras foram classificadas como Sxl e apresentaram um baixo número de alterações no NC e uma baixa porcentagem de alterações no genoma (Figura 4E e F). Somente duas amostras (7.7\%) foram agrupadas em STl representando uma frequência bastante inferior aos $22 \%$ descritos por Tan et al (TAN et al., 2011). Estas foram as únicas amostras a apresentarem deleções no cromossomo 10q23.2-q25.2, região que ancora o gene supressor tumoral PTEN. Umas das amostras (Occ36) poderia ser agrupada em STl ou FSl a depender dos parâmetros utilizados e devido a essa ambiguidade ela não foi agrupada. Onzes amostras foram classificadas como FSl e de forma notória 9 delas apresentaram amplificação do gene ZNF217 gene (Figura 5A-C).

Além disso, das 8 amostras polipoides contidas em nosso estudo, 7 delas eram do grupo FSl, sugerindo uma associação entre o perfil genômico e a ploidia (Figura 4G). Apesar das diferentes características entre os grupos, suas respectivas curvas de sobrevida (SG e SLP) não apresentaram diferenças (Figura 5D e E). Corroborando este achado, descrições prévias evidenciam que o agrupamento de casos de CCCO por desfecho clínico, inclui amostras com perfis genômicos distintos em um mesmo grupo prognóstico (TAN et al., 2011). 
Figura 5 - Perfis genômicos de CCCO não relacionados a desfechos de sobrevida.

A

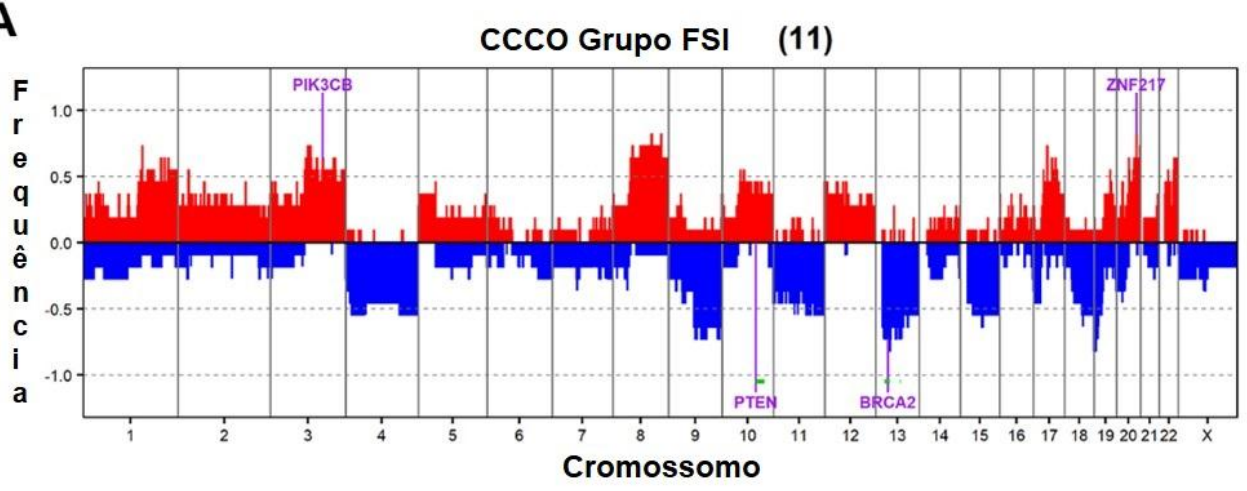

B

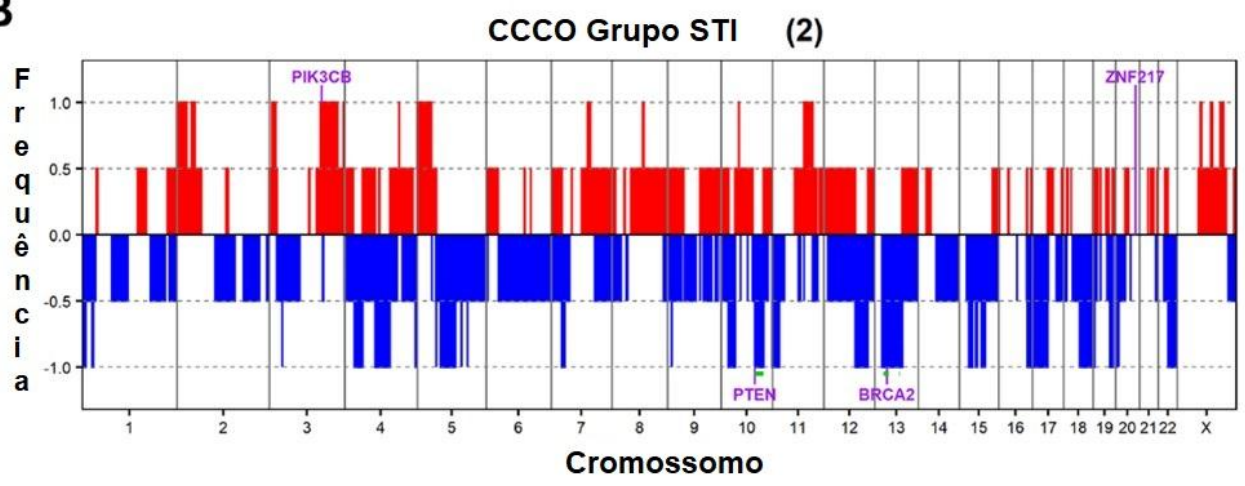

C CCCO Grupo SxI

(12)

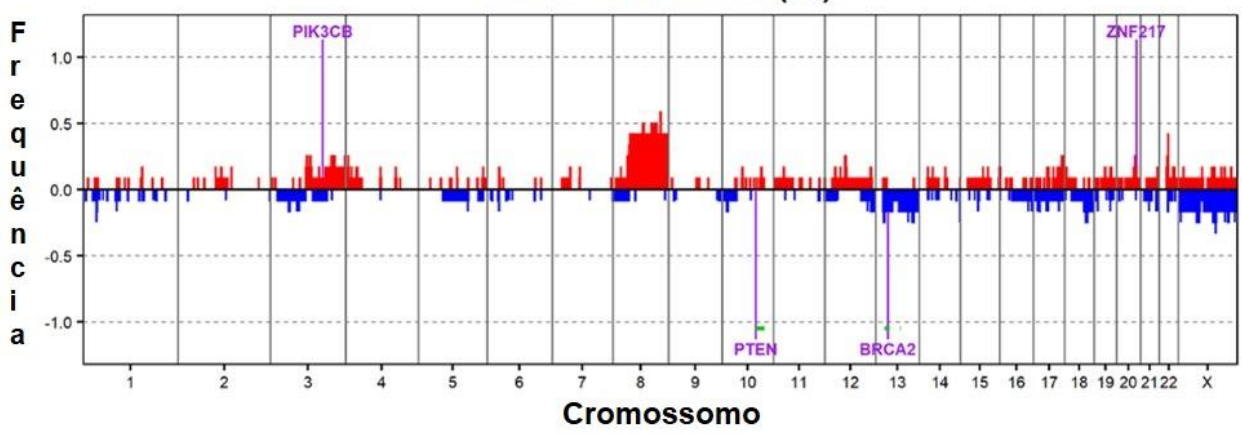

D

SG dos grupos de $\operatorname{Ccco}(n=25)$

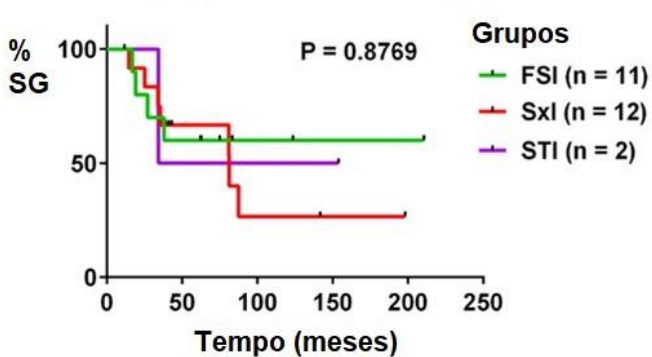

E SLP dos grupos de CCCO $(n=25)$

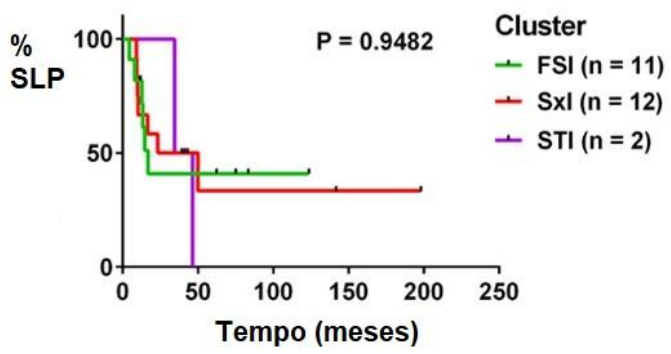

(A-C) Gráficos de frequência foram gerados para os grupos: (A) FSl, (B) STl e (C) Sxl. Alterações recorrentes em genes e regiões estão indicados (linha verde). (D) Análise de SG dos grupos de CCCO. (E) Análise de SLP dos grupos de CCCO 


\subsection{HRD está associado a perfis genômicos em CCCO}

A fim de obter informações quanto aos mecanismos que fundamentam os distintos perfis genômicos observados no CCCO, estimamos o déficit de recombinação homóloga das amostras (HRD) através da quantificação de três assinaturas genômicas - HRD utilizando o scarHRD pacote para R (Figura 6A). Transições de larga escala (HRD-LST) foram definidas como quebras cromossômicas de ao menos $10 \mathrm{Mb}$ entre regiões adjacentes, com uma distância entre elas não mais extensa que 3Mb (POPOVA et al., 2012); o desbalanço alélico do telômero (HRD-TAI) que compreende quebras que se estendem até a extremidade telomérica do cromossomo (BIRKBAK et al., 2012) e HRD associado a perda de heterozigosidade (HRD-LOH) definido por regiões de $\mathrm{LOH}$ que excedem $50 \mathrm{Mb}$ e que não incluem todo o cromossomo (ABKEVICH et al., 2012). A assinatura combinada (HRD-sum) composta pela soma das três assinaturas anteriores também foi obtida (MELINDA et al., 2016).

Conforme esperado, as assinaturas genômicas foram praticamente ausentes no grupo Sxl (Figura 6B-D). Por outro lado, o grupo FSl apresentou maiores níveis de HRD-TAI e HRD-LST e também de HRD-LOH, este em menor escala. Os achados sugerem então que HRD deve contribuir para o perfil genômico do grupo FSl. É interessante observar que as duas amostras STl apresentaram níveis bastante elevados de todas as assinaturas genômicas quando comparadas com o grupo FSl, especialmente HRD-LOH. Contudo, o baixo número de amostras de STl não nos permite observar diferenças estatisticamente significativas. A assinatura combinada, HRD-sum, associou-se perfeitamente aos grupos baseados em perfis genômicos, dessa forma sugerindo fortemente o HDR como um de seus mecanismos envolvidos (Figura 6E). Afim de verificar determinantes genômicos associados a HRD, definimos dois grupos de amostras com níveis diferentes de HRD-sum. Nove de 11 amostras (82\%) do grupo com altos níveis de HRD-sum apresentaram ganho no gene PIK3CB gene (3q22.3) e amplificação recorrente na região 3q26.2 (Figura 6F-G). 
Figura 6 - HRD em amostras de CCCO.

A

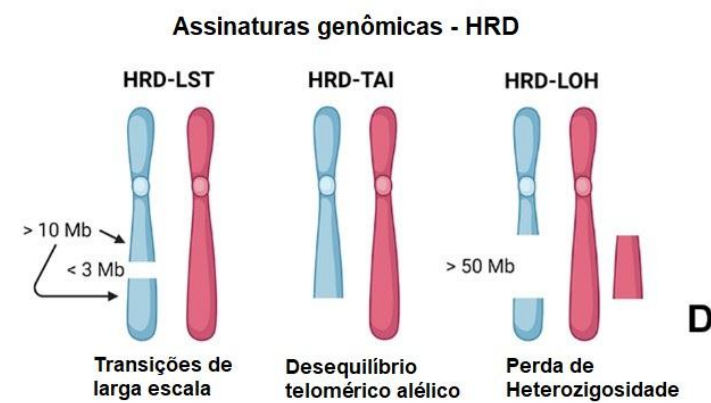

HRD-sum = HRD-LST + HRD-TAI + HRD-LOH
B

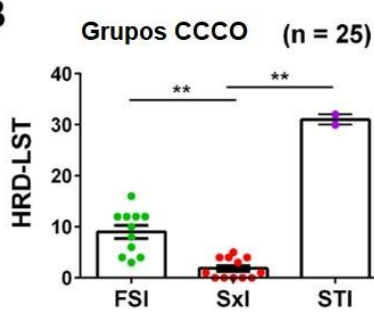

Grupos Ccco ( $n=25)$

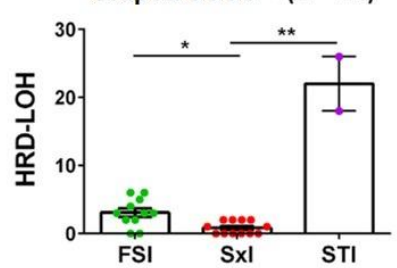

C

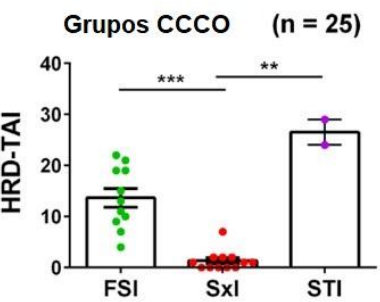

E Grupos CCco (n=25)

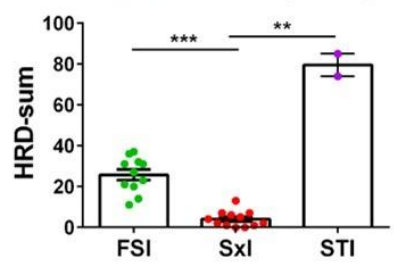

H

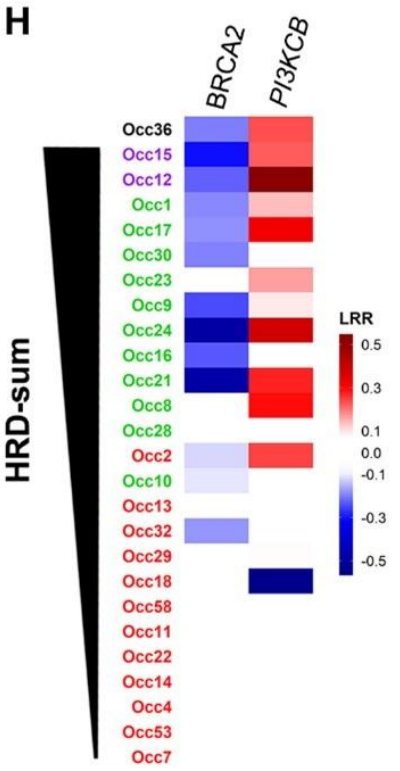

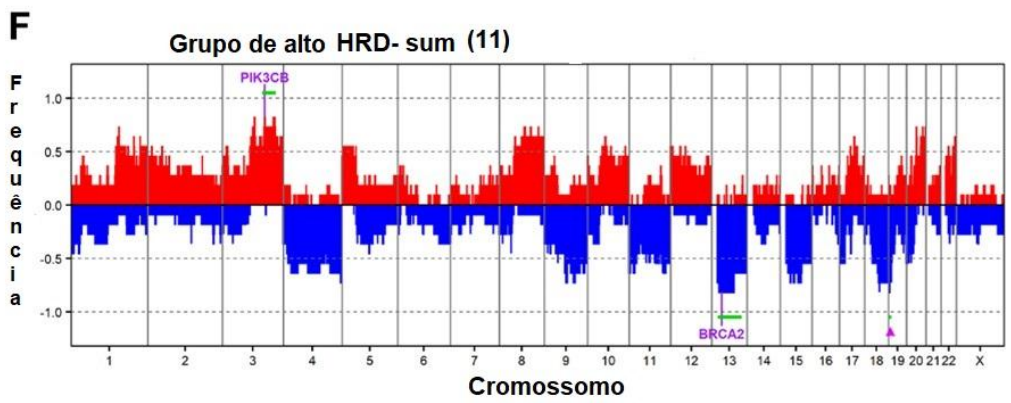

G

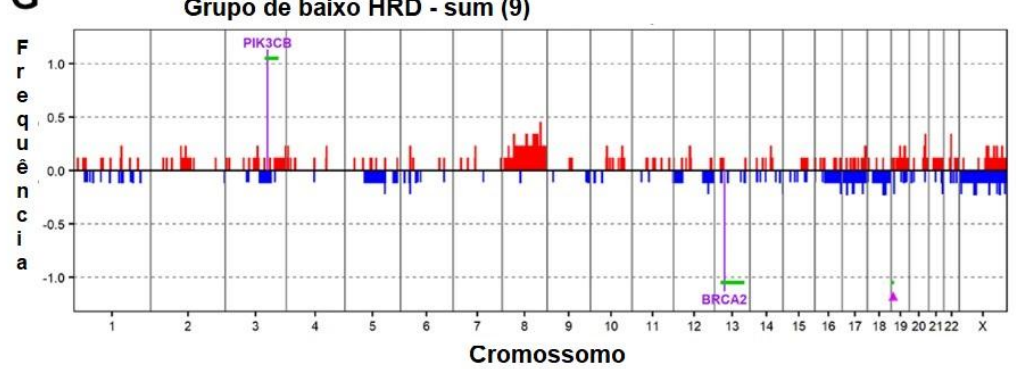


Além disso, 82\% das amostras HRD-alto apresentaram perdas em 13q12.12-q21.33, o qual inclui o gene BRCA2, e em 19p13.3. Não foram identificadas diferenças em SG e SLP entre os grupos HRD-alto e HRD-baixo (Figura 7A e B).

Figura 7 - Grupos de CCCO baseados em níveis de HRD-sum são associados a desfechos de sobrevida.

A

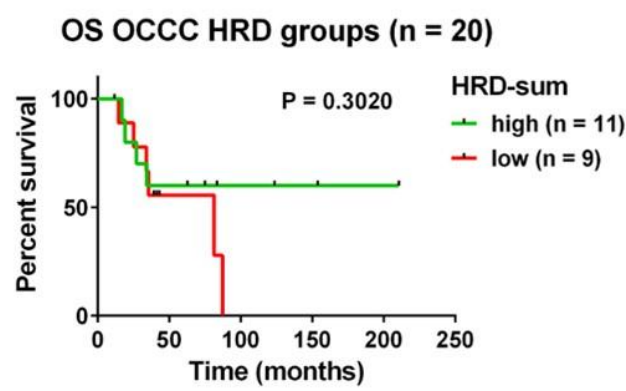

B

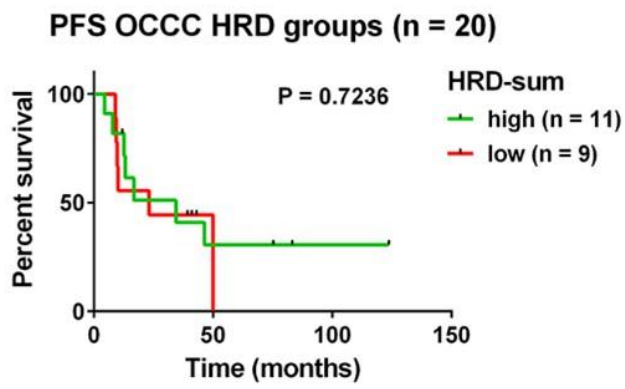

1. Análise de SG dos grupos de CCCO com diferentes níveis de HRD-sum. (B) Análise de SLP dos grupos de CCCO com diferentes níveis de HRD-sum.

De forma notável, 8 das 13 amostras com os mais altos níveis de HRD-sum de toda a coorte apresentaram perda concomitante de BRCA2 e ganho de PIK3CB $(P$-valor $=0.0016$ para Teste exato de Fisher), sugerindo que estas duas alterações devem estar associadas a HRD em CCCO (Figura 6H).

\subsection{Alterações genômicas associadas a diferentes desfechos de SG}

Nenhum dos perfis genômicos ou níveis de HRD foram associados a desfechos de SG em CCCO. Desta forma, nós realizamos comparações aleatórias entre longas e curtas SG. A frequência de ANC DNA foi comparada entre grupos compostos de amostras com SG longas e curtas e observou-se que ganho /amplificação do gene $M Y C$ foi associado a melhor SG (Figura 8A). De forma interessante, a sobrevida alcançada foi ainda mais longa no subgrupo de tumores $M Y C$-amplificado com concomitante perda na região cromossômica 13q12-q13, a qual inclui o gene $B R C A 2$, sendo assim, este subgrupo de longa sobrevida foi chamado $\mathrm{MB}$ ("MYC-BRCA2"; Figura 8B e D). Uma comparação adicional de SG foi realizada nas amostras não-MB e uma melhor sobrevida foi observada no subgrupo portador de baixo número total de alterações do $\mathrm{CN}(<30)$ (grupo FC) (Figura 8C e E). 
Figura 8 - Determinantes genômicos associados a desfechos de SG em CCCO.
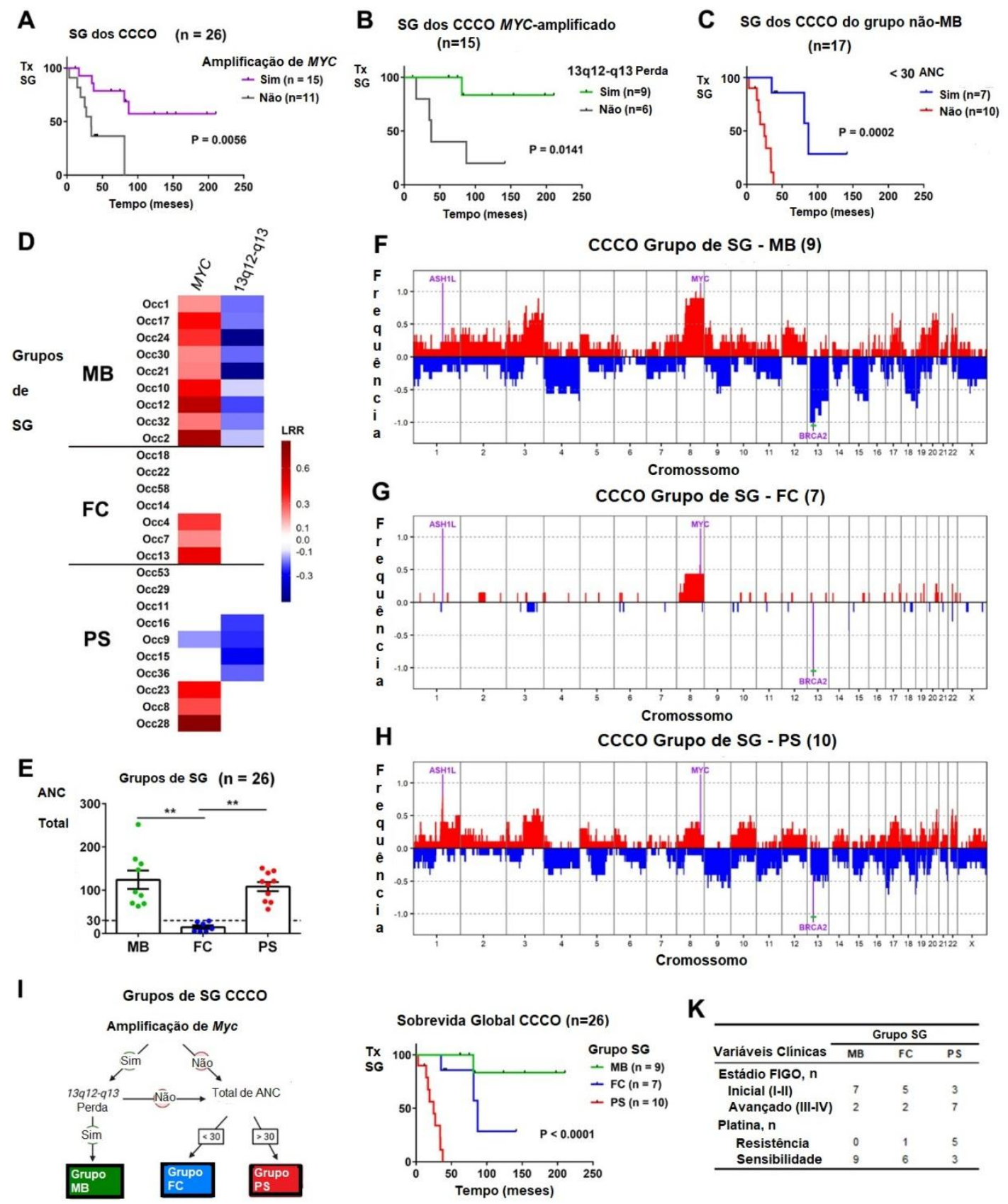

(A) Análise de sobrevida apresenta a amplificação do oncogene $M Y C$ associada a melhor sobrevida. (B) Análise de sobrevida apresenta um subgrupo de CCCO com MYC-amplificado com melhor prognóstico, definido pela perda concomitante da região cromossômica 13q12-q13, a qual inclui o gene BRCA2 gene (grupo MB). (C) Análise de sobrevida das amostras de CCCO que não compreendem a concomitância de amplificação de $M Y C$ e a perda de 13q12-q13 (não-MB CCCOs). Um subgrupo de CCCO com poucas alterações do número de cópias apresentam melhor sobrevida (grupo FC). As amostras de CCCO não pertencentes ao grupo MB nem ao grupo FC demostraram a pior sobrevida, sendo chamadas grupo PS. (D) Resumo de alterações do número de cópias em $M Y C$ e 13q12-q13. (E) Gráfico mostrando o total de alterações do número de cópias em cada grupo de SG. A linha tracejada foi estipulada em 30 alterações do CN. Diferenças significativas foram analisadas pelo teste de Kruskal-Wallis. (F-H) Gráficos de frequência foram gerados para os grupos de sobrevida: (F) MB, (G) FC e (H) PS. Genes e regiões significativamente alterados (linha verde) estão indicados. (I) Fluxograma para definição de grupos de SG. (J) Análise de sobrevida para os grupos de SG. (K) Sumário dos estádios FIGO e platino-sensibilidade das amostras em cada grupo de SG. 
O perfil genômico de todas as amostras FC foi contemplado pelo grupo Sxl, e em acordo apresentaram uma baixa frequência de alterações no genoma e LOH (Figura 9A e B). As amostras remanescentes apresentaram a pior sobrevida (grupo PS). Notavelmente, a amplificação do gene ASH1 Like Histone Lysine Methyltransferase (ASH1L) foi encontrada em 8 das 10 (80\%) amostras do grupo de sobrevida -PS, enquanto o mesmo gene estava amplificado em apenas 3 das 16 amostras (19\%) não-PS (Figura 8C e H).

A SG mediana dos casos $A S H 1 L$ - amplificados foi 34.3 meses versus 87.3 meses para os casos remanescentes $(P=0.0407$ e 0.0884 para os testes Gehan-Breslow-Wilcoxon e Logrank, respectivamente; Figura 9C).

Utilizando a avaliação descrita classificamos as amostras em três grupos de sobrevida (Figura 8I) com diferentes medianas de SG: 25 meses para PS; 87.3 meses para FC; e no grupo MB houve apenas um evento de morte (Figura 8J). Conforme esperado, todas as amostras MB foram sensíveis a platina e a maioria das amostras PS foram diagnosticadas nos estádios III ou IV (Figura 8K). Contudo, é importante evidenciar que as amostras PS diagnosticadas em estádio inicial também apresentaram uma pior sobrevida (Figura 9D) e as não-PS em estádio III apresentaram melhor prognóstico (Figura 9E).

Figura 9 - Características dos grupos de Sobrevida Global.
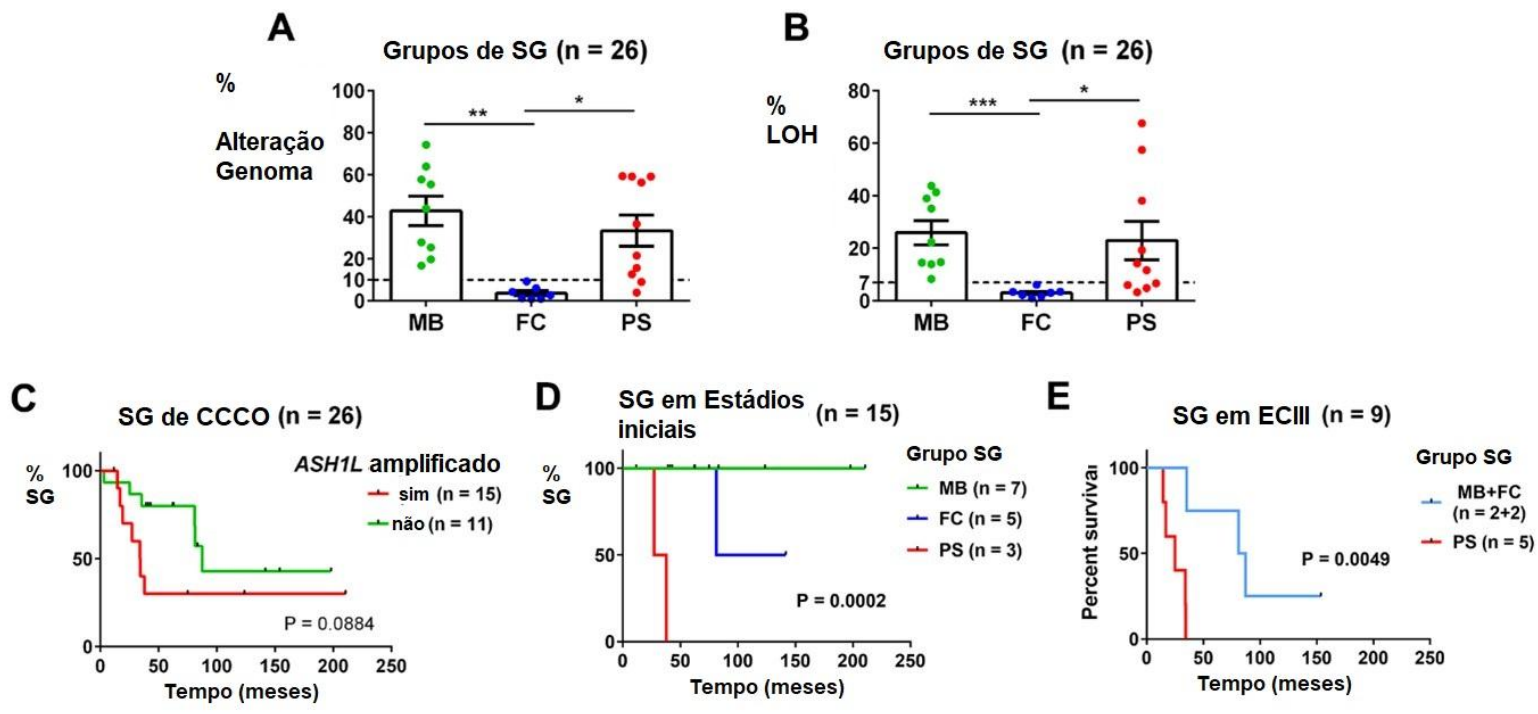

(A) Gráfico de porcentagem de alterações genômicas em cada grupo de SG. (B) Gráfico de porcentagem de LOH em cada grupo de SG. Diferenças significativas foram analisadas pelo teste de Kruskal-Wallis. (C) Análise de sobrevida baseado na presença ou não de amplificação do gene ASHIL. (D) Análise de sobrevida de CCCO em baseados nos grupos de SG. (E) Análise de sobrevida em estádios III de CCCO baseados nos grupos de SG. Como poucas amostras de estádio III não eram do grupo OS, elas foram combinadas no grupo não-PS (MB+FC). 


\subsection{Alterações genômicas associadas a progressão precoce em estádios iniciais de CCCO}

Assim como para análise de SG, nem os perfis genômicos nem os níveis de HRD foram associados a SLP. Desta maneira, realizamos uma comparação entre quatro amostras de estádios iniciais de CCCO que apresentaram recorrência antes de 17 meses de seguimento e 8 amostras que não apresentaram recorrência em até 39 meses de seguimento. Observamos que havia amplificação do gene mitogen-activated protein kinase 8 (MAPK8) (10q11.22) e dos genes megakaryoblastic leukemia (translocation) 1 (MKL1) e melanin concentrating hormone receptor 1 (MCHR1) (22q13.1-q13.2) no grupo que apresentou recorrência (Figura 10A e B). A análise de sobrevida a partir do status de amplificação de $M A P K 8$ (Figura 10C) e de $M K L 1$ (Figura 10D) revelou que uma amostra com recorrência tardia aos 46.6 meses não apresentou amplificação de nenhum destes genes. De forma interessante, o caso Occ53 apresentou amplificação do gene $M A P K 8$ em sua amostra de recaída.

Figura 10 - Alterações genômicas associadas a progressão de doença em estádios iniciais de CCCO.

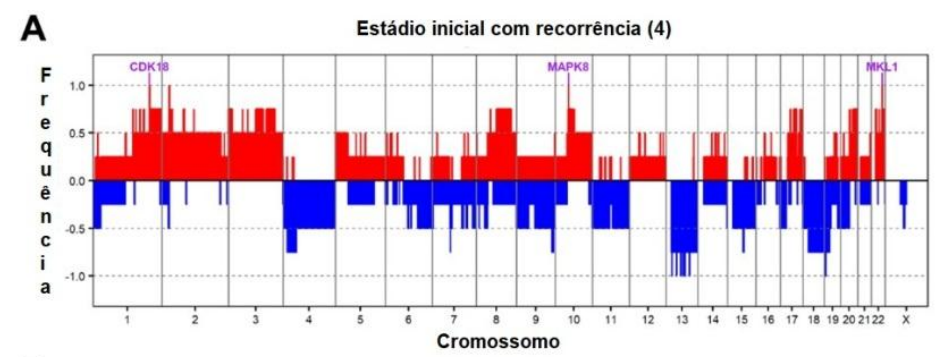

B

Estádio inicial sem recorrência (9)
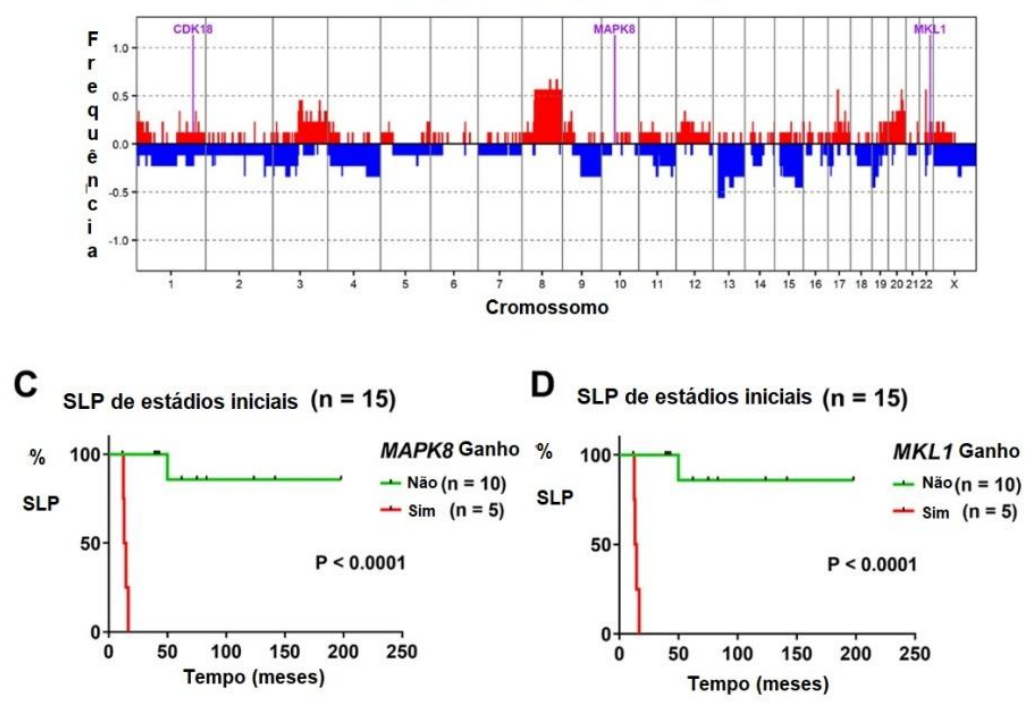

Frequência de ANC nos (A) casos que recaíram antes de 17 meses e (B) casos que não apresentaram recaída em até 39 meses. Genes amplificados de forma recorrente em casos que apresentaram recaída estão indicados. (C-D) Curvas de SLP para todos os casos iniciais da nossa coorte após classificação baseada no status de amplificação de (C) MAPK8 e (D) MKL1. 


\section{DISCUSSÃO}

CCCOs são diagnosticados de forma mais precoce que os carcinomas serosos de ovário (média 55 vs. 64 anos) nos EUA (CHAN et al., 2008), e de forma consistente, a média de idade das pacientes ao diagnóstico em nossa coorte foi de 50 anos. CCCO foi detectado ainda em idade mais precoce em mulheres com endometriose (média=38 anos, variação de 31-59 anos), o que é provavelmente ligado ao fato de que a maioria das pacientes foram diagnosticadas em estádios iniciais (BAI et al., 2016; PARK et al., 2018). Eventos tromboembólicos são mais frequentes em CCCO (42\%) que em outros carcinomas epiteliais de ovário e são associados a pior prognóstico (DUSKA et al., 2010; MATSUURA et al., 2007). Observamos uma esperada alta prevalência destes eventos (22\% das pacientes) o que foi associado a maior risco de morte independentemente do estádio. Claramente, o fator prognóstico mais importante para SG foi a resistência a quimioterapia baseada em platina, sendo fator independente com relação ao estádio, embora não tenha sido independente de TEVs. Por outro lado, o estádio avançado foi o principal fator prognóstico associado a SLP. Dentre a nossa coorte, a endometriose não foi um fator prognóstico para SG nem para SLP, fato que contrasta com a literatura prévia (OREZZOLI et al., 2008).

A análise IHQ dos marcadores moleculares pode complementar a classificação histológica, sendo suplementar para o diagnóstico patológico. O CCCO em particular, apresenta descrição de uma prevalência de acordo entre o diagnóstico histológico e a classificação imuno-histoquímica de 97\% (PERES et al., 2018). Em acordo, a grande maioria dos tumores em nossa coorte foram positivos para HNFIB e negativos para expressão de WT1, RE e RP, o que indica uma boa correlação entre o diagnóstico histológico e imuno-histoquímico (KÖBEL et al., 2016b). No entanto, a coorte brasileira apresentou uma incidência de aberrância de expressão de TP53 de 62\%, sendo mais elevada que as frequências apresentadas nas coortes de Costa Rica e Espanha, e ainda mais elevada que a descrita em outras populações (SHIH-CHU HO et al., 2001). Uma vez que mutações no gene TP53 são encontradas em quase todos os carcinomas serosos de alto grau de ovário (BELL et al., 2011), este fato poderia levantar dúvida ao diagnóstico em nossa coorte. Porém, apesar da expressão aberrante de TP53, estas amostras evidenciaram outros marcadores compatíveis com o diagnóstico de CCCO, além de histologia definidora de $\mathrm{CCCO}$ em revisão centralizada por 2 patologistas sênior. A mutação p.R337H de TP53 é particularmente disseminada no Brasil (PINTO; ZAMBETTI, 2020) e sua herança está associada a alta incidência de câncer de mama no 
país (GIACOMAZZI et al., 2014). Seria interessante verificar como esta variante pode contribuir para a alta prevalência de aberrância de TP53 na coorte brasileira de CCCO. Qualquer que seja o motivo, é importante notar que a IHQ para TP53 como avaliação para alterações no gene TP53 têm suas limitações. Um padrão imuno-histoquímico aberrante de TP53 não significa necessariamente a presença do gene TP53 alterado (YEMELYANOVA et al., 2011). De forma interessante, a análise no OncoScan detectou mutação em TP53 em 2 amostras: Occ15 com mutação em p.R248Q/L e concomitante alta expressão de TP53 na IHQ e Occ29 com mutação em p.R213* e ausência de expressão de TP53 pela IHQ.

Mutações em PIK3CA são comuns em CCCO e de forma concordante foram detectadas em $30 \%$ das nossas amostras. A proporção de casos carreando a mutação PIK3CA dentre nossa coorte foi relativamente baixa quando comparado com as já descritas em outras populações (CAUMANNS et al., 2018; FRIEDLANDER et al., 2016; ITAMOCHI et al., 2017; KIM et al., 2018; MURAKAMI et al., 2017; SHIBUYA et al., 2018; TAKENAKA et al., 2019; WANG et al., 2017; YANG et al., 2020). Uma justificativa seria o fato de que a maioria dos estudos prévios utilizou técnicas de sequenciamento para detectar mutações de $P I 3 K C A$ diferentes da que utilizamos, a qual é capaz de detectar apenas 17 mutações. Contudo, nossa coorte também observou a perda de expressão de ARID1A associada a mutação de PI3KCA, como previamente descrito (YAMAMOTO et al., 2012). Estas alterações são conhecidas por ocorrerem em estádios iniciais no desenvolvimento do $\mathrm{CCCO}$, fato corroborado por sua existência também em endometriose, uma entidade sabidamente reconhecida como lesão precursora do CCCO (ANGLESIO et al., 2015). De fato observamos que a presença de endometriose foi mais frequente na presença de mutação de PIK3CA e que ambas as situações estavam associadas ao diagnóstico de estádios iniciais.

A análise pan-genômica pelo OncoScan foi realizada em 26/60 (43\%) amostras de CCCO desta coorte. Esta plataforma não havia sido utilizada previamente para detectar alterações do número de cópias neste tipo particular de tumor de ovário; os primeiros estudos em CCCO foram realizados com Hibridização Genômica Comparativa em array (aCGH) e atualmente é utilizado o sequenciamento de todo o exoma. Sendo assim, diferentes desenhos de estudo, técnicas de análises e até diferentes pontos de corte utilizados para definir as alterações do número de cópias do DNA, podem contribuir para as diferentes frequências descritas na literatura. Apesar disso, as ANC DNA mais comuns foram facilmente identificadas nas nossas amostras, as quais incluem a amplificação do cromossomo 8q e 
20q13.2. O último contém o oncogene ZNF217 o qual não foi associado a SLP ou SG mais curtas (Log-rank $P$-valor $=03125$ e 0.5571 , respectivamente), como sugerido anteriormente (RAHMAN et al., 2012b). ZNF217 foi encontrado amplificado em uma frequência mais alta (cerca de $46 \%$ dos casos) que a descrita anteriormente em alguns estudos (20\%-36\%) (CAUMANNS et al., 2018; KUO et al., 2010; RAHMAN et al., 2012b; WIEGAND et al., 2010), porém similar a descrita por Murakami et al (MURAKAMI et al., 2017). Os ganhos recorrentes observados na região 3q26.2, cerca de $40 \%$ dos nossos casos, representam uma alteração já conhecida em CCCO, descrito previamente em 13\%, contendo vários genes associados a quinases, como o PIK3CA (CAUMANNS et al., 2018). As amostras de CCCO claramente se dividiram entre grupos baseados na arquitetura genômica de forma mais importante que nas ANC DNA de forma individual. No cenário do CCCO, estes grupos foram introduzidos por Tan et al, em 2011 (TAN et al., 2011) embasados pelos perfis genômicos descritos previamente para câncer de mama (HICKS et al., 2006). A maioria das amostras foi classificada como Sxl (46.2\%) e FSl (42.3\%). A análise do OncoScan permitiu identificar amostras polipoides e a maioria destas fazia parte do grupo FSl e nenhuma pertencia a Sxl, sugerindo que a instabilidade genômica associada ao perfil FSl pode ter como contribuinte o estado diploide (STORCHOVA; PELLMAN, 2004). De maneira interessante, as alterações de ploidia já foram associadas a desfechos clínicos em câncer de ovário, incluindo o CCCO (KRISTENSEN et al., 2003).

A respeito do grupo $\mathrm{STl}$, uma (Occ15) de suas amostras apresentou aberrância de expressão de TP53 concomitante a ausência de ganho no cromossomo 20q13.2 e perda do gene HNF1B. Ambas as amostras do grupo eram estádio III. A proporção de amostras apresentando este padrão sawtooth em nossa população foi muito inferior (7.7\%) ao descrito anteriormente (22\%) (TAN et al., 2011). Essa discrepância poderia ser reflexo das diferentes origens geográficas das pacientes.

A amplificação de $M Y C$ foi identificada em $57.7 \%$ das amostras, de forma condizente com descrições prévias (40\% a 64\%) (KIM et al., 2018; MURAKAMI et al., 2017; UEHARA et al., 2015) e foi associada a melhor sobrevida. No entanto, a perda concomitante da região do cromossomo 13 que contém BRCA2 identificou o grupo $\mathrm{MB}$, de notável bom prognóstico. A perda do gene BRCA2 foi observada em $50 \%$ da nossa coorte de forma semelhante aos $60 \%$ de perdas descritas em coorte de CCCO coreana (KIM et al., 2018). O fato de apenas a combinação das duas alterações levar a um melhor prognóstico, sugere uma interação sinérgica entre elas. A perda de $B R C A 2$ foi uma alteração recorrente nas amostras com altos níveis de HRD. Uma recente 
publicação propôs a classificação de tumores ovarianos a partir de assinaturas genômicas baseadas na presença de aberrantes mecanismos de reparo de DNA, o que resultou no estudo de diferentes subtipos histológicos em conjunto, incluindo o CCCO (WANG et al., 2017). O subgrupo de Alto-HRD, caracterizado pela potencialização das assinaturas de HRD, apresentou uma melhor sobrevida até mesmo em tumores ovarianos com ausência de mutação em $B R A C 1$ e $B R C A 2$. De forma importante, este subgrupo apresentou amplificação dos genes $M Y C$ e $M E C O M$ (3q26.2), sendo o último pertencente a região identificada como amplificada de forma recorrente no grupo de alta HRD-sum. Desta maneira, o grupo de sobrevida -MB em CCCO é reminiscente ao AltoHRD, entretanto, na análise combinada de Wang et al a maioria das amostras Alto-HRD eram do subtipo seroso de alto grau e nenhum CCCO estava presente (WANG et al., 2017). Nossa hipótese para esta observação é a de que quando diferentes subtipos histológicos são estudados juntos, os mais altos níveis de alterações encontradas no HGSC mascaram alterações similares porém, de níveis mais baixos em outros subtipos. Este fato se torna evidente se observarmos os diferentes níveis de assinaturas genômicas ente os grupos FSl e STl, em que o último apresenta níveis exagerados de assinatura HRD, em particular em HRD-LOH. Além disso, as 2 amostras STI foram as únicas da coorte que apresentaram perda de número de cópias e LOH do gene PTEN, o que poderia contribuir com defeitos de recombinação homóloga (MENDES-PEREIRA et al., 2009) e consequentemente com seu perfil-genômico complexo. Contudo, mutações em PTEN foram detectadas pelo OncoScan em 2 amostras Sxl-OCCCs, o que resultou em ausência de tinção da proteína PTEN. Este fato indica que alteração em PTEN de forma isolada não é o suficiente para alterar os níveis de HRD em CCCO.

A respeito dos grupos divididos conforme a $\mathrm{SG}$, o subgrupo de pior prognóstico (grupo PS) foi essencialmente definido pela ausência da concomitância de ganho em $M Y C /$ perda $B R C A 2$ e > 30 ANC, embora, a maioria dos CCCO deste grupo também tenha apresentado amplificação do gene ASHIL no cromossomo 1q22. Este gene codifica uma histona lisina-metiltransferase capaz de mono ou di- metilar a histona H3 lisina 36 (H3K36) (TANAKA et al., 2007) fazendo parte do grupo Tritórax de cromatinas que atuam como reguladores epigenéticos (SCHUETTENGRUBER et al., 2011). Recentemente, a função de ASHIL foi associada a leucemogênese em uma linhagem mista de leucemia (LORD; ASHWORTH, 2017) e leucemia mielóide aguda (TRISSAL et al., 2018). Sendo assim, o gene ASH1L foi recorrentemente afetado por variações estruturais e identificado como gene condutor destes tumores (FUJIMOTO et al., 2016). Além disso, de forma coerente, a 
amplificação do gene $A S H 1 L$ e a supra-regulação de mRNA foi reportada em carcinoma hepatocelular (SKAWRAN et al., 2008). O câncer anaplásico de tireoide é o mais agressivo dentre os carcinomas de tireoide e o gene ASH1L está superexpresso nestes tumores, contribuindo para sua agressividade. (XU et al., 2020). Assim como em outros tumores, o gene ASH1L pode estar associado a biologia do CCCO. Tendo em mente que reguladores epigenéticos são considerados importantes alvos para o tratamento oncológico (CHENG et al., 2019b), nossos achados abrem uma nova oportunidade de pesquisa a fim de se definir o papel do gene ASHIL em CCCO.

Um importante desafio nos CCCO é esclarecer e melhor predizer a recidiva em curto tempo nos pacientes diagnosticados em estádios iniciais. Identificamos que ganhos no gene $M A P K 8$ e em $M K L 1$ foram associados a rápida progressão de doença. O gene MAPK8 codifica a Proteína-quinase ativada pelo stress JNK1 e sua forma ativa foi associada a SLP mais curta em carcinomas de ovário (VIVAS-MEJIA et al., 2010). A importância do nosso achado reside no fato de existirem inibidores de JNK1 sendo usados em cenário de estudos clínicos em outros canceres (WU et al., 2020), o que pode eventualmente levar a utilização destes inibidores também em CCCO. De forma interessante, o ganho no gene MAPK8 foi observado após progressão na amostra Occ53 de CCCO e poucas alterações foram mantidas quando comparadas ao seu tumor primário, incluindo a amplificação dos oncogenes Wnt family member 7B (WNT7B) e mitogenactivated protein kinase 1 (MAPK1) (Figura 11). O gene $M K L 1$ codifica a proteína Leucemia Megacarioblástica 1, também conhecida como Fator de Transcrição associado a Miocardina A (MRTFA), sabidamente envolvida em diferentes funções nas células tumorais (SCHARENBERG; CHIQUET-EHRISMANN; ASPARUHOVA, 2010), em particular na promoção de metástases (FAN et al., 2021; MEDJKANE et al., 2009). Tal fato pode estar associado ao visível aumento do risco de recorrência naqueles pacientes com diagnóstico inicial de CCCO cujo tumor apresenta ganho em $M K L 1$. De fato, a superexpressão de MKL1 já foi associada previamente a pior prognóstico e promoção de metástases em carcinoma papilar de tireoide (CHENG et al., 2019a). Além disso, já foi sugerido que o gene $M K L 1$ pode ter um papel na migração e invasão de células de câncer ovariano (XU et al., 2017). 
Figura 11 - Alterações genômicas em um amostra de recorrência de CCCO.

A

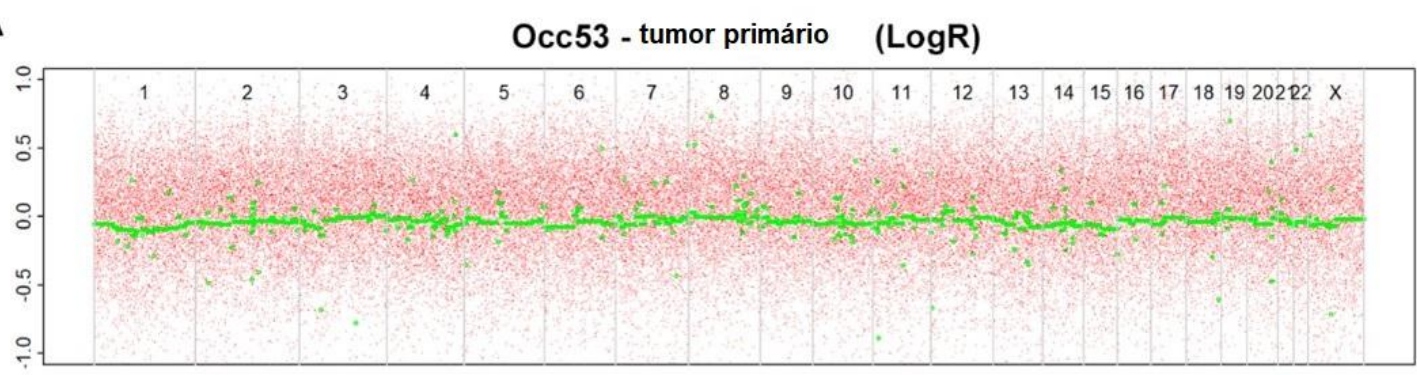

B

Occ53 - progressão (LogR)

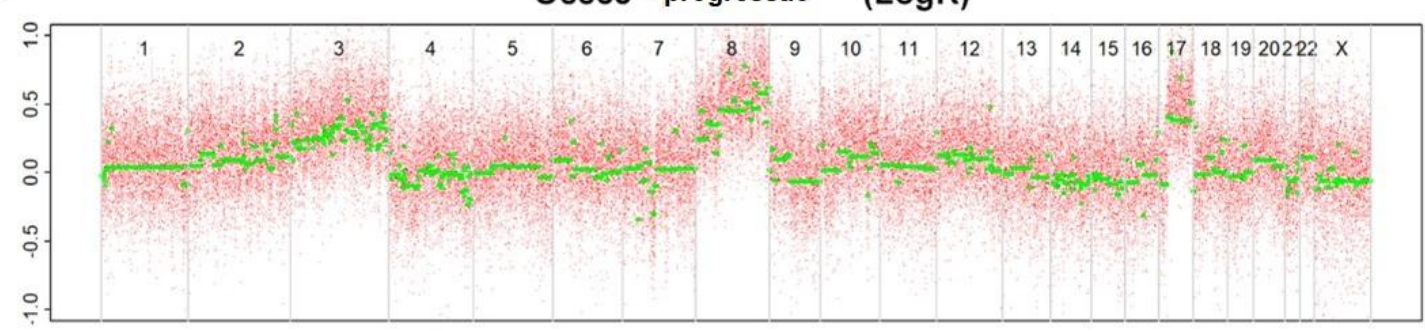

C

Occ53 - ANC em comum

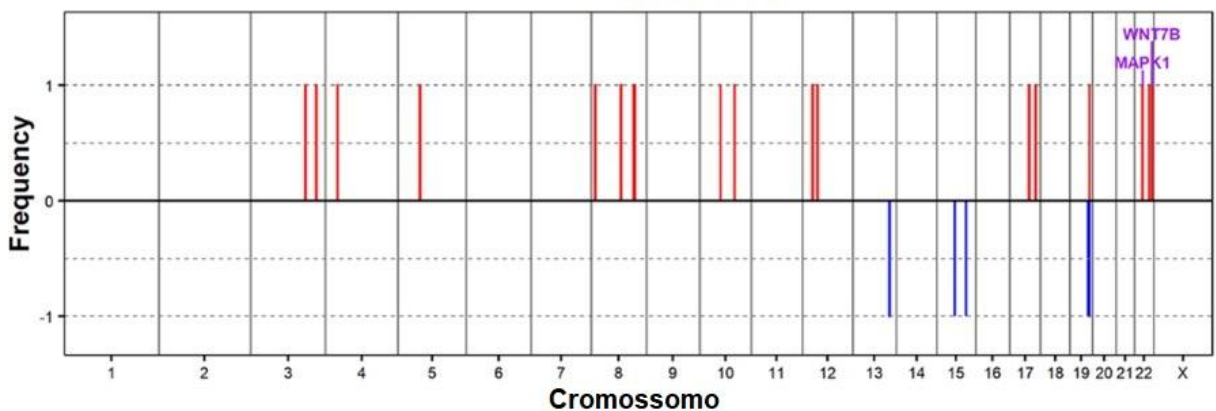

(A-B) Perfis obtidos em razão de Log2 em ASCAT para (A) uma amostra de tumor primário de $\mathrm{CCCO}$ e sua $(\mathbf{B})$ recorrência. (C) Gráfico apresentando as alterações do número de cópias e genes em comum entre as duas amostras.

A menor sensibilidade à platina dos $\mathrm{CCCO}$ quando comparada a dos outros subtipos mais comuns, carcinomas seroso e endometrióide, já é conhecida. Sendo assim, há a necessidade de se encontrar marcadores moleculares que predigam resposta assim como novos alvos terapêuticos para CCCO. Recentemente um pequeno subgrupo de CCCO com MSI que expressa PD-1/PD-L1 foi definido e sendo assim, poderia ser candidato a tratamento com inibidores de pontos de controle imunes (ICIs) (HOWITT et al., 2017; ODA et al., 2018). Howitt et al identificou 3 de 30 CCCOs (10\%) apresentando MSI (MSI-CCCO), aumento de infiltrado tumoral linfocitário e expressão de PD-1/PD-L1 (HOWITT et al., 2017; ODA et al., 2018). Os autores definiram o grupo MSI-CCCO primeiro identificando a perda de qualquer das proteínas do Reparo de DNA Mismatch (MMR) e em seguida verificando a MSI por PCR. No nosso caso, 
identificamos uma maior proporção de MSI-CCCO mesmo que não tenhamos identificado a perda de expressão de proteínas de reparo do DNA por PCR. O fato sugere que a complementação da detecção de MSI por ambos, PCR e IHQ, pode ser mais sensível para detecção de MSI-CCCO. A letalidade sintética promovida pelos inibidores da polimerase poli (ADP-ribose) (PARP) em células tumorais com HRD é uma estratégia terapêutica inovadora (LORD; ASHWORTH, 2017), em particular, nos casos de carcinoma seroso de ovário, em que cerca de 50\% dos casos apresenta HRD (BELL et al., 2011). As mutações de BRCA1 e BRCA2 são indubitavelmente associadas a HRD, todavia, diferentemente dos carcinomas serosos, os CCCO frequentemente tem uma frequência mais baixa destas mutações (KHALIQUE et al., 2020). Recentemente, foram testados 16 genes associados a recombinação homóloga em uma coorte japonesa; 28\% dos CCCOs apresentou alterações sugerindo que mais pacientes poderiam ser selecionados para o tratamento com inibidores de PARP (SUGINO et al., 2019). Nós observamos que a perda do número de cópias no gene BRCA2 e o ganho delas no gene PIK3CB estava presente nos CCCOs com altos níveis de HRD-sum, os quais incluíam a maioria dos casos dos grupos FSl e STl. Como mencionado anteriormente, os níveis de HRD-sum do grupo FSl são inferiores aos das 2 amostras do grupo STl. Desta forma, seria interessante verificar qual o nível necessário de HRD-sum para se utilizar inibidores de PARP em CCCO, assim como verificar uma possível associação com a perda do NC de BRCA2. Além disso, o ganho no número de cópias observado no gene PIK3CB nos casos de altos níveis de HRD-sum deve estar associado aos resultados promissores observados com o uso da combinação de inibidores da via PI3K e PARP (REHMAN; LORD; ASHWORTH, 2012; YAP et al., 2020). Já foi descrito que pacientes portadores de carcinoma ovariano com mutações em genes associados à HRD apresentam uma maior sensibilidade à platina e sobrevida global prolongada (PENNINGTON et al., 2014). No caso dos CCCO, observamos que a HRD-sum e a perda do número de cópias de BRCA2 não estavam associados a SG mais longa ou platino-sensibilidade. Porém, todos os casos com concomitante ganho em MYC e perda de BRCA2 apresentaram melhor prognóstico e sensibilidade à platina.

Terapias alvo para inibição de quinases alteradas em CCCO já foram propostas, incluindo a inibição de mTORC1/2 (CAUMANNS et al., 2018). Neste sentido buscamos e identificamos amplificações de genes quinase em casos iniciais com recidivas precoces, tais como nos genes cyclin dependent kinase 18 (CDK18), ETS transcription factor ELK4 (ELK4) e ALK receptor tyrosine kinase ( $A L K$ ). Amplificações em CDK18 e ELK4 foram encontrados 
em 4 de 4 casos iniciais de CCCO com recaída precoce e em um caso entre 9 que não apresentaram recaída durante o seguimento. O gene $A L K$ estava amplificado em 3 de 4 estádios iniciais com recidiva precoce versus 0 de 9 casos que não apresentaram recaída. Tais achados poderiam levantar a hipótese de potenciais novos alvos terapêuticos para esta neoplasia. 


\section{CONCLUSÃO}

Em conclusão, este estudo mostra a heterogeneidade molecular do carcinoma de células claras de ovário, um subtipo de carcinoma ovariano menos representado nos estudos, em uma população geográfica dificilmente estudada neste cenário. Apesar de todas as suas disparidades geográficas e moleculares, globalmente o CCCO representa um subtipo de carcinoma epitelial de ovário de mais alta letalidade, ainda tratado conforme suas contrapartes. Os variáveis perfis genômicos descritos enfatizam a necessidade da busca de alvos terapêuticos individualizados para tratamentos mais exitosos e a possibilidade de buscalos. Neste sentido, geramos hipóteses de novos alvos terapêuticos e de marcadores prognósticos. Devido a sua baixa incidência, o CCCO exige a colaboração de grupos de pesquisa para o desenvolvimento de novos estudos. 


\section{REFERÊNCIAS}

ABKEVICH, V. et al. Patterns of genomic loss of heterozygosity predict homologous recombination repair defects in epithelial ovarian cancer. British Journal of Cancer, v. 107, n. 10, p. 1776-1782, 2012.

ANGLESIO, M. . et al. Clear cell carcinoma of the ovary: a report from the first Ovarian Clear Cell Symposium, June 24th, 2010. Gynecologic oncology, v. 121, n. 2, p. 407-415, 1 maio 2011.

ANGLESIO, M. S. et al. Multifocal endometriotic lesions associated with cancer are clonal and carry a high mutation burden. Journal of Pathology, v. 236, n. 2, p. 201-209, 2015.

BAI, H. et al. Prognostic value of endometriosis in patients with stage I ovarian clear cell carcinoma: Experiences at three academic institutions. Gynecologic Oncology, v. 143, n. 3, p. 526-531, 2016.

BELL, D. et al. Integrated genomic analyses of ovarian carcinoma. Nature, v. 474, n. 7353, p. 609-615, 2011.

BIRKBAK, N. J. et al. Telomeric allelic imbalance indicates defective DNA repair and sensitivity to DNA-damaging agents. Cancer Discovery, v. 2, n. 4, p. 366-375, 2012.

CAUMANNS, J. J. et al. Integrative kinome profiling identifies mTORC1/2 inhibition as treatment strategy in ovarian clear cell Carcinoma. Clinical Cancer Research, v. 24, n. 16, p. 3928-3940, 2018.

CHAN, J. K. et al. Do clear cell ovarian carcinomas have poorer prognosis compared to other epithelial cell types? A study of 1411 clear cell ovarian cancers. Gynecologic Oncology, v. 109, n. 3, p. 370-376, 2008.

CHANDLER, R. et al. Coexistent ARID1A-PIK3CA mutations promote ovarian clear-cell tumorigenesis through pro-tumorigenic inflammatory cytokine signalling. Nature communications, v. 6, 2015.

CHEAIB, B. The PI3K/Akt/mTOR pathway in ovarian cancer: therapeutic opportunities and challenges. Chin J Cancer, v. 34, p. 4-16, 2015.

CHENG, X. et al. MKL1 overexpression predicts poor prognosis in patients with papillary thyroid cancer and promotes nodal metastasis. Journal of Cell Science, v. 132, n. 16, 2019a. 
CHENG, Y. et al. Targeting epigenetic regulators for cancer therapy: Mechanisms and advances in clinical trials. Signal Transduction and Targeted Therapy, v. 4, n. 1, 2019b.

CHIANG, Y. et al. Trends in incidence and survival outcome of epithelial ovarian cancer: 30year national population-based registry in Taiwan. Journal of Gynecologic Oncology, v. 24, n. 4, p. 342-351, 2 out. 2013.

COBURN, S. et al. International patterns and trends in ovarian cancer incidence, overall and by histologic subtype. International journal of cancer, v. 140, n. 11, p. 2451-2460, 1 jun. 2017.

DUSKA, L. R. et al. When "never-events" occur despite adherence to clinical guidelines: The case of venous thromboembolism in clear cell cancer of the ovary compared with other epithelial histologic subtypes. Gynecologic Oncology, v. 116, n. 3, p. 374-377, 2010.

FAN, H. et al. MKL1-induced lncRNA SNHG18 drives the growth and metastasis of nonsmall cell lung cancer via the miR-211-5p/BRD4 axis. Cell Death and Disease, v. 12, n. 1, 2021.

FRIEDLANDER, M. L. et al. Molecular profiling of clear cell ovarian cancers: Identifying potential treatment targets for clinical trials. International Journal of Gynecological Cancer, v. 26, n. 4, p. 648-654, 2016.

FUJIMOTO, A. et al. Whole-genome mutational landscape and characterization of noncoding and structural mutations in liver cancer. Nature Genetics, v. 48, n. 5, p. 500-509, 2016.

GIACOMAZZI, J. et al. Prevalence of the TP53 p.R337H mutation in breast cancer patients in Brazil. PloS one, v. 9, n. 6, p. e99893, jan. 2014.

HICKS, J. et al. Novel patterns of genome rearrangement and their association with survival in breast cancer. Genome Research, v. 16, n. 12, p. 1465-1479, out. 2006.

HOGEN, L. et al. Patterns of recurrence and impact on survival in patients with clear cell ovarian carcinoma. International journal of gynecological cancer : official journal of the International Gynecological Cancer Society, v. 29, n. 7, p. 1164-1169, 1 set. 2019.

HOWITT, B. E. et al. Clear cell ovarian cancers with microsatellite instability: A unique subset of ovarian cancers with increased tumor-infiltrating lymphocytes and PD-1/PD-L1 expression. OncoImmunology, v. 6, n. 2, p. 1-4, 2017.

IIDA, Y. et al. Clear cell carcinoma of the ovary: a clinical and molecular perspective. International journal of gynecological cancer: official journal of the International Gynecological Cancer Society, v. 31, n. 4, p. 605-616, 1 abr. 2021. 
ITAMOCHI, H. et al. Whole-genome sequencing revealed novel prognostic biomarkers and promising targets for therapy of ovarian clear cell carcinoma. British Journal of Cancer, v. 117, n. 5, p. 717-724, 2017.

IWASAKI, M. et al. Secular trends in cancer mortality among Japanese immigrants in the state of São Paulo, Brazil, 1979-2001. European Journal of Cancer Prevention, v. 17, n. 1, p. 1-8, 2008.

KATO, N.; SASOU, S. I.; MOTOYAMA, T. Expression of hepatocyte nuclear factor-1beta (HNF-1beta) in clear cell tumors and endometriosis of the ovary. Modern Pathology, v. 19, n. 1, p. 83-89, 2006.

KHALIQUE, S. et al. Translational genomics of ovarian clear cell carcinoma. Seminars in Cancer Biology, v. 61, p. 121-131, 1 abr. 2020.

KIM, I. et al. Genomic landscape of ovarian clear cell carcinoma via whole exome sequencing. Gynecologic Oncology, v. 148, n. 2, p. 375-382, 2018.

KIM, S. et al. Incidence of epithelial ovarian cancer according to histologic subtypes in Korea, 1999 to 2012. Journal of Gynecologic Oncology, v. 27, n. 1, p. e5-e5, 1 dez. 2015.

KÖBEL, M. et al. Differences in tumor type in low-stage versus high-stage ovarian carcinomas. International Journal of Gynecological Pathology : Official Journal of the International Society of Gynecological Pathologists, v. 29, n. 3, p. 203-211, 1 maio 2010.

KÖBEL, M. et al. Optimized p53 immunohistochemistry is an accurate predictor of TP53 mutation in ovarian carcinoma. Journal of Pathology: Clinical Research, v. 2, n. 4, p. 247-258, 2016a.

KÖBEL, M. et al. An Immunohistochemical Algorithm for Ovarian Carcinoma Typing. International Journal of Gynecological Pathology, v. 35, n. 5, p. 430-441, 2016b.

KORENAGA, T. R. et al. The elevated risk of ovarian clear cell carcinoma among Asian Pacific Islander women in the United States is not affected by birthplace. Gynecologic Oncology, v. 157, n. 1, p. 62-66, 1 abr. 2020.

KRISTENSEN, G. B. et al. Large-scale genomic instability predicts long-term outcome for women with invasive stage I ovarian cancer. Annals of Oncology, v. 14, n. 10, p. 1494-1500, 2003.

KUO, K. T. et al. DNA copy numbers profiles in affinity-purified ovarian clear cell carcinoma. Clinical Cancer Research, v. 16, n. 7, p. 1997-2008, 2010. 
LEE, Y. Y. et al. Prognosis of ovarian clear cell carcinoma compared to other histological subtypes: A meta-analysis. Gynecologic Oncology, v. 122, n. 3, p. 541-547, 1 set. 2011.

LORD, C. J.; ASHWORTH, A. PARP inhibitors: Synthetic lethality in the clinic. Science, v. 355, n. 6330, p. 1152-1158, mar. 2017.

MARKS, E. I., BROWN, V. S. AND DIZON, D. S. Genomic and Molecular Abnormalities in Gynecologic Clear Cell Carcinoma. Am. J. Clin. Oncol. Cancer Clin. Trials, v. 18, p. 139$145,2020$.

MATSUURA, Y. et al. Thromboembolic complications in patients with clear cell carcinoma of the ovary. Gynecologic Oncology, v. 104, n. 2, p. 406-410, 2007.

MEDJKANE, S. et al. Myocardin-related transcription factors and SRF are required for cytoskeletal dynamics and experimental metastasis. Nature Cell Biology, v. 11, n. 3, p. 257268, 2009.

MELINDA, L. T. et al. Homologous recombination deficiency (hrd) score predicts response to platinum-containing neoadjuvant chemotherapy in patients with triple-negative breast cancer. Clinical Cancer Research, v. 22, n. 15, p. 3764-3773, 2016.

MENDES-PEREIRA, A. M. et al. Synthetic lethal targeting of PTEN mutant cells with PARP inhibitors. EMBO Molecular Medicine, v. 1, n. 6-7, p. 315-322, 2009.

MERMEL, C. et al. GISTIC2.0 facilitates sensitive and confident localization of the targets of focal somatic copy-number alteration in human cancers. Genome biology, v. 12, n. 4, 28 abr. 2011.

MURAKAMI, R. et al. Exome Sequencing Landscape Analysis in Ovarian Clear Cell Carcinoma Shed Light on Key Chromosomal Regions and Mutation Gene Networks. American Journal of Pathology, v. 187, n. 10, p. 2246-2258, 2017.

MUTCH, D. G.; PRAT, J. 2014 FIGO staging for ovarian, fallopian tube and peritoneal cancer. Gynecologic Oncology, v. 133, n. 3, p. 401-404, 2014.

ODA, K. et al. Genomics to immunotherapy of ovarian clear cell carcinoma: Unique opportunities for management. Gynecologic Oncology, v. 151, n. 2, p. 381-389, 2018.

OKAMOTO, A. et al. Gynecologic Cancer InterGroup (GCIG) consensus review for clear cell carcinoma of the ovary. International journal of gynecological cancer: official journal of the International Gynecological Cancer Society, v. 24, n. 9 Suppl 3, p. S20S25, 1 nov. 2014. 
OKAMOTO, A. et al. Somatic Copy Number Alterations Associated with Japanese or Endometriosis in Ovarian Clear Cell Adenocarcinoma. PLOS ONE, v. 10, n. 2, p. e0116977, 6 fev. 2015.

OREZZOLI, J. P. et al. Prognostic implication of endometriosis in clear cell carcinoma of the ovary. Gynecologic Oncology, v. 110, n. 3, p. 336-344, 2008.

PARK, J. Y. et al. Significance of ovarian endometriosis on the prognosis of ovarian clear cell carcinoma. International Journal of Gynecological Cancer, v. 28, n. 1, p. 11-18, 2018.

PEARCE, C. L. et al. Association between endometriosis and risk of histological subtypes of ovarian cancer: a pooled analysis of case-control studies. The Lancet Oncology, v. 13, n. 4, p. 385-394, 1 abr. 2012.

PECTASIDES, D. et al. Advanced stage clear-cell epithelial ovarian cancer: the Hellenic Cooperative Oncology Group experience. Gynecologic oncology, v. 102, n. 2, p. 285-291, ago. 2006.

PENNINGTON, K. P. et al. Germline and somatic mutations in homologous recombination genes predict platinum response and survival in ovarian, fallopian tube, and peritoneal carcinomas. Clinical Cancer Research, v. 20, n. 3, p. 764-775, 2014.

PERES, L. C. et al. Histotype classification of ovarian carcinoma: A comparison of approaches. Gynecologic Oncology, v. 151, n. 1, p. 53-60, 2018.

PINTO, E. M.; ZAMBETTI, G. P. What 20 years of research has taught us about the TP53 p.R337H mutation. Cancer, v. 126, n. 21, p. 4678-4686, 2020.

POPOVA, T. et al. Ploidy and large-scale genomic instability consistently identify basal-like breast carcinomas with BRCA1/2 inactivation. Cancer Research, v. 72, n. 21, p. 5454-5462, 2012.

RAHMAN, M. et al. Clinicopathologic and biological analysis of PIK3CA mutation in ovarian clear cell carcinoma. Human Pathology, v. 43, n. 12, p. 2197-2206, 2012a.

RAHMAN, M. T. et al. Prognostic and therapeutic impact of the chromosome 20q13.2 ZNF217 locus amplification in ovarian clear cell carcinoma. Cancer, v. 118, n. 11, p. 2846$2857,2012 b$.

REHMAN, F. L.; LORD, C. J.; ASHWORTH, A. The promise of combining inhibition of PI3K and PARP as cancer therapy. Cancer Discovery, v. 2, n. 11, p. 982-984, 2012. 
REICH, M. et al. GenePattern 2.0. Nature Genetics 2006 38:5, v. 38, n. 5, p. 500-501, maio 2006.

SCHARENBERG, M. A.; CHIQUET-EHRISMANN, R.; ASPARUHOVA, M. B. Megakaryoblastic leukemia protein-1 (MKL1): Increasing evidence for an involvement in cancer progression and metastasis. International Journal of Biochemistry and Cell Biology, v. 42, n. 12, p. 1911-1914, 2010.

SCHUETTENGRUBER, B. et al. Trithorax group proteins: Switching genes on and keeping them active. Nature Reviews Molecular Cell Biology, v. 12, n. 12, p. 799-814, 2011.

SHIBUYA, Y. et al. Identification of somatic genetic alterations in ovarian clear cell carcinoma with next generation sequencing. Genes Chromosomes and Cancer, v. 57, n. 2, p. 51-60, 2018.

SHIH-CHU HO, E. et al. P53 Mutation Is Infrequent in Clear Cell Carcinoma of the Ovary. Gynecologic Oncology, v. 80, n. 2, p. 189-193, 2001.

SKAWRAN, B. et al. Gene expression profiling in hepatocellular carcinoma: Upregulation of genes in amplified chromosome regions. Modern Pathology, v. 21, n. 5, p. 505-516, 2008.

STORCHOVA, Z.; PELLMAN, D. From polyploidy to aneuploidy, genome instability and cancer. Nature Reviews Molecular Cell Biology, v. 5, n. 1, p. 45-54, 2004.

STUART, G. C. E. et al. 2010 Gynecologic Cancer InterGroup (GCIG) consensus statement on clinical trials in ovarian cancer: Report from the fourth ovarian cancer consensus conference. International Journal of Gynecological Cancer, v. 21, n. 4, p. 750-755, 2011.

SUGINO, K. et al. Germline and somatic mutations of homologous recombination-associated genes in Japanese ovarian cancer patients. Scientific Reports, v. 9, n. 1, p. 1-9, 2019.

SUGIYAMA, T. Clinical characteristics of clear cell carcinoma of the ovary: a distinct histologic type with poor prognosis and resistance to platinum-based chemotherapy. Cancer, v. 88 , p. 2584-9, 2000.

SUNG, H. et al. Global Cancer Statistics 2020: GLOBOCAN Estimates of Incidence and Mortality Worldwide for 36 Cancers in 185 Countries. CA: a cancer journal for clinicians, v. 71, n. 3, p. 209-249, maio 2021.

SUNG, P. et al. Global distribution pattern of histological subtypes of epithelial ovarian cancer: a database analysis and systematic review. Gynecologic oncology, v. 133, n. 2, p. 147-154, 2014. 
TAKENAKA, M. et al. Survival following chemotherapy in ovarian clear cell carcinoma is not associated with pathological misclassification of tumor histotype. Clinical Cancer Research, v. 25, n. 13, p. 3962-3973, 2019.

TAN, D. S. P. et al. Genomic Analysis Reveals the Molecular Heterogeneity of Ovarian Clear Cell Carcinomas. Clinical Cancer Research, v. 17, n. 6, p. 1521-1534, 15 mar. 2011.

TANAKA, Y. et al. Trithorax-group protein ASH1 methylates histone H3 lysine 36. Gene, v. 397, n. 1-2, p. 161-168, 2007.

TRISSAL, M. C. et al. MIR142 loss-of-function mutations derepress ASH1L to increase HOXA gene expression and promote leukemogenesis. Cancer Research, v. 78, n. 13, p. 3510-3521, 2018.

UEHARA, Y. et al. Integrated copy number and expression analysis identifies profiles of whole-arm chromosomal alterations and subgroups with favorable outcome in ovarian clear cell carcinomas. PLoS ONE, v. 10, n. 6, p. 1-18, 2015.

VIVAS-MEJIA, P. et al. c-Jun-NH2-kinase-1 inhibition leads to antitumor activity in ovarian cancer. Clinical Cancer Research, v. 16, n. 1, p. 184-194, 2010.

WANG, Y. K. et al. Genomic consequences of aberrant DNA repair mechanisms stratify ovarian cancer histotypes. Nature Genetics, v. 49, n. 6, p. 856-864, 2017.

WIEGAND, K. C. et al. ARID1A Mutations in Endometriosis-Associated Ovarian Carcinomas. New England Journal of Medicine, v. 363, n. 16, p. 1532-1543, out. 2010.

WU, Q. et al. Selective inhibitors for JNK signalling: a potential targeted therapy in cancer. Journal of Enzyme Inhibition and Medicinal Chemistry, v. 35, n. 1, p. 574-583, 2020.

XU, B. et al. Novel role of ASH1L histone methyltransferase in anaplastic thyroid carcinoma. Journal of Biological Chemistry, v. 295, n. 26, p. 8834-8845, 2020.

$\mathrm{XU}, \mathrm{W}$. et al. MKL1 links epigenetic activation of MMP2 to ovarian cancer cell migration and invasion. Biochemical and Biophysical Research Communications, v. 487, n. 3, p. 500-508, 2017.

YAHATA, T.; BANZAI, C.; TANAKA, K. Histology-specific long-term trends in the incidence of ovarian cancer and borderline tumor in Japanese females: A population-based study from 1983 to 2007 in Niigata. Journal of Obstetrics and Gynaecology Research, v. 38, n. 4, p. 645-650, 1 abr. 2012. 
YAMAMOTO, S. et al. Loss of ARID1A protein expression occurs as an early event in ovarian clear-cell carcinoma development and frequently coexists with PIK3CA mutations. Modern Pathology, v. 25, n. 4, p. 615-624, 2012.

YANG, Q. et al. Genomic characterization of Chinese ovarian clear cell carcinoma identifies driver genes by whole exome sequencing. Neoplasia (United States), v. 22, n. 9, p. 399-430, 2020 .

YAP, T. A. et al. Phase i trial of the parp inhibitor olaparib and akt inhibitor capivasertib in patients with brca1/2-and non-brca1/2-mutant cancers. Cancer Discovery, v. 10, n. 10, p. 1528-1543, 2020.

YEMELYANOVA, A. et al. Immunohistochemical staining patterns of p53 can serve as a surrogate marker for TP53 mutations in ovarian carcinoma: An immunohistochemical and nucleotide sequencing analysis. Modern Pathology, v. 24, n. 9, p. 1248-1253, 2011. 


\section{ANEXOS \\ TERMO DE CONSENTIMENTO LIVRE E ESCLARECIDO \\ Projeto: Projeto de estudo: Perfil Molecular do Carcinoma de células Claras de Ovário e sua correlação clínica na experiência de três instituições.}

Pesquisador responsável: Prof. Dr. Eduardo Magalhães Rego

Pós Graduanda: Mariana de Paiva Batista

Contato: Avenida Bandeirante, nº 3900; Campus Universitário; Bairro Monte Alegre; HCFMRP-USP; Divisão de Oncologia Clínica; Ribeirão Preto - SP; Tel.: (16) 3602-2304

O Sr. (a) está sendo convidado para participar como voluntário da pesquisa. Após ser esclarecido (a) sobre as informações a seguir, no caso de aceitar fazer parte do estudo, assine ao final deste documento que está em duas vias. Uma delas é sua e a outra é do pesquisador responsável.

Se o Sr. (a) tiver dúvidas ou se sentir de alguma forma prejudicado (a) sobre os aspectos éticos dessa pesquisa, poderá entrar em contato com o Comitê de Ética em Pesquisa do Hospital das Clinicas de Ribeirão Preto da USP, pelo telefone (16) 3602-2228, que funciona de segunda à sexta-feira das 8:00 às 17:00 h. O Comitê de Ética em Pesquisa é formado por um grupo de pessoas que avalia projetos para ver se apresenta algum prejuízo para quem participa da pesquisa.

A Sra. está sendo acompanhado no Serviço de Oncologia Clínica e Ginecologia deste hospital para tratamento e seguimento de uma neoplasia (tumor) localizada nos ovários. Quando a Sra. fez a biópsia ou cirurgia da lesão nos ovários para confirmar o diagnóstico de tumor, uma pequena parte deste material foi armazenada no Serviço de Anatomia Patológica.

Neste momento, gostaríamos de convidar a Sra. a participar deste estudo onde não modificaremos em nada seu tratamento ou seguimento. Trata-se de um estudo onde utilizaremos parte deste tecido tumoral armazenado para realizar estudos envolvendo moléculas e genes capazes de ajudar a identificar a agressividade do tumor e a possível chance de uma boa resposta ao tratamento com quimioterapia ou novos tratamentos dirigidos a moléculas e genes específicos. Também faz parte 
deste estudo analisar informações clínicas anotadas em seu prontuário médico e laudos dos exames que a Sra realizou antes, durante e após o término do seu tratamento.

Como benefício geral, gostaríamos de informar que estes resultados podem vir a ajudar outros pacientes e a própria equipe médica a entender de forma mais precisa qual paciente realmente terá uma boa resposta com redução do tumor usando este tipo de tratamento e conhecer possíveis alvos para tratamentos dirigidos.

Informamos também que não será realizada nenhuma outra coleta de material biológico (sangue ou tecido tumoral), que não será administrado nenhuma outra medicação, ou seja, que não haverá qualquer intervenção com a Sra ou alteração em seu tratamento.

A sua participação em nosso estudo é voluntária, portanto não será dada nenhuma ajuda financeira e também não será cobrada nenhuma taxa. Informamos que esta pesquisa não promoverá nenhum risco adicional a Sra ou ao seu tratamento.

É importante lembrar que este é apenas um convite e, caso a Sra aceite participar deste estudo, informamos que a Sra poderá desistir a qualquer momento, sem que isto interfira no atendimento ou no tratamento que a Sra esteja recebendo.

Destacamos que manteremos o sigilo de todas as informações e resultados obtidos no sentido de preservar sua identidade. Asseguramos que a Sra não será identificada, pois utilizaremos códigos para a sua identificação Os resultados e conclusões cientificas obtidas através deste estudo serão divulgadas exclusivamente nos meios científicos e acadêmicos.

Garantimos responder a qualquer dúvida ou esclarecimentos antes ou durante a pesquisa. Garantimos a assistência e acompanhamento neste hospital em casos de danos relacionados a este estudo. Caso a Sra se sinta prejudicada devido a sua participação nesta pesquisa, você tem o direito a indenização conforme as leis vigentes no país.

Caso concorde em participar do estudo, a Sra juntamente com o pesquisador assinarão este documento que está em duas vias. Uma delas é sua e a outra é do pesquisador responsável.

Desde já, agradecemos sua participação em nosso estudo.

$\mathrm{Eu}$,

anos, Reg. $\mathrm{HC} \mathrm{n}^{\mathrm{o}}$ aceito participar de forma livre e esclarecida do estudo: Projeto de estudo: Perfil Molecular do Carcinoma de células Claras de Ovário e sua correlação clínica na experiência de três instituições, estando de acordo com as condições do mesmo. 
Nome do participante:

Assinatura do participante:

Data:

Nome do Pesquisador:

Assinatura do pesquisador:

Data:

1

\section{Testemunha 1:}

Nome:

Assinatura:

Data:

1

\section{Testemunha 2:}

Nome:

Assinatura:

Data:

Ribeirão Preto, de de 


\section{HOSPITAL DAS CLÍNICAS DA
FACULDADE DE MEDICINA DE Q Plotoforma
RIBEIRÃO PRETO DA USP -}

\section{PARECER CONSUBSTANCIADO DO CEP}

\section{DADOS DO PROJETO DE PESQUISA}

Título da Pesquisa: Projeto de estudo: Perfil Molecular do Carcinoma de células Claras de Ovário e sua correlação clínica na experiência de três instituições.

Pesquisador: Mariana de Paiva Batista

Área Temática: Pesquisas com coordenação e/ou patrocínio originados fora do Brasil, excetuadas aquelas com copatrocínio do Governo Brasileiro;

Versão: 2

CAAE: 42441915.3 .0000 .5440

Instituição Proponente: Hospital das Clínicas da Faculdade de Medicina de Ribeirão Preto da USP -

Patrocinador Principal: Financiamento Próprio

\section{DADOS DO PARECER}

Número do Parecer: 1.187.347

Data da Relatoria: 02/07/2015

\section{Apresentação do Projeto:}

Trata-se de projeto de pesquisa a ser desenvolvido no HCFMRP-USP com instituição coparticipante (AC Camargo) e com cooperação estrangeira (Espanha).

Os pesquisadores envolvidos são: Mariana de Paiva Batista, Andrés Poveda Velasco, José Antonio Lopez, Guilherme Urano de Carvalho Machado, Antônio César Mendes Santiago, Cristiane Alves Mendes, Daniel Tiezzi, Jurandyr Moreira de Andrade, ; Eduardo Rego, Salvador Blanch, Ignacio Romero, Carmen Illueca Pedro Mallol Rosello, Fernando Augusto Soares, Glauco Baiocchi Neto, Louise de Brot, Alexandre Andre B.A. da Costa.

\section{1) Resumo}

Introdução: O Carcinoma de ovário compreende um grupo de neoplasias heterogêneo de elevada incidência, morbidade e mortalidade em todo o mundo. $\mathrm{O}$ tratamento considerado padrão consiste na ressecção cirúrgica ótima para todos os casos, independente do tipo histológico, seguido de quimioterapia adjuvante baseada em platina. Apesar do tratamento padrão, um número considerável de pacientes apresentará recorrência de doença e aproximadamente $50 \%$ terão óbito relacionado a ela. O Carcinoma de Células Claras (CCC) é

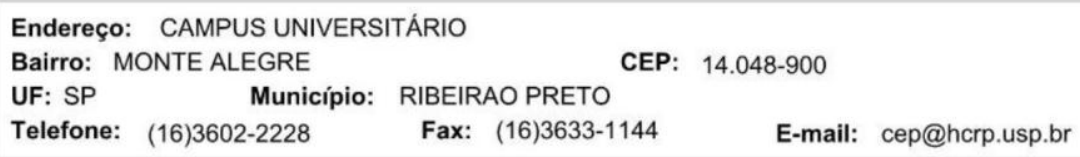




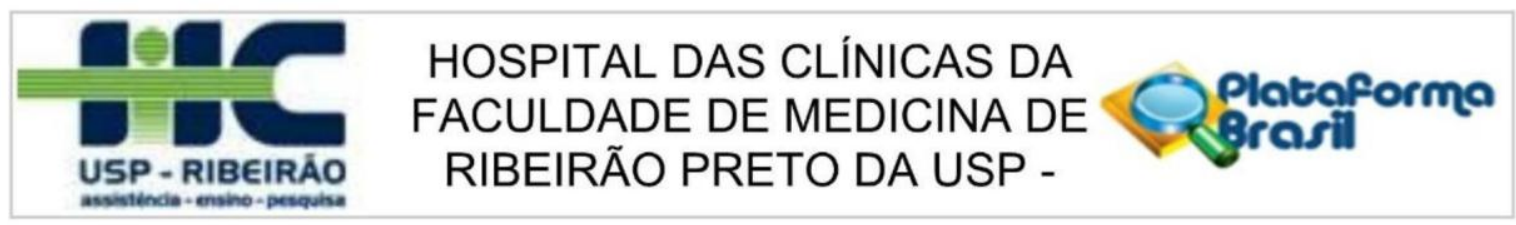

Continuação do Parecer: 1.187.347

considerado uma entidade única dentre os demais subtipos, em decorrência de suas características clínicas e patofisiológicas peculiares.

A biologia molecular e genômica do CCC, não completamente elucidada, ainda permanecem menos compreendidas que a biologia dos outros tumores epiteliais de ovário de alto grau.

Materiais e métodos: A fim de fornecer dados que possam beneficiar futuros pacientes,

realizaremos a revisão de prontuários e a análise molecular de amostras de carcinoma de ovário de células claras diagnosticados em 3 conhecidos centros de oncologia - Instituto Valenciano de Oncologia Espanha, Hospital das Clínicas da Faculdade de Medicina de Ribeirão Preto e Hospital AC Camargo. Objetivos: Pretendemos subsidiar a caracterização do comportamento biológico desta neoplasia e a identificação de possiveis alvos para novas linhas de tratamento.

\section{Objetivo da Pesquisa:}

Respaldados pelas evidências apresentadas, pretendemos: - Definir as características clínicas predominantes dos pacientes portadores de CCC em

uma população ampla e as comparar com dados da literatura atual. - Identificar nesta população a ocorrência do distinto perfil molecular do CCC já

descrito. - Avaliar a correspondência entre o perfil molecular e o comportamento clínico distinto observado nos CCC, especialmente a ocorrência de

metástases ósseas, eventos tromboembólicos e taxas de resposta a primeira linha de quimioterapia baseada em platina e taxano.

\section{Avaliação dos Riscos e Benefícios:}

Riscos: Tendo em consideração o fato de que o projeto será realizado utilizando a revisão de prontuários e a realização de exames moleculares em blocos de parafina, consideramos o mesmo com potencial mínimo de riscos. A fim de minimizar estes riscos nos concerne à manutenção do sigilo e a não exposição dos pacientes. Resultados relevantes serão divulgados apenas em revistas cientificas sem que a identidade dos pacientes seja revelada.

Benefícios: Esperamos acrescentar conhecimentos à cerca da fisiopatologia do carcinoma de ovário de células claras, levando a um melhor entendimento da relação entre seu perfil molecular e seu comportamento clínico, evidenciando perfis moleculares correlacionados com a evolução para metástases ósseas. Nosso estudo poderia contribuir para a pesquisa de potenciais alvos moleculares especificos para este subtipo histológico.

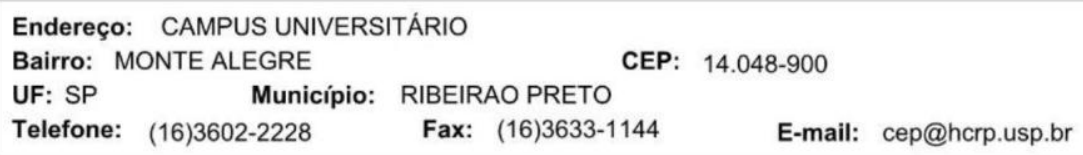




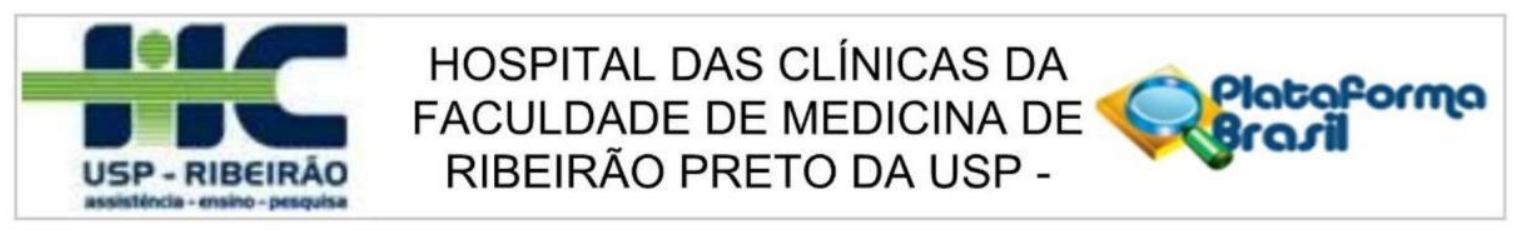

Continuação do Parecer: 1.187.347

\section{Comentários e Considerações sobre a Pesquisa:}

Trata-se de estudo retrospectivo com a revisando os prontuários médicos provindos de três conhecidos centros de tratamento e pesquisa em oncologia, um deles na Espanha (Área Clínica de Oncologia Ginecologica of the Instituto Valenciano de Oncologia) e os outros dois no Brasil (Divisão de Oncologia Ginecológica do Hospital das Clínicas da Faculdade de Medicina de Ribeirão Preto da Universidade de São Paulo e Divisão de Oncologia Ginecológica do Hospital AC Camargo), buscamos identificar casos de Carcinoma de Ovário do tipo histológico Células Claras, tamanho amostral de 40 casos, e identificá-los segundo as seguintes características clínicas:

- idade e estadiamento ao diagnóstico

- etnia (asiática ou não asiática)

- história de endometriose

- ocorrência de eventos tromboembólicos

- ocorrência de metástases ósseas

- Sobrevida Livre de Progressão (avaliando a resistência a platina e taxano como esquema adjuvante ou de primeira linha paliativa); definiremos resistência como ocorrência de progressão de doença durante a quimioterapia ou nos primeiros 6 meses após fim do tratamento quimioterápico. - Sobrevida Global As amostras histológicas passarão por estudo molecular e imunohistoquímico para a definição das seguintes características moleculares:

2a.) Imunohistoquímicas:

- Expressão de HNF1B; WT1; ER; PR; p53;

- Expressão de MLH1, MSH2, MSH6, PMS2 e ALDH1.

2b.) Análise genética:

- mutações de ARID1A; PIK3CA e MSI

- variação no número de cópias de CDKN2A/B, ZNF217

A análise destas características e sua correlação com o perfil genético dariam suporte à hipótese de provável relação entre elas.

Será solicitada junto aos comitês de ética das instituições envolvidas a liberação do termo de consentimento, por se tratar de estudo realizado em pacientes em sua maioria já falecidas ou com perda de seguimento. Os dados clínicos serão recolhidos em prontuários físicos dos três centros participantes com a colaboração destas instituições e dos pesquisadores envolvidos. Tais revisões de prontuários e coletas de dados estão autorizadas pelos responsáveis cabiveis.

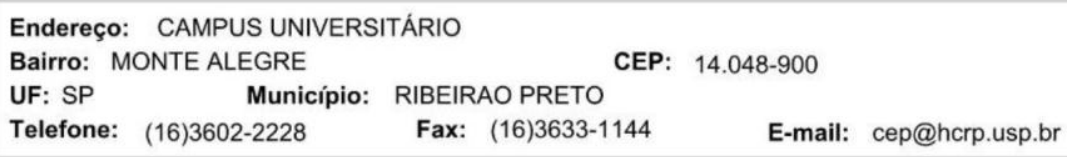




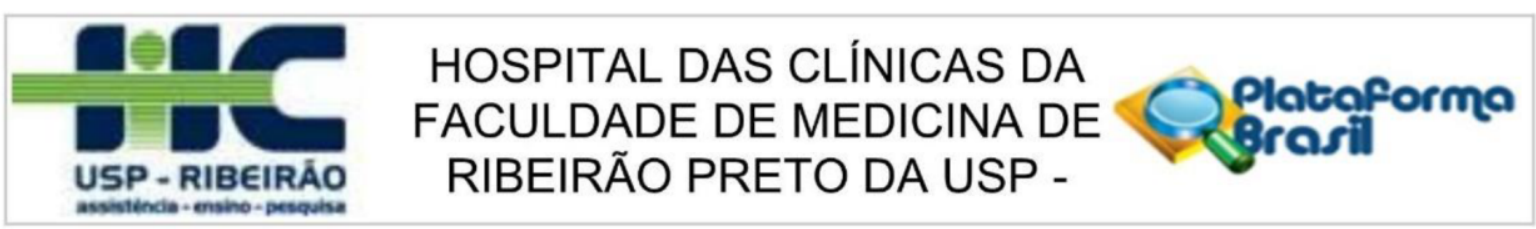

Continuação do Parecer: 1.187.347

As amostras histológicas passarão por estudo molecular e imunohistoquímico em cooperação entre os centros participantes e com a autorização dos responsáveis por estas. As amostras histológicas pertencentes ao HCFMRP estão arquivadas no Serviço de Anatomia Patológica deste hospital e serão utilizadas mediante a autorização de seu responsável. Autorização anexada.

\section{Considerações sobre os Termos de apresentação obrigatória:}

Não há.

\section{Recomendações:}

Conclusões ou Pendências e Lista de Inadequações:

Diante do exposto e à luz da Resolução CNS 466/2012, o projeto de pesquisa versão 1.1 de 12.06.15, assim como a dispensa do Termo de Consentimento Livre e Esclarecido, podem ser enquadrados na categoria APROVADO.

\section{Situação do Parecer:}

Aprovado

Necessita Apreciação da CONEP:

Sim

Considerações Finais a critério do CEP:

Projeto Aprovado: Tendo em vista a legislação vigente, devem ser encaminhados ao CEP, relatórios parciais anuais referentes ao andamento da pesquisa e relatório final ao término do trabalho. Qualquer modificação do projeto original deve ser apresentada a este CEP em nova versão, de forma objetiva e com justificativas, para nova apreciação.

O presente projeto, seguiu nesta data para análise da CONEP e só tem o seu início autorizado após a aprovação pela mesma.

RIBEIRAO PRETO, 17 de Agosto de 2015

Assinado por:
MARCIA GUIMARÃES VILLANOVA

(Coordenador)

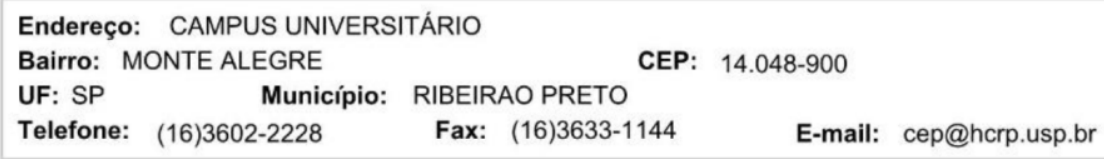


A.C.Camargo

Cancer Center

\section{FUNDAÇÃO ANTÔNIO \\ PRUDENTE - A.C. CAMARGO CANCER CENTER}

\section{PARECER CONSUBSTANCIADO DO CEP}

Elaborado pela Instituição Coparticipante

\section{DADOS DO PROJETO DE PESQUISA}

Título da Pesquisa: Projeto de estudo: Perfil Molecular do Carcinoma de células Claras de Ovário e sua correlação clínica na experiência de três instituições.

Pesquisador: Mariana de Paiva Batista

Área Temática: Pesquisas com coordenação e/ou patrocínio originados fora do Brasil, excetuadas aquelas com copatrocínio do Governo Brasileiro;

Versão: 2

CAAE: 42441915.3 .3001 .5432

Instituição Proponente: FUNDACAO ANTONIO PRUDENTE

Patrocinador Principal: FUNDACAO DE AMPARO A PESQUISA DO ESTADO DE SAO PAULO

\section{DADOS DO PARECER}

\section{Número do Parecer: 3.759 .823}

\section{Apresentação do Projeto:}

Foi enviado para o conhecimento deste Comitê de Ética em Pesquisa uma carta com respostas aos questionamentos referentes ao projeto "Perfil Molecular do Carcinoma de células Claras de Ovário e sua correlação clínica na experiência de três instituições".

\section{Objetivo da Pesquisa:}

O projeto busca:

- Definir as características clínicas predominantes dos pacientes portadores de Carcinoma de células Claras de Ovário em uma população ampla e as comparar com dados da literatura atual.

- Identificar nesta população a ocorrência do distinto perfil molecular do Carcinoma de células Claras de Ovário já descrito.

- Avaliar a correspondência entre o perfil molecular e o comportamento clínico distinto observado nos Carcinoma de células Claras de Ovário, especialmente a ocorrência de metástases ósseas, eventos tromboembólicos e taxas de resposta a primeira linha de quimioterapia baseada em platina e taxano.

\section{Avaliação dos Riscos e Benefícios:}

Os pesquisadores mencionam:

Endereço: Rua Professor Antônio Prudente, 211

Bairro: Liberdade

UF: SP Município: SAO PAULO

Telefone: (11)2189-5020 Fax: (11)2189-5020

CEP: $01.509-900$ 


\section{A.C.Camargo} Cancer Center

\section{FUNDAÇÃO ANTÔNIO PRUDENTE - A.C. CAMARGO CANCER CENTER}

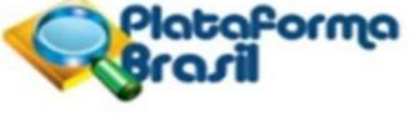

Continuação do Parecer: 3.759 .823

"Tendo em consideração o fato de que o projeto será realizado utilizando a revisão de prontuários e a realização de exames moleculares em blocos de parafina, consideramos o mesmo com potencial mínimo de riscos. A fim de minimizar estes riscos nos concerne à manutenção do sigilo e a não exposição dos pacientes. Resultados relevantes serão divulgados apenas em revistas cientificas sem que a identidade dos pacientes seja revelada.

Benefícios:

Esperamos acrescentar conhecimentos à cerca da fisiopatologia do carcinoma de ovário de células claras, levando a um melhor entendimento da relação entre seu perfil molecular e seu comportamento clínico, evidenciando perfis moleculares correlacionados com a evolução para metástases ósseas. Nosso estudo poderia contribuir para a pesquisa de potenciais alvos moleculares específicos para este subtipo histológico."

\section{Comentários e Considerações sobre a Pesquisa:}

Não há considerações referentes ao projeto de pesquisa

\section{Considerações sobre os Termos de apresentação obrigatória:}

Todas demais alterações solicitadas foram incluídas neste projeto.

Entretanto, o projeto Versão 1.5 de 17.09 .19 foi enviado para este Comitê com o título "Projeto de estudo: Perfil Molecular do Carcinoma de células Claras de Ovário e sua correlação clínica na experiência de quatro instituições". Toda documentação apresenta como titulo do projeto "Projeto de estudo: Perfil Molecular do Carcinoma de células Claras de Ovário e sua correlação clínica na experiência de três instituições.".

\section{Recomendações:}

É solicitado aos pesquisadores a alteraração do titulo do projeto enviado ao Comitê de Ética em Pesquisa

\section{Conclusões ou Pendências e Lista de Inadequações:}

Não há pendências com relação aos documentos enviados. Todas as inadequações e/ou dúvidas referentes ao projeto, questionadas anteriormente por este Comitê, foram ajustadas e/ou respondidas.

\section{Considerações Finais a critério do CEP:}

Este Comitê considera o projeto aprovado. Entretanto é solicitado ao pesquisador que faça a

Endereço: Rua Professor Antônio Prudente, 211

Bairro: Liberdade

UF: SP Município: SAO PAULO

Telefone: (11)2189-5020

CEP: $\quad 01.509-900$
Fax: (11)2189-5020
E-mail: cep hcancer@accamargo.org.br 


\section{accomente Cancer Center \\ FUNDAÇÃO ANTÔNIO PRUDENTE - A.C. CAMARGO CANCER CENTER}

Continuação do Parecer: 3.759 .823

alteração do título do projeto conforme especificado e também faça as atualizações necessárias na plataforma brasil.

Nota: Informações a respeito do andamento do referido projeto deverão ser encaminhadas ao CEP dentro de 06 meses a partir desta data em relatório (modelo CEP).

Este parecer foi elaborado baseado nos documentos abaixo relacionados:

\begin{tabular}{|c|c|c|c|c|}
\hline Tipo Documento & Arquivo & Postagem & Autor & Situação \\
\hline $\begin{array}{l}\text { Informações Básicas } \\
\text { do Projeto }\end{array}$ & $\begin{array}{l}\text { PB_INFORMAÇÕES_BÁSICAS_DO_P } \\
\text { ROJETO 675964.pdf }\end{array}$ & $\begin{array}{c}23 / 09 / 2019 \\
10: 42: 02\end{array}$ & & Aceito \\
\hline Outros & Carta_Resposta_2019_09_04_AA.pdf & $\begin{array}{c}23 / 09 / 2019 \\
10: 41: 00\end{array}$ & $\begin{array}{l}\text { Mariana de Paiva } \\
\text { Batista } \\
\end{array}$ & Aceito \\
\hline Outros & 13InstCop3.PDF & $\begin{array}{c}23 / 09 / 2019 \\
10: 21: 53\end{array}$ & $\begin{array}{l}\text { Mariana de Paiva } \\
\text { Batista }\end{array}$ & Aceito \\
\hline Orçamento & 09Orcamento.pdf & $\begin{array}{c}23 / 09 / 2019 \\
10: 20: 01\end{array}$ & $\begin{array}{l}\text { Mariana de Paiva } \\
\text { Batista }\end{array}$ & Aceito \\
\hline Cronograma & 09Cronograma.pdf & $\begin{array}{l}23 / 09 / 2019 \\
10: 19: 34\end{array}$ & $\begin{array}{l}\text { Mariana de Paiva } \\
\text { Batista }\end{array}$ & Aceito \\
\hline Outros & Carta_Prof_Rego_ao_Comite.PDF & $\begin{array}{c}23 / 09 / 2019 \\
09: 42: 50\end{array}$ & $\begin{array}{l}\text { Mariana de Paiva } \\
\text { Batista }\end{array}$ & Aceito \\
\hline $\begin{array}{l}\text { Projeto Detalhado / } \\
\text { Brochura } \\
\text { Investigador } \\
\end{array}$ & $\begin{array}{l}\text { Projeto_versao_1_5_de_17_09_19_com } \\
\text {-alteracoes_destacadas.pdf }\end{array}$ & $\begin{array}{c}23 / 09 / 2019 \\
09: 39: 02\end{array}$ & $\begin{array}{l}\text { Mariana de Paiva } \\
\text { Batista }\end{array}$ & Aceito \\
\hline \begin{tabular}{|l} 
Declaração de \\
Pesquisadores
\end{tabular} & 13InstCop2.PDF & $\begin{array}{c}23 / 07 / 2019 \\
12: 19: 59\end{array}$ & $\begin{array}{l}\text { Mariana de Paiva } \\
\text { Batista }\end{array}$ & Aceito \\
\hline \begin{tabular}{|l} 
Declaração de \\
Pesquisadores
\end{tabular} & Formularioccc.pdf & $\begin{array}{c}16 / 07 / 2019 \\
08: 22: 02\end{array}$ & $\begin{array}{l}\text { Mariana de Paiva } \\
\text { Batista }\end{array}$ & Aceito \\
\hline Orçamento & Orcamento.pdf & $\begin{array}{c}09 / 04 / 2019 \\
16: 21: 53 \\
\end{array}$ & $\begin{array}{l}\text { Mariana de Paiva } \\
\text { Batista } \\
\end{array}$ & Aceito \\
\hline $\begin{array}{l}\text { TCLE / Termos de } \\
\text { Assentimento / } \\
\text { Justificativa de } \\
\text { Ausência }\end{array}$ & 05TCLE.pdf & $\begin{array}{l}08 / 04 / 2019 \\
12: 52: 23\end{array}$ & $\begin{array}{l}\text { Mariana de Paiva } \\
\text { Batista }\end{array}$ & Aceito \\
\hline $\begin{array}{l}\text { Declaração de } \\
\text { Pesquisadores }\end{array}$ & 15MatBiol.pdf & $\begin{array}{c}08 / 04 / 2019 \\
12: 48: 51\end{array}$ & $\begin{array}{l}\text { Mariana de Paiva } \\
\text { Batista }\end{array}$ & Aceito \\
\hline $\begin{array}{l}\text { Declaração de } \\
\text { Pesquisadores }\end{array}$ & 13InstCop.pdf & $\begin{array}{c}08 / 04 / 2019 \\
12: 47: 30\end{array}$ & $\begin{array}{l}\text { Mariana de Paiva } \\
\text { Batista } \\
\end{array}$ & Aceito \\
\hline \begin{tabular}{|l} 
Declaração de \\
Pesquisadores
\end{tabular} & 06Dados.pdf & $\begin{array}{c}08 / 04 / 2019 \\
12: 45: 50\end{array}$ & $\begin{array}{l}\text { Mariana de Paiva } \\
\text { Batista }\end{array}$ & Aceito \\
\hline $\begin{array}{l}\text { Declaração de } \\
\text { Pesquisadores }\end{array}$ & 04TermoCompromisso.pdf & $\begin{array}{c}08 / 04 / 2019 \\
12: 41: 09 \\
\end{array}$ & $\begin{array}{l}\text { Mariana de Paiva } \\
\text { Batista } \\
\end{array}$ & Aceito \\
\hline Declaração de & 14CVs.pdf & $08 / 04 / 2019$ & Mariana de Paiva & Aceito \\
\hline
\end{tabular}

Endereço: Rua Professor Antônio Prudente, 211

Bairro: Liberdade

UF: SP Município: SAO PAULO

Telefone: (11)2189-5020 Fax: (11)2189-5020 E-mail: cep hcancer@accamargo.org.br 


\section{A.C.Camargo Cancer Center \\ FUNDAÇÃO ANTÔNIO PRUDENTE - A.C. CAMARGO CANCER CENTER}

Continuação do Parecer: 3.759 .823

\begin{tabular}{|c|c|c|c|c|}
\hline Pesquisadores & 14CVs.pdf & $12: 15: 57$ & Batista & Aceito \\
\hline $\begin{array}{l}\text { Declaração de } \\
\text { Pesquisadores }\end{array}$ & 08Cronograma.pdf & $\begin{array}{c}08 / 04 / 2019 \\
12: 15: 25 \\
\end{array}$ & $\begin{array}{l}\text { Mariana de Paiva } \\
\text { Batista } \\
\end{array}$ & Aceito \\
\hline $\begin{array}{l}\text { Declaração de } \\
\text { Instituição e } \\
\text { Infraestrutura }\end{array}$ & 06BInfraoc.pdf & $\begin{array}{c}27 / 03 / 2019 \\
12: 27: 48\end{array}$ & $\begin{array}{l}\text { Mariana de Paiva } \\
\text { Batista }\end{array}$ & Aceito \\
\hline $\begin{array}{l}\text { Declaração de } \\
\text { Instituição e } \\
\text { Infraestrutura }\end{array}$ & 06Ainfragineco.pdf & $\begin{array}{c}27 / 03 / 2019 \\
12: 27: 34\end{array}$ & $\begin{array}{l}\text { Mariana de Paiva } \\
\text { Batista }\end{array}$ & Aceito \\
\hline $\begin{array}{l}\text { Declaração de } \\
\text { Pesquisadores }\end{array}$ & $\begin{array}{l}\text { 12PB_PARECER_CONSUBSTANCIAD } \\
\text { O CONEP } 2630745 \text { E1.pdf } \\
\end{array}$ & $\begin{array}{c}27 / 03 / 2019 \\
12: 27: 24 \\
\end{array}$ & $\begin{array}{l}\text { Mariana de Paiva } \\
\text { Batista } \\
\end{array}$ & Aceito \\
\hline $\begin{array}{l}\text { Declaração de } \\
\text { Pesquisadores }\end{array}$ & 09CCienciaoc.pdf & $\begin{array}{c}27 / 03 / 2019 \\
12: 26: 57 \\
\end{array}$ & $\begin{array}{l}\text { Mariana de Paiva } \\
\text { Batista } \\
\end{array}$ & Aceito \\
\hline $\begin{array}{l}\text { Declaração de } \\
\text { Pesquisadores }\end{array}$ & 09Bcienciapato.pdf & $\begin{array}{c}27 / 03 / 2019 \\
12: 26: 42 \\
\end{array}$ & $\begin{array}{l}\text { Mariana de Paiva } \\
\text { Batista } \\
\end{array}$ & Aceito \\
\hline $\begin{array}{l}\text { Declaração de } \\
\text { Pesquisadores }\end{array}$ & 09Acienciagineco.pdf & $\begin{array}{c}27 / 03 / 2019 \\
12: 26: 28\end{array}$ & $\begin{array}{l}\text { Mariana de Paiva } \\
\text { Batista }\end{array}$ & Aceito \\
\hline $\begin{array}{l}\text { Declaração de } \\
\text { Pesquisadores }\end{array}$ & 01Folha_de_rosto_3.pdf & $\begin{array}{c}27 / 03 / 2019 \\
12: 11: 28 \\
\end{array}$ & $\begin{array}{l}\text { Mariana de Paiva } \\
\text { Batista } \\
\end{array}$ & Aceito \\
\hline Outros & Carta_resposta_CONEP_2.doc & $\begin{array}{c}21 / 01 / 2016 \\
09: 31: 27\end{array}$ & $\begin{array}{l}\text { Mariana de Paiva } \\
\text { Batista }\end{array}$ & Aceito \\
\hline Outros & Carta_resposta_CONEP_2.pdf & $\begin{array}{c}21 / 01 / 2016 \\
09: 31: 05 \\
\end{array}$ & $\begin{array}{l}\text { Mariana de Paiva } \\
\text { Batista }\end{array}$ & Aceito \\
\hline $\begin{array}{l}\text { Projeto Detalhado / } \\
\text { Brochura } \\
\text { Investigador }\end{array}$ & Projeto_versao_1_2_de_04_12_15.docx & $\begin{array}{c}21 / 01 / 2016 \\
09: 30: 37\end{array}$ & $\begin{array}{l}\text { Mariana de Paiva } \\
\text { Batista }\end{array}$ & Aceito \\
\hline Folha de Rosto & Folha_de_rosto_3.pdf & $\begin{array}{c}21 / 01 / 2016 \\
09: 22: 30 \\
\end{array}$ & $\begin{array}{l}\text { Mariana de Paiva } \\
\text { Batista } \\
\end{array}$ & Aceito \\
\hline Outros & Carta_resposta_CONEP_2.pdf & $\begin{array}{c}08 / 12 / 2015 \\
16: 22: 26 \\
\end{array}$ & $\begin{array}{l}\text { Mariana de Paiva } \\
\text { Batista }\end{array}$ & Aceito \\
\hline $\begin{array}{l}\text { Projeto Detalhado / } \\
\text { Brochura } \\
\text { Investigador }\end{array}$ & Projeto_versao_1_2_de_04_12_15.docx & $\begin{array}{c}08 / 12 / 2015 \\
16: 21: 57\end{array}$ & $\begin{array}{l}\text { Mariana de Paiva } \\
\text { Batista }\end{array}$ & Aceito \\
\hline Outros & \begin{tabular}{|l|} 
Termo_de_Responsabilidade_Estrangein \\
a Biorepositorio TRADUCAO.docx
\end{tabular} & $\begin{array}{c}08 / 12 / 2015 \\
15: 34: 54 \\
\end{array}$ & $\begin{array}{l}\text { Mariana de Paiva } \\
\text { Batista }\end{array}$ & Aceito \\
\hline Outros & $\begin{array}{l}\text { Termo_de_Responsabilidade_Estrangeir } \\
\text { a Biorrepositorio.pdf }\end{array}$ & $\begin{array}{c}08 / 12 / 2015 \\
15: 34: 07 \\
\end{array}$ & $\begin{array}{l}\text { Mariana de Paiva } \\
\text { Batista } \\
\end{array}$ & Aceito \\
\hline Outros & Acordo_Biorrepositorio_AC.docx & $\begin{array}{c}08 / 12 / 2015 \\
15: 33: 22\end{array}$ & $\begin{array}{l}\text { Mariana de Paiva } \\
\text { Batista }\end{array}$ & Aceito \\
\hline Outros & Acordo_Biorrepositorio_AC.pdf & $\begin{array}{c}08 / 12 / 2015 \\
14: 49: 07\end{array}$ & $\begin{array}{l}\text { Mariana de Paiva } \\
\text { Batista }\end{array}$ & Aceito \\
\hline Outros & Acordo_Biorrepositorio_IVO.docx & $\begin{array}{c}08 / 12 / 2015 \\
14: 48: 28 \\
\end{array}$ & $\begin{array}{l}\text { Mariana de Paiva } \\
\text { Batista } \\
\end{array}$ & Aceito \\
\hline Outros & Acordo_Biorrepositorio_IVO.pdf & $\begin{array}{c}08 / 12 / 2015 \\
14: 47: 52 \\
\end{array}$ & $\begin{array}{l}\text { Mariana de Paiva } \\
\text { Batista } \\
\end{array}$ & Aceito \\
\hline Outros & Acordo_Biorrepositorio_HC.docx & $\begin{array}{c}08 / 12 / 2015 \\
14: 47: 23 \\
\end{array}$ & $\begin{array}{l}\text { Mariana de Paiva } \\
\text { Batista }\end{array}$ & Aceito \\
\hline
\end{tabular}

Endereço: Rua Professor Antônio Prudente, 211

Bairro: Liberdade

UF: SP Município: SAO PAULO

CEP: $\quad 01.509-900$

Telefone: (11)2189-5020 Fax: (11)2189-5020 E-mail: cep_hcancer@accamargo.org.br 


\section{FUNDAÇÃO ANTÔNIO PRUDENTE - A.C. CAMARGO CANCER CENTER}

Continuação do Parecer: 3.759 .823

\begin{tabular}{|c|c|c|c|c|}
\hline Outros & Acordo_Biorrepositorio_HC.pdf & $\begin{array}{c}08 / 12 / 2015 \\
14: 46: 59\end{array}$ & $\begin{array}{l}\text { Mariana de Paiva } \\
\text { Batista }\end{array}$ & Aceito \\
\hline Outros & Declaracao_da_pesquisadora.docx & $\begin{array}{c}08 / 12 / 2015 \\
14: 46: 06\end{array}$ & $\begin{array}{l}\text { Mariana de Paiva } \\
\text { Batista }\end{array}$ & Aceito \\
\hline Outros & Declaracao_da_pesquisadora.pdf & $\begin{array}{c}08 / 12 / 2015 \\
14: 45: 38\end{array}$ & $\begin{array}{l}\text { Mariana de Paiva } \\
\text { Batista } \\
\end{array}$ & Aceito \\
\hline Outros & $\begin{array}{l}\text { Parecer_favoravel_ao_projeto_TRADUC } \\
\text { AO.docx }\end{array}$ & $\begin{array}{c}08 / 12 / 2015 \\
14: 44: 44\end{array}$ & $\begin{array}{l}\text { Mariana de Paiva } \\
\text { Batista } \\
\end{array}$ & Aceito \\
\hline Outros & Parecer_favoravel_ao_projeto.pdf & $\begin{array}{c}08 / 12 / 2015 \\
14: 44: 16\end{array}$ & $\begin{array}{l}\text { Mariana de Paiva } \\
\text { Batista }\end{array}$ & Aceito \\
\hline Outros & $\begin{array}{l}\text { Parecer_favoravel_ao_Termo_de_Biodis } \\
\text { ponibilidade TRADUCAO.docx }\end{array}$ & $\begin{array}{c}08 / 12 / 2015 \\
14: 43: 34\end{array}$ & $\begin{array}{l}\text { Mariana de Paiva } \\
\text { Batista } \\
\end{array}$ & Aceito \\
\hline Outros & $\begin{array}{l}\text { Parecer_favoravel_ao_Termo_de_Biodis } \\
\text { ponibilidade.pdf }\end{array}$ & $\begin{array}{c}08 / 12 / 2015 \\
14: 42: 25\end{array}$ & $\begin{array}{l}\text { Mariana de Paiva } \\
\text { Batista }\end{array}$ & Aceito \\
\hline Outros & $\begin{array}{l}\text { Termo_de_Biodisponibilidade_TRADUC } \\
\text { AO.doc }\end{array}$ & $\begin{array}{c}08 / 12 / 2015 \\
14: 38: 48\end{array}$ & $\begin{array}{l}\text { Mariana de Paiva } \\
\text { Batista }\end{array}$ & Aceito \\
\hline Outros & Termo_de_Biodisponibilidade.doc & $\begin{array}{c}08 / 12 / 2015 \\
14: 38: 20 \\
\end{array}$ & $\begin{array}{l}\text { Mariana de Paiva } \\
\text { Batista }\end{array}$ & Aceito \\
\hline Outros & Termo_de_Biodisponibilidade.pdf & $\begin{array}{c}08 / 12 / 2015 \\
14: 37: 38 \\
\end{array}$ & $\begin{array}{l}\text { Mariana de Paiva } \\
\text { Batista } \\
\end{array}$ & Aceito \\
\hline $\begin{array}{l}\text { TCLE / Termos de } \\
\text { Assentimento / } \\
\text { Justificativa de } \\
\text { Ausência } \\
\end{array}$ & Termo_de_Consentimento.doc & $\begin{array}{c}08 / 12 / 2015 \\
14: 36: 57\end{array}$ & $\begin{array}{l}\text { Mariana de Paiva } \\
\text { Batista }\end{array}$ & Aceito \\
\hline Outros & $\begin{array}{l}\text { Carta_de_Acordo_da_UPC_do_Hospital } \\
\text { das Clinicas.doc }\end{array}$ & $\begin{array}{c}08 / 12 / 2015 \\
14: 36: 14\end{array}$ & $\begin{array}{l}\text { Mariana de Paiva } \\
\text { Batista }\end{array}$ & Aceito \\
\hline Outros & $\begin{array}{l}\text { Carta_de_Acordo_da_UPC_do_Hospital } \\
\text { das Clinicas.pdf }\end{array}$ & $\begin{array}{c}08 / 12 / 2015 \\
14: 35: 45 \\
\end{array}$ & $\begin{array}{l}\text { Mariana de Paiva } \\
\text { Batista }\end{array}$ & Aceito \\
\hline Outros & $\begin{array}{l}\text { Carta_de_Acordo_do_Hospital_AC_Ca } \\
\text { margo.docx }\end{array}$ & $\begin{array}{c}08 / 12 / 2015 \\
14: 35: 18 \\
\end{array}$ & $\begin{array}{l}\text { Mariana de Paiva } \\
\text { Batista }\end{array}$ & Aceito \\
\hline Outros & $\begin{array}{l}\text { Carta_de_Acordo_do_Hospital_AC_Ca } \\
\text { margo.pdf }\end{array}$ & $\begin{array}{c}08 / 12 / 2015 \\
14: 34: 21\end{array}$ & $\begin{array}{l}\text { Mariana de Paiva } \\
\text { Batista }\end{array}$ & Aceito \\
\hline Outros & $\begin{array}{l}\text { CURRICULUM_VITAE_DA_PESQUISA } \\
\text { DORA.doc }\end{array}$ & $\begin{array}{c}08 / 12 / 2015 \\
14: 32: 51\end{array}$ & $\begin{array}{l}\text { Mariana de Paiva } \\
\text { Batista }\end{array}$ & Aceito \\
\hline Folha de Rosto & Folha_de_rosto_2.pdf & $\begin{array}{c}08 / 12 / 2015 \\
13: 13: 55\end{array}$ & $\begin{array}{l}\text { Mariana de Paiva } \\
\text { Batista }\end{array}$ & Aceito \\
\hline $\begin{array}{l}\text { Projeto Detalhado / } \\
\text { Brochura } \\
\text { Investigador }\end{array}$ & Projeto_versao_1_1_de_12_06_15.pdf & $\begin{array}{c}08 / 09 / 2015 \\
12: 30: 10\end{array}$ & $\begin{array}{l}\text { Mariana de Paiva } \\
\text { Batista }\end{array}$ & Aceito \\
\hline Outros & $\begin{array}{l}\text { Carta_autorizacao_da_Patologia_AC_C } \\
\text { amargo COM NOME.doc }\end{array}$ & $\begin{array}{c}08 / 09 / 2015 \\
12: 16: 43 \\
\end{array}$ & $\begin{array}{l}\text { Mariana de Paiva } \\
\text { Batista } \\
\end{array}$ & Aceito \\
\hline Outros & Carta_de_Acordo.doc & $\begin{array}{c}08 / 09 / 2015 \\
12: 13: 15\end{array}$ & $\begin{array}{l}\text { Mariana de Paiva } \\
\text { Batista }\end{array}$ & Aceito \\
\hline Outros & Formulario_SAME.xIs & $\begin{array}{c}08 / 09 / 2015 \\
12: 12: 53 \\
\end{array}$ & $\begin{array}{l}\text { Mariana de Paiva } \\
\text { Batista }\end{array}$ & Aceito \\
\hline Outros & $\begin{array}{l}\text { Carta_autorizacao_dados_clinicos_AC_ } \\
\text { Camargo.doc }\end{array}$ & $\begin{array}{c}08 / 09 / 2015 \\
12: 12: 21 \\
\end{array}$ & $\begin{array}{l}\text { Mariana de Paiva } \\
\text { Batista }\end{array}$ & Aceito \\
\hline
\end{tabular}

Endereço: Rua Professor Antônio Prudente, 211

Bairro: Liberdade

UF: SP Município: SAO PAULO

CEP: $\quad 01.509-900$

Telefone: (11)2189-5020 Fax: (11)2189-5020 E-mail: cep_hcancer@accamargo.org.br 


\section{A.C.Camargo \\ Cancer Center \\ FUNDAÇÃO ANTÔNIO PRUDENTE - A.C. CAMARGO CANCER CENTER}

Continuação do Parecer: 3.759 .823

\begin{tabular}{|c|c|c|c|c|}
\hline Outros & $\begin{array}{l}\text { Carta_autorizacao_da_Patologia_do_H } \\
\text { C.doc }\end{array}$ & $\begin{array}{l}08 / 09 / 2015 \\
12: 11: 25\end{array}$ & $\begin{array}{l}\text { Mariana de Paiva } \\
\text { Batista } \\
\end{array}$ & Aceito \\
\hline Outros & $\begin{array}{l}\text { Cartas_de_autorizacao_IVO_TRADUZI } \\
\text { DA.doc }\end{array}$ & $\begin{array}{l}08 / 09 / 2015 \\
12: 10: 36\end{array}$ & $\begin{array}{l}\text { Mariana de Paiva } \\
\text { Batista }\end{array}$ & Aceito \\
\hline Outros & Cartas_de_autorizacao_IVO.doc & $\begin{array}{c}08 / 09 / 2015 \\
12: 07: 24\end{array}$ & $\begin{array}{l}\text { Mariana de Paiva } \\
\text { Batista }\end{array}$ & Aceito \\
\hline Outros & Carta_resposta.doc & $\begin{array}{l}08 / 09 / 2015 \\
12: 06: 46\end{array}$ & $\begin{array}{l}\text { Mariana de Paiva } \\
\text { Batista }\end{array}$ & Aceito \\
\hline Folha de Rosto & $\begin{array}{l}\text { Folha_de_rosto_COM_ASSINATURA.pd } \\
f\end{array}$ & $\begin{array}{c}08 / 09 / 2015 \\
11: 58: 44\end{array}$ & $\begin{array}{l}\text { Mariana de Paiva } \\
\text { Batista }\end{array}$ & Aceito \\
\hline Outros & $\begin{array}{l}\text { Carta Cooperação Estrangeira - } \\
\text { TRADUZIDA.pdf }\end{array}$ & $\begin{array}{c}02 / 07 / 2015 \\
09: 35: 55\end{array}$ & & Aceito \\
\hline $\begin{array}{l}\text { Projeto Detalhado / } \\
\text { Brochura } \\
\text { Investiqador }\end{array}$ & Projeto versão 1.1 de 12.06.15.pdf & $\begin{array}{l}12 / 06 / 2015 \\
16: 29: 02\end{array}$ & & Aceito \\
\hline $\begin{array}{l}\text { Projeto Detalhado / } \\
\text { Brochura } \\
\text { Investiqador }\end{array}$ & Projeto.docx & $\begin{array}{l}27 / 02 / 2015 \\
12: 41: 06\end{array}$ & & Aceito \\
\hline Outros & solicitação de dispensa do TCLE.doc & $\begin{array}{l}23 / 01 / 2015 \\
13: 40: 10\end{array}$ & & Aceito \\
\hline Outros & $\begin{array}{l}\text { Orçamento Projeto Carcinoma de } \\
\text { Células Claras.docx }\end{array}$ & $\begin{array}{c}23 / 01 / 2015 \\
13: 04: 29\end{array}$ & & Aceito \\
\hline
\end{tabular}

\section{Situação do Parecer:}

Aprovado

Necessita Apreciação da CONEP:

Não

SAO PAULO, 11 de Dezembro de 2019

\section{Assinado por:}

Sandra Caires Serrano

(Coordenador(a))

Endereço: Rua Professor Antônio Prudente, 211

Bairro: Liberdade

UF: SP

Município: SAO PAULO

CEP: $\quad 01.509-900$

Telefone: (11)2189-5020

Fax: (11)2189-5020

E-mail: cep_hcancer@accamargo.org.br 


\section{COMISSÃO NACIONAL DE ÉTICA EM PESQUISA}

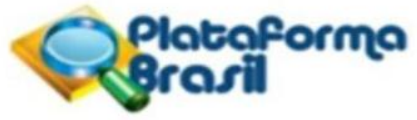

\section{PARECER CONSUBSTANCIADO DA CONEP}

\section{DADOS DO PROJETO DE PESQUISA}

Título da Pesquisa: Projeto de estudo: Perfil Molecular do Carcinoma de células Claras de Ovário e sua correlação clínica na experiência de três instituições.

Pesquisador: Mariana de Paiva Batista

Área Temática: Pesquisas com coordenação e/ou patrocínio originados fora do Brasil, excetuadas aquelas com copatrocínio do Governo Brasileiro;

Versão: 4

CAAE: 42441915.3 .0000 .5440

Instituição Proponente: Hospital das Clínicas da Faculdade de Medicina de Ribeirão Preto da USP -

Patrocinador Principal: FUNDACAO DE AMPARO A PESQUISA DO ESTADO DE SAO PAULO

\section{DADOS DO PARECER}

Número do Parecer: 1.440 .107

\section{Apresentação do Projeto:}

Introdução:

O Carcinoma de ovário compreende um grupo de neoplasias heterogêneo de elevada incidência, morbidade e mortalidade em todo o mundo. Sua incidência atinge cerca de 13.5/100.000 pacientes por ano em paises desenvolvidos. Histologicamente, o tipo epitelial é o mais comum (>95\%) seguido dos tipos estromal e germinativo. O tipo epitelial é subclassificado, em ordem de prevalência, em seroso, endometrióide, células claras e mucinoso. O tratamento considerado padrão consiste na ressecção cirúrgica ótima para todos os casos, independente do tipo histológico, seguido de quimioterapia adjuvante baseada em platina em estadios iniciais com alto risco de recaída (IA e IB sendo G3 ou células claras, IC e II) como para estadios avançados (III e IV) - NCCN. Apesar do tratamento padrão, um número considerável de pacientes apresentará recorrência de doença e aproximadamente $50 \%$ terão óbito relacionado a ela. Comumente a disseminação ocorre na cavidade abdominal para o peritôneo e via linfática. A disseminação hematogênica é incomum, preferencialmente para fígado e pulmões e raramente para ossos. O Carcinoma de Células Claras é considerado uma entidade única dentre os demais subtipos, em decorrência de suas características clínicas e patofisiológicas peculiares. Estes dados motivam a

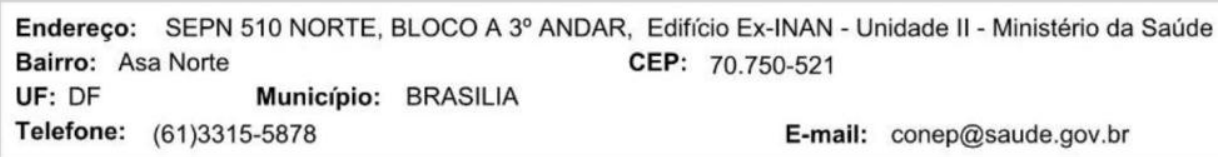




\section{COMISSÃO NACIONAL DE ÉTICA EM PESQUISA}

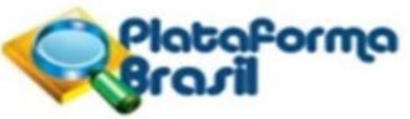

Continuação do Parecer: 1.440 .107

realização de pesquisas que subsidiem a caracterização do comportamento biológico desta neoplasia e a identificação de possiveis alvos para novas linhas de tratamento. Neste contexto carcinoma epitelial de ovário é dividido em dois grupos, baseado em características morfológicas, genéticas e imunohistoquímicas. Tipo I: tumores de células claras, tumores de baixo grau dos tipos endometrióide, mucinoso, seroso e carcinoma transicional. Comumente se desenvolvem de lesões precursoras e de forma lenta. Mutações comuns em diferentes genes são partilhadas e podem ser identificadas: KRAS, BRAF, PTEN, PIK3CA, ARID1A, ERBB2, CTNNB1 e PPP2R1A. Tipo II: carcinoma seroso de alto grau, carcinoma indiferenciado e tumores mesodérmicos malignos mistos (carcinosarcoma). Comumente se originam do epitélio distal das tubas uterinas e apresentam comportamento agressivo. Mutações em TP53 são identificadas em $80 \%$ destes casos, assim como o são altos niveis de instabilidade genética. O Carcinoma de Células Claras é considerado uma entidade única dentre os demais subtipos, em decorrência de suas características clínicas e patofisiológicas peculiares: a. Sua incidência global varia entre 5 e 25\%. Na Europa e América do Norte está em torno $1-12 \%$, enquanto no Japão alcança $15-25 \%$, fato que sugere predisposição da população japonesa a este tipo de tumor. b. Costuma afetar mulheres mais jovens que as afetadas pelo tipo seroso mais comum [média de idade ao diagnóstico 55 vs 64 anos] e a maioria são diagnosticadas em estadios iniciais (I / II) [47-95\%] (11). c. Frequentemente se apresenta como massa pélvica de grande volume, raramente bilateral. d. Apresentam pobre resposta a quimioterapia convencional baseada em platina, embora novos estudos vêm demonstrado sobrevida global e sobrevida livre de progressão semelhantes ao tipo seroso, quando diagnosticado em estadios iniciais. e. Incidência elevada de eventos tromboembólicos (>40\% dos casos) e associação com endometriose. f. Ocorrência de Hipercalcemia é mais frequentemente observada. A respeito do envolvimento ósseo, estudos demonstram que a ocorrência de metástases ósseas em carcinomas de ovário epiteliais é rara, 0.1- 0.12\% conforme repostado em algumas séries de casos. Todavia, estudo asiático reportou 103 casos de carcinoma de ovário aonde se apresentou envolvimento ósseo em 4 casos, nenhum deles provindos de CCC. Estes casos culminaram em baixas taxas de sobrevida global (8 meses). Um estudo relatou 26 casos de metastases ósseas de carcinoma de ovário, com uma incidência de $0.82 \%$ com envolvimento mais frequente de pelve e vértebras. Estudo alemão relatou incidência de metástases ósseas em carcinoma de ovário em 1.5\% dos casos. Correlacionou ainda o intervalo de tempo entre o desenvolvimento destas metástases e o diagnóstico do câncer com o prognóstico. Caso ocorra em intervalo menor que 12 meses apresenta media de sobrevida global entre 11.2 meses, caso ocorra em intervalo > 12 meses a sobrevida global alcança 78.4 meses. A biologia

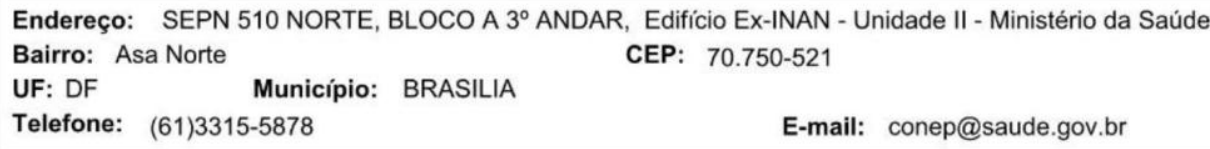




\section{COMISSÃO NACIONAL DE ÉTICA EM PESQUISA}

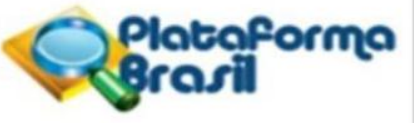

Continuação do Parecer: 1.440 .107

molecular e genômica do CCC, não completamente elucidada, ainda permanece menos compreendida que a biologia dos outros tumores epiteliais de ovário de alto grau. Carcinomas de células claras frequentemente apresentam: Imunohistoquímica negativa em: receptores de estrógeno (ER), tumor Wilms 1 (WT1) e proteína 53 (p53) - caracterizando - o 'triplo negativo' - com uma baixa frequência de mutações BRCA 1 e 2 (13.2\% - câncer de ovário invasivo). Baixos níveis de instabilidade cromossômica e baixas taxas de proliferação cellular, com alta frequência de mutações da phosphoinositide 3- kinase catalytic alpha (PIK3CA mutações) estimadas em $40 \%$. Mutações truncadas e perda da expressão proteica do gene de supressão tumoral ARID1A, o qual é responsabilizado pela patologia envolvida entre endometriose contígua atípica e CCC, como evidenciado por um estudo,. Mutações em PP2R1A (7.1\%) e KRAS (4.7\%), como demonstrado pelo sequenciamento desenvolvido por Sanger em 42 casos confirmados de CCC (o qual também identificou mutações de ARID1A em $57 \%$ dos casos). Alta expressão celular de ALDH1. ALDH1 é um marcador de células tronco like e células inicializadoras, em carcinoma de ovário (CCC e adenocarcinoma seroso). O seu nível de expressão pode ser um novo biomarcador para predição de mau prognóstico, como descrito por uma pesquisa.

Hipótese:

- O comportamento clínico distinto do CCC pode ser observado em outras populações de pacientes.

- O perfil molecular descrito no CCC também está presente em populações distintas.

- O perfil molecular se correlaciona com o comportamento clínico distinto do CCC

Metodologia:

Revisando os prontuários médicos provindos de três conhecidos centros de tratamento e pesquisa em oncologia, um deles na Espanha (Área Clínica de Oncologia Ginecológica do Instituto Valenciano de Oncologia) e os outros dois no Brasil (Divisão de Oncologia Ginecológica do Hospital das Clínicas da Faculdade de Medicina de Ribeirão Preto da Universidade de São Paulo e Divisão de Oncologia Ginecológica do Hospital A.C. Camargo), buscamos identificar casos de Carcinoma de Ovário do tipo histológico Células Claras, tamanho amostral de 40 casos, e identificá-los segundo as seguintes características clínicas: - idade e estadiamento ao diagnóstico - etnia (asiática ou não asiática) - história de endometriose - ocorrência de eventos tromboembólicos - ocorrência de

Endereço: SEPN 510 NORTE, BLOCO A $3^{\circ}$ ANDAR, Edifício Ex-INAN - Unidade II - Ministério da Saúde Bairro: Asa Norte CEP: $70.750-521$

UF: DF Município: BRASILIA

Telefone: (61)3315-5878

E-mail: conep@saude.gov.br 


\section{COMISSÃO NACIONAL DE ÉTICA EM PESQUISA}

\section{Patabofome}

Continuação do Parecer: 1.440 .107

metástases ósseas - Sobrevida Livre de Progressão (avaliando a resistência a platina e taxano como esquema adjuvante ou de primeira linha paliativa); definiremos resistência como ocorrência de progressão de doença durante a quimioterapia ou nos primeiros 6 meses após fim do tratamento quimioterápico. Sobrevida Global - As amostras histológicas passarão por estudo molecular e imunohistoquímico para a definição das seguintes características moleculares: 2a) Imunohistoquímicas: - Expressão de HNF1B; WT1; ER; PR; p53; - Expressão de MLH1, MSH2, MSH6, PMS2 e ALDH1. 2b) Análise genética: - mutações de ARID1A; PIK3CA e MSI - variação no número de cópias de CDKN2A/B, ZNF217. A análise destas características e sua correlação com o perfil genético dariam suporte à hipótese de provável relação entre elas. Será solicitada junto aos comitês de ética das instituições envolvidas a liberação do termo de consentimento, por se tratar de estudo realizado em pacientes em sua maioria já falecidas ou com perda de seguimento.

Critérios de Inclusão/ Exclusão:

Critério de inclusão:

Após busca de casos de carcinoma de ovário de células claras nos centros de oncologia descritos, estimamos um tamanho amostral de cerca de 40 casos. Incluiremos em nosso projeto o estudo clínico e molecular de amostras de tumores cujos exames anatomo-patológicos revelem tumores deste subtipo histológico. Serão incluídas pacientes femininas e maiores de 18 anos.

\section{Critério de Exclusão:}

Serão excluidos os demais subtipos histológicos de carcinoma de ovário.

\section{Objetivo da Pesquisa:}

Objetivo Primário:

Respaldados pelas evidências apresentadas, pretendemos:

- Definir as características clínicas predominantes dos pacientes portadores de CCC em uma população ampla e as comparar com dados da literatura atual.

- Identificar nesta população a ocorrência do distinto perfil molecular do CCC já descrito.

Endereço: SEPN 510 NORTE, BLOCO A $3^{\circ}$ ANDAR, Edifício Ex-INAN - Unidade II - Ministério da Saúde Bairro: Asa Norte

UF: DF Município: BRASILIA

Telefone: (61)3315-5878 CEP: $70.750-521$

E-mail: conep@saude.gov.br 


\section{COMISSÃO NACIONAL DE ÉTICA EM PESQUISA}

Continuação do Parecer: 1.440 .107

- Avaliar a correspondência entre o perfil molecular e o comportamento clínico distinto observado nos CCC, especialmente a ocorrência de metástases ósseas, eventos tromboembólicos e taxas de resposta à primeira linha de quimioterapia baseada em platina e taxano.

Objetivo Secundário: Não há.

\section{Avaliação dos Riscos e Benefícios:}

Constam no projeto cadastrado na Plataforma Brasil:

Riscos:

Tendo em consideração o fato de que o projeto será realizado utilizando a revisão de prontuários e a realização de exames moleculares em blocos de parafina, consideramos o mesmo com potencial mínimo de riscos. A fim de minimizar estes riscos nos concerne à manutenção do sigilo e a não exposição dos pacientes. Resultados relevantes serão divulgados apenas em revistas cientificas sem que a identidade dos pacientes seja revelada.

Benefícios:

Esperamos acrescentar conhecimentos à cerca da fisiopatologia do carcinoma de ovário de células claras, levando a um melhor entendimento da relação entre seu perfil molecular e seu comportamento clínico, evidenciando perfis moleculares correlacionados com a evolução para metástases ósseas. Nosso estudo poderia contribuir para a pesquisa de potenciais alvos moleculares especificos para este subtipo histológico.

\section{Comentários e Considerações sobre a Pesquisa:}

Ver item "Conclusões ou Pendências e Listas de Inadequações".

Considerações sobre os Termos de apresentação obrigatória:

Ver item "Conclusões ou Pendências e Listas de Inadequações".

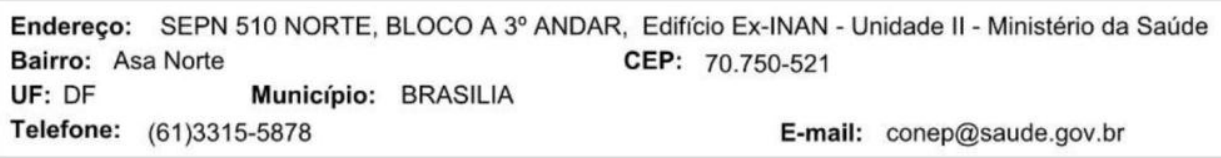




\section{COMISSÃO NACIONAL DE ÉTICA EM PESQUISA}

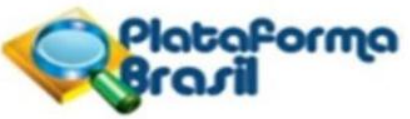

Continuação do Parecer: 1.440 .107

\section{Conclusões ou Pendências e Lista de Inadequações:}

Respostas ao Parecer Consubstanciado no: 1.308.356:

1 - Quanto ao Cronograma do Estudo: No documento intitulado "PB_INFORMAÇÕES_BÁSICAS_DO_PROJETO_458755.pdf", item "Cronograma de Execução", página 05 de 07, existe a informação de que a coleta de dados clínicos dos prontuários teria início em 07/04/2015. Levando-se em conta a informação apresentada, supõe-se que a pesquisa já teve início. Diante disso, solicitam-se esclarecimentos quanto à data de início do estudo (Norma Operacional CNS nº 001 de 2013 , item 3.3.f).

RESPOSTA: Tendo em mente que o cronograma citado foi enviado em uma primeira apresentação do projeto para valoração pela CONEP em Março de 2015, naquele momento tínhamos a ideia de realizar o projeto com o máximo esforço de tempo e colaboração, por isso planejávamos iniciar a coleta de dados em abril com a esperada aprovação do comitê. Como no momento atual, dezembro de 2015, ainda não temos a aprovação citada, reformulamos o cronograma na Plataforma Brasil e na página 9 (item 8) do projeto versão 1.2 de 04.12.15.

ANÁLISE: PENDÊNCIA ATENDIDA.

2 - No documento intitulado "Carta_de_Acordo.doc", lê-se: "Informo também que o pesquisador responsável e orientador possuem currículo Lattes.". Solicita-se esclarecimento se este projeto terá o objetivo de obtenção de titulo de pós-graduação (Stricto sensu ou Latu sensu) da Dra. Mariana de Paiva Batista e se o Dr. Jurandyr Moreira de Andrade será o orientador da pesquisadora neste projeto. Além disso, solicita-se apresentar o currículo atualizado da pesquisadora.

RESPOSTA: Os resultados do projeto exposto têm como um de seus objetivos maiores a obtenção de titulo de pós-graduação da Dra. Mariana de Paiva Batista tendo como orientador o Prof. Dr. Eduardo Magalhães Rego. O currículo atualizado da pesquisadora foi anexado à Plataforma Brasil.

ANÁLISE: PENDÊNCIA ATENDIDA.

3 - Em relação à equipe de pesquisa, há divergência entre os nomes cadastrados nas Informações Básicas do Projeto (Documento intitulado "PB_INFORMAÇÕES_BÁSICAS_DO_PROJETO_458755.pdf", postado em 08/09/2015) e no Projeto Detalhado (Documento intitulado "Projeto_versao_1_1_de_12_06_15.pdf", postado em 08/09/2015). Solicita-se relacionar as instituições que assinaram Carta de Anuência e os respectivos profissionais.

RESPOSTA: Alterado nas informações básicas detalhadas no Projeto versão 1.2 de 04.12 .15 e

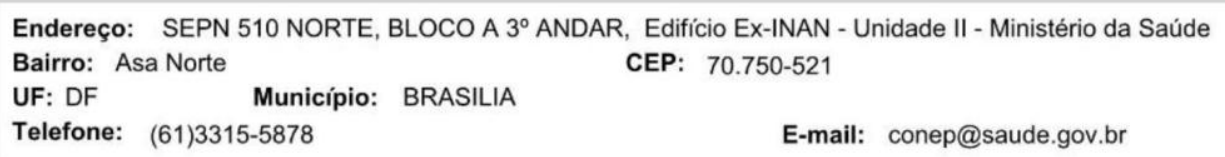




\section{COMISSÃO NACIONAL DE ÉTICA EM PESQUISA}

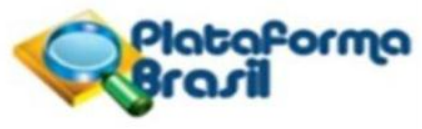

Continuação do Parecer: 1.440 .107

também na Plataforma Brasil os participantes envolvidos no projeto.

- HCFMRP - Eduardo Rego Magalhães, Mariana de Paiva Batista, Jurandyr Moreira de Andrade, Daniel Tiezzi, Antonio Cesar Mendes Santiago, Cristiane Alves Mendes, Guilherme Urano Carvalho Machado, Fernando Chaud, Fernanda Maris Peria.

- IVO- Andres Poveda, Ignacio Romero, Jose Antonio Lopez Guerrero, Carmen Illueca e Pedro Mallol.

- AC Camargo - Fernando Soares, Louise de Brot, Alexandre da Costa.

ANÁLISE: PENDÊNCIA ATENDIDA.

4 - Na Plataforma Brasil existe a informação de que o Hospital A. C. Camargo será instituição coparticipante. Conforme definição na Plataforma Brasil, "Instituição coparticipante é aquela na qual haverá o desenvolvimento de alguma fase/etapa da pesquisa E NÃO O PROCEDIMENTO COMPLETO DE PONTA A PONTA COMO DESCRITO NA PESQUISA." (Destaque nosso). Solicita-se, portanto, esclarecer quais etapas do estudo serão realizadas em cada centro do estudo (Hospital das Clínicas da Faculdade de Medicina de Ribeirão Preto, Hospital A. C. Camargo e Instituto Valenciano de Oncologia).

RESPOSTA: Detalhado cada um dos tópicos referentes a Materiais e Métodos no Projeto versão 1.2 de 04.12.15, página 5-6, item 5 de acordo com sua realização pelos respectivos centros.

ANÁLISE: PENDÊNCIA ATENDIDA.

5 - Quanto ao Orçamento/Financiamento do Estudo:

a) Na Folha de Rosto se observa a assinatura da própria pesquisadora responsável pelo estudo, Dra. Mariana de Paiva Batista, no campo "Patrocinador Principal". No documento intitulado "PB_INFORMAÇÕES_BÁSICAS_DO_PROJETO_458755.pdf", página 05 de 07, item "Orçamento Financeiro" foi apresentado o orçamento detalhado do estudo, com os custos de cada procedimento/etapa. Solicita-se esclarecimento quanto ao financiamento deste estudo, apresentando declaração datada e assinada pela instituição financiadora, exceto no caso de órgão de fomento, devendo apenas constar na Folha de Rosto a citação deste. Ressalta-se que, caso exista financiamento de fora do país, solicita-se adequar o projeto na Plataforma Brasil, incluindo-o na área temática "pesquisas com coordenação e/ou patrocínio originados fora do Brasil, excetuadas aquelas com copatrocínio do Governo Brasileiro (Resolução CNS n 466 de 2012, item

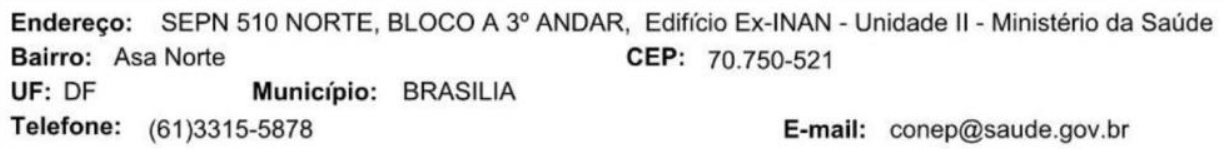




\section{COMISSÃO NACIONAL DE ÉTICA EM PESQUISA}

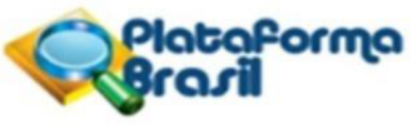

Continuação do Parecer: 1.440.107

IX.4.8).

RESPOSTA: Os procedimentos do projeto a serem realizados no HCFMRP serão financiados pelo órgão de fomento FAPESP no Processo 2013/08135-2 em Projeto do Centro de Terapia Celular que tem como coordenador o Dr. Tadeu Dimas Cavas e seu pesquisador o Dr. Eduardo Magalhães Rego. Sendo assim, citamos o órgão de fomento na Folha de Rosto como solicitado pela CONEP. Os procedimentos realizados no IVO serão financiados pelo próprio instituto já que fazem parte de técnica padrão de diagnóstico da instituição, coberta pelo governo espanhol. Ressaltamos que não existe um financiamento de fora do país somente participação, sendo que as análises em laboratório brasileiro serão custeadas pela FAPESP e no laboratório espanhol farão parte da rotina diagnóstica adotada no IVO.

ANÁLISE: PENDÊNCIA ATENDIDA.

b) No documento intitulado "Carta_de_Acordo.doc", lê-se: "O orçamento do presente projeto foi analisado pela equipe técnica da UPC antes da submissão ao Comitê e foi APROVADO.". Solicita-se a apresentação de documento com autorização do orçamento da pesquisa pela equipe técnica da UPC e da direção do HCFMRP-USP e do Hospital A. C. Camargo. Ressalta-se que ambas são instituições públicas (Hospital das Clínicas e Hospital A.C. Camargo) e os custos com a execução do projeto não deverão onerar o Sistema Único de Saúde (SUS).

RESPOSTA: Anexado a Plataforma Brasil a CARTA DE ACORDO DO HOSPITAL A.C. CAMARGO e CARTA DE ACORDO DA UPC DO HOSPITAL DAS CLÍNICAS. Vale destacar que o presente projeto tem caráter retrospectivo observacional, portanto não inclui intervenção, e que a pesquisa genética a ser realizada no Brasil será custeada pelo órgão de fomento FAPESP. Não há exames de qualquer natureza adicionais que onerem ao SUS brasileiro. Quanto aos exames a serem feitos na Espanha, esses fazem parte da rotina diagnóstica do IVO e, portanto também autorizados por seu diretor responsável.

Temos anexada na plataforma Brasil a aprovação do projeto pela Unidade de Pesquisa Clínica (UPC) do HCFMRP, setor desta instituição responsável pela pesquisa clínica realizada ali. Sendo assim, o projeto foi avaliado e aprovado pela UPC, estando implícita a anuência do HCFMRP.

ANÁLISE: PENDÊNCIA ATENDIDA.

6 - Quanto ao Projeto Detalhado, Versão 1.1 de 12/06/2015, documento intitulado "Projeto_versao_1_1_de_12_06_15.pdf", 08 páginas:

Endereço: SEPN 510 NORTE, BLOCO A $3^{\circ}$ ANDAR, Edifício Ex-INAN - Unidade II - Ministério da Saúde

Bairro: Asa Norte

UF: DF Município: BRASILIA

Telefone: (61)3315-5878 CEP: $70.750-521$

E-mail: conep@saude.gov.br 


\section{COMISSÃO NACIONAL DE ÉTICA EM PESQUISA}

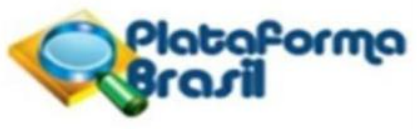

Continuação do Parecer: 1.440.107

a) Na página 05 de 08 , item " 5 . Materiais e Métodos", lê-se: "Será solicitada junto aos comitês de ética das instituições envolvidas a liberação do termo de consentimento, por se tratar de estudo realizado em pacientes em sua maioria já falecidas ou com perda de seguimento.". Solicita-se a apresentação de documento assinado e datado do Comitê de Ética na Espanha, autorizando a dispensa de consentimento. Deve-se atentar que dos pacientes vivos deve ser colhido o consentimento para uso de seus dados clínicos armazenados, conforme Carta CNS n 39 de 2011, para que eles tenham direito ao exercício da autonomia, um dos princípios da Bioética.

RESPOSTA: Solicitaremos o termo de consentimento das pacientes vivas quando obtivermos a aprovação deste Comitê e assim sermos aptos a revisar histórias e averiguar as sobreviventes. Anexado a Plataforma Brasil o TERMO DE CONSENTIMENTO LIVRE E ESCLARECIDO a ser solicitado e detalhada esta informação em Materiais e Métodos no Projeto versão 1.2 de 04.12.15, página 5, item 5.

Atendendo a solicitação encaminhamos o termo de biodisponibilidade de amostras apresentado ao Comitê de Ética Espanhol, no qual se especifica o número de pacientes que já teriam a assinatura de Termo de Consentimento para Biobanco, bem como o número de pacientes falecidas e a solicitação da isenção de consentimento para ambas as situações. Anexamos também à respectiva aprovação do Comitê Ética Espanhol a este Termo de Biodisponibilidade. Anexado a Plataforma Brasil o TERMO DE BIODISPONIBILIDADE, PARECER FAVORÁVEL PARA TERMO DE BIODISPONIBILIDADE E PARECER FAVORAVEL AO PROJETO.

ANÁLISE: PENDÊNCIA ATENDIDA.

b) Na página 05 de 08 , item "5. Materiais e Métodos", lê-se: "Os dados clínicos serão recolhidos EM PRONTUÁRIOS FÍSICOS DOS TRÊS CENTROS PARTICIPANTES COM A COLABORAÇÃO DESTAS INSTITUIÇÕES E DOS PESQUISADORES ENVOLVIDOS. Tais revisões de prontuários e coletas de dados estão autorizadas pelos responsáveis cabiveis. As amostras histológicas passarão por estudo molecular e imunohistoquímico em cooperação entre os centros participantes e com a autorização dos responsáveis por estas." (Destaque nosso). Solicitam-se esclarecimentos e documento assinado e datado da aprovação pelos CEP no Brasil e fora do país, quanto à utilização de amostras histológicas.

RESPOSTA: A solicitação para utilização das amostras histológicas brasileiras é parte da presente solicitação e esperamos sua aprovação.

No caso das amostras espanholas anexamos previamente à permissão original e traduzida de uso das amostras histológicas por seu respectivo responsável e agora acrescentamos o Parecer

Endereço: SEPN 510 NORTE, BLOCO A $3^{\circ}$ ANDAR, Edifício Ex-INAN - Unidade II - Ministério da Saúde Bairro: Asa Norte

UF: DF Município: BRASILIA CEP: $70.750-521$

Telefone: (61)3315-5878

E-mail: conep@saude.gov.br 


\section{COMISSÃO NACIONAL DE ÉTICA EM PESQUISA}

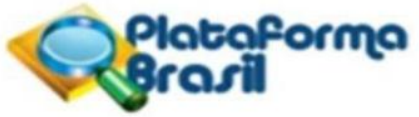

Continuação do Parecer: 1.440.107

Favorável ao Termo de Biodisponibilidade de amostras apresentado ao Comitê de Ética Espanhol. ANÁLISE: PENDÊNCIA ATENDIDA.

c) Na página 06 de 08, item "9. Riscos e Benefícios", lê-se: "Tendo em consideração o fato de que o projeto será realizado utilizando a revisão de prontuários e a realização de exames moleculares em blocos de parafina, consideramos o mesmo com potencial mínimo de riscos. A FIM DE MINIMIZAR ESTES RISCOS NOS CONCERNE À MANUTENÇÃO DO SIGILO E A NÃO EXPOSIÇÃO DOS PACIENTES. Resultados relevantes serão divulgados apenas em revistas cientificas sem que a identidade dos pacientes seja revelada." (Destaque nosso). Solicita-se incluir neste item informação de que os dados obtidos dos prontuários das participantes serão anonimizados/codificados antes de serem repassados a qualquer outra instância ética ou sanitária/profissional/instituição/empresa/órgão financiador. Apresentar também no projeto detalhado os procedimentos de anonimização/codificação que serão utilizados, de modo a garantir a confidencialidade, o sigilo e a privacidade das participantes (Resolução CNS n 466 de 2012, itens III.1.c, III.2.i e IV.3.e).

RESPOSTA: Detalhado no Item 9 página 9 Riscos e Benefícios no Projeto Versão 1.2 de 04.12.15. ANÁLISE: PENDÊNCIA ATENDIDA.

7 - Com relação à dispensa de TCLE, verifica-se a justificativa na Plataforma Brasil: "Solicitamos a dispensa do termo de consentimento por se tratar de estudo realizado em pacientes portadoras de neoplasia maligna de grande mortalidade, baseada em dados da literatura ( $50 \%$ das pacientes sofrerão óbito em decorrência desta neoplasia)." (Destaque nosso). Solicita-se esclarecer as dificuldades de contato com participantes/representante legal, via contato telefônico ou via correios, para autorização da utilização dos dados dos prontuários e das amostras armazenadas, principalmente das com perda de seguimento. Reiterase a necessidade da busca da autorização dos pacientes que ainda estiverem vivos, para uso de seus dados, pois é direito deles o exercício da AUTONOMIA.

RESPOSTA: Temos como objetivo manter a Autonomia do paciente no estudo em vigência e por isso serão realizados esforços para que se obtenha o termo de consentimento. Não obstante temos em mente a dificuldade logística de conseguir tais termos de consentimento via contato telefônico ou via correio, principalmente das pacientes com perda de seguimento, por trabalharmos com instituições de referência de regiões amplas exigindo custos e tempo para tais contatos. Além da possibilidade de que o transporte das pacientes para a assinatura do termo de

\footnotetext{
Endereço: SEPN 510 NORTE, BLOCO A $3^{\circ}$ ANDAR, Edifício Ex-INAN - Unidade II - Ministério da Saúde Bairro: Asa Norte CEP: $70.750-521$ 


\section{COMISSÃO NACIONAL DE ÉTICA EM PESQUISA}

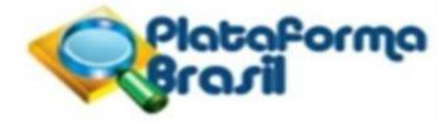

Continuação do Parecer: 1.440 .107

consentimento poderia trazer desconfortos e não as aportar benefícios diretos. Porém, o mais importante fato para impedimento desta obtenção de termo seria a alta mortalidade da enfermidade estudada. Segundo estimativa do SEER (http://seer.cancer.gov/statfacts/html/ovary.html9 - Acesso em 10/11/15) a sobrevida em 5 anos das pacientes diagnosticadas com câncer de ovário é de $45 \%$, por estudarmos um subtipo histológico com pior prognóstico entre os outros subtipos de câncer de ovário esperamos uma sobrevida ainda pior. Baseados em dados da literatura acreditamos que a maioria de nossas pacientes já tenha falecido no momento em que formos aptos a revisar suas histórias. Portanto solicitamos abstenção de TCLE para pacientes falecidas ao passo que para pacientes vivas estamos encaminhando o TCLE a ser assinado, para análise.

ANÁLISE: PENDÊNCIA ATENDIDA.

8 - Solicita-se que a pesquisadora responsável apresente declaração assinada e datada, garantindo que o material biológico e os dados obtidos na pesquisa serão utilizados exclusivamente para a finalidade prevista neste protocolo (Resolução CNS nº 466 de 2012, itens III.2.q e III.3.c).

RESPOSTA: Anexado a Plataforma Brasil DECLARAÇÃO DA PESQUISADORA.

ANÁLISE: PENDÊNCIA ATENDIDA.

9 - Quanto ao biorrepositório do estudo:

a) No Projeto Detalhado, Versão 1.1 de $12 / 06 / 2015$, documento intitulado "Projeto_versao_1_1_de_12_06_15.pdf", página 04 de 08, item "5. Materiais e Métodos": Solicita-se incluir neste item os detalhes dos procedimentos que serão realizados com o material biológico (blocos de parafina) das participantes, informando os equipamentos/máquinas/testes que serão utilizados, assim como as técnicas de processamento e o local de realização de cada etapa dos exames. Ademais, deve-se esclarecer neste item o local e o tempo de armazenamento, assim como a destinação final das amostras ao término do estudo. Ressalta-se que, dependendo do local de processamento e/ou armazenamento do material genético das participantes, o protocolo deverá ser enquadrado na área temática IX.4.1.1 e/ou IX.4.1.2 (Genética Humana) da Plataforma Brasil, conforme Resolução CNS n 466 de 2012. Neste caso, o projeto detalhado também deverá ser adequado conforme Resolução CNS n 340 de 2004, apresentando os mecanismos de proteção dos dados obtidos (itens III.1 e III.2), explicitação de acordo pré-existente quanto à propriedade das informações geradas (item IV.1.i), justificativa do envio do material biológico para outra

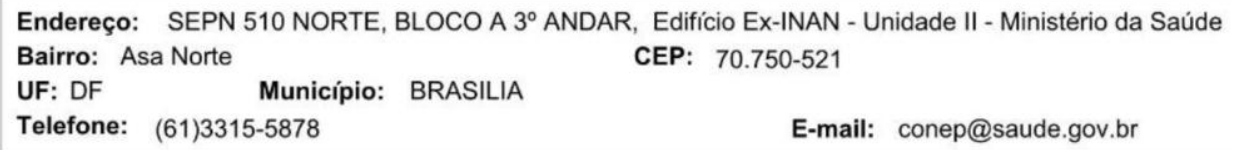




\section{COMISSÃO NACIONAL DE ÉTICA EM PESQUISA}

Continuação do Parecer: 1.440 .107

instituição, explicando a razão destes testes não poderem ser realizados no Brasil (item IV.1.k). RESPOSTA: Detalhado nas páginas 6-8, item 5 do Projeto versão 1.2 de 04.12 .15 os procedimentos a serem realizados com o material biológico das participantes do projeto, explicitando a participação de cada centro promotor.

ANÁLISE: PENDÊNCIA ATENDIDA.

b) Uma vez que haverá a constituição de biorrepositório de amostras biológicas neste estudo, conforme definição da Resolução CNS n 441 de 2011, Artigo $1^{\circ}$, item 1.II: "Biorrepositório: coleção de material biológico humano, coletado e armazenado ao longo da execução de um projeto de pesquisa específico, conforme regulamento ou normas técnicas, éticas e operacionais pré-definidas, sob responsabilidade institucional e sob gerenciamento do pesquisador, sem fins comerciais.", solicita-se esclarecer se haverá participação de mais de uma instituição na constituição do biorrepositório. Se sim, solicita-se apresentar acordo entre as instituições participantes contemplando operacionalização, compartilhamento, utilização do material biológico humano armazenado em Biorrepositório, inclusive a possibilidade de dissolução futura da parceria e a consequente partilha e destinação dos dados e materiais armazenados (Norma Operacional CNS nº 001 de 2013, Anexo II, Documentos necessários para armazenamento de material biológico humano em biorrepositório - atrelado a um projeto de pesquisa especifico).

RESPOSTA: Segue anexo na Plataforma Brasil ACORDO BIORREPOSITÓRIO.

ANÁLISE: PENDÊNCIA ATENDIDA.

c) Solicita-se esclarecer se haverá constituição ou participação de biorrepositório no exterior. Se sim, solicita -se apresentar documento garantindo à pesquisadora e às instituições brasileiras o direito ao acesso e utilização do material biológico humano armazenado no exterior (e não apenas das amostras depositadas pela pesquisadora). Deverá ser garantida, no mínimo, a proporcionalidade na participação e deverá ser apresentado o compromisso da instituição destinatária no exterior quanto à vedação do patenteamento e da utilização comercial de material biológico humano, em atenção à normativa brasileira, em especial, ao item 14 da Resolução CNS n 441 de 2011 e à Portaria MS n² 2.201 de 2011, capıtulo IV, seção I, artigos 11 e 12 (Norma Operacional CNS nº 001 de 2013, Anexo II, Documentos necessários para armazenamento de material biológico humano em biorrepositório - atrelado a um projeto de pesquisa específico).

RESPOSTA: Anexado a Plataforma Brasil TERMO DE RESPONSABILIDADE ESTRANGEIRA BIORREPOSITÓRIO.

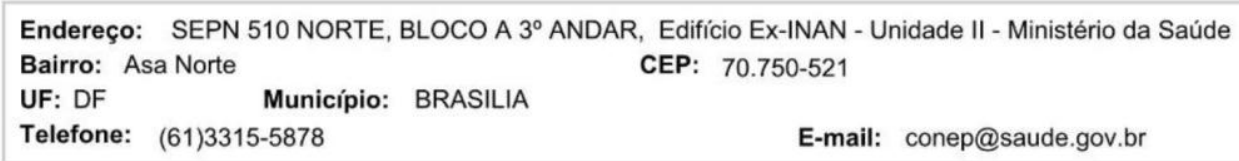




\section{COMISSÃO NACIONAL DE ÉTICA EM PESQUISA}

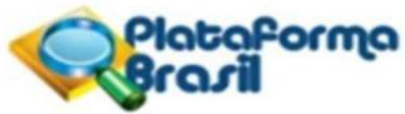

Continuação do Parecer: 1.440 .107

\section{ANÁLISE: PENDÊNCIA ATENDIDA.}

\section{Considerações Finais a critério da CONEP:}

Diante do exposto, a Comissão Nacional de Ética em Pesquisa - Conep, de acordo com as atribuições definidas na Resolução CNS n 466 de 2012 e na Norma Operacional nº 001 de 2013 do CNS, manifesta-se pela aprovação do projeto de pesquisa proposto.

Situação: Protocolo aprovado.

Este parecer foi elaborado baseado nos documentos abaixo relacionados:

\begin{tabular}{|c|c|c|c|c|}
\hline Tipo Documento & Arquivo & Postagem & Autor & Situação \\
\hline $\begin{array}{l}\text { Informações Básicas } \\
\text { do Proieto }\end{array}$ & $\begin{array}{l}\text { PB_INFORMAÇŌES_BÁSICAS_DO_P } \\
\text { ROJETO 458755.pdf }\end{array}$ & $\begin{array}{c}21 / 01 / 2016 \\
09: 39: 48\end{array}$ & & Aceito \\
\hline Outros & Carta_resposta_CONEP_2.doc & $\begin{array}{c}21 / 01 / 2016 \\
09: 31: 27\end{array}$ & $\begin{array}{l}\text { Mariana de Paiva } \\
\text { Batista }\end{array}$ & Aceito \\
\hline Outros & Carta_resposta_CONEP_2.pdf & $\begin{array}{c}21 / 01 / 2016 \\
09: 31: 05\end{array}$ & $\begin{array}{l}\text { Mariana de Paiva } \\
\text { Batista }\end{array}$ & Aceito \\
\hline $\begin{array}{l}\text { Projeto Detalhado / } \\
\text { Brochura } \\
\text { Investigador }\end{array}$ & Projeto_versao_1_2_de_04_12_15.docx & $\begin{array}{c}21 / 01 / 2016 \\
09: 30: 37\end{array}$ & $\begin{array}{l}\text { Mariana de Paiva } \\
\text { Batista }\end{array}$ & Aceito \\
\hline Folha de Rosto & Folha_de_rosto_3.pdf & $\begin{array}{c}21 / 01 / 2016 \\
09: 22: 30\end{array}$ & $\begin{array}{l}\text { Mariana de Paiva } \\
\text { Batista }\end{array}$ & Aceito \\
\hline Outros & $\begin{array}{l}\text { Termo_de_Responsabilidade_Estrangeir } \\
\text { a Biorepositorio TRADUCAO.docx }\end{array}$ & $\begin{array}{c}08 / 12 / 2015 \\
15: 34: 54\end{array}$ & $\begin{array}{l}\text { Mariana de Paiva } \\
\text { Batista }\end{array}$ & Aceito \\
\hline Outros & $\begin{array}{l}\text { Termo_de_Responsabilidade_Estrangeir } \\
\text { a Biorrepositorio.pdf }\end{array}$ & $\begin{array}{c}08 / 12 / 2015 \\
15: 34: 07\end{array}$ & $\begin{array}{l}\text { Mariana de Paiva } \\
\text { Batista }\end{array}$ & Aceito \\
\hline Outros & Acordo_Biorrepositorio_AC.docx & $\begin{array}{c}08 / 12 / 2015 \\
15: 33: 22\end{array}$ & $\begin{array}{l}\text { Mariana de Paiva } \\
\text { Batista }\end{array}$ & Aceito \\
\hline Outros & Acordo_Biorrepositorio_AC.pdf & $\begin{array}{c}08 / 12 / 2015 \\
14: 49: 07\end{array}$ & $\begin{array}{l}\text { Mariana de Paiva } \\
\text { Batista }\end{array}$ & Aceito \\
\hline Outros & Acordo_Biorrepositorio_IVO.docx & $\begin{array}{c}08 / 12 / 2015 \\
14: 48: 28\end{array}$ & $\begin{array}{l}\text { Mariana de Paiva } \\
\text { Batista }\end{array}$ & Aceito \\
\hline Outros & Acordo_Biorrepositorio_IVO.pdf & $\begin{array}{c}08 / 12 / 2015 \\
14: 47: 52\end{array}$ & $\begin{array}{l}\text { Mariana de Paiva } \\
\text { Batista }\end{array}$ & Aceito \\
\hline Outros & Acordo_Biorrepositorio_HC.docx & $\begin{array}{c}08 / 12 / 2015 \\
14: 47: 23\end{array}$ & $\begin{array}{l}\text { Mariana de Paiva } \\
\text { Batista }\end{array}$ & Aceito \\
\hline Outros & Acordo_Biorrepositorio_HC.pdf & $\begin{array}{c}08 / 12 / 2015 \\
14: 46: 59\end{array}$ & $\begin{array}{l}\text { Mariana de Paiva } \\
\text { Batista }\end{array}$ & Aceito \\
\hline Outros & Declaracao_da_pesquisadora.docx & $\begin{array}{c}08 / 12 / 2015 \\
14: 46: 06\end{array}$ & $\begin{array}{l}\text { Mariana de Paiva } \\
\text { Batista }\end{array}$ & Aceito \\
\hline
\end{tabular}

Endereço: SEPN 510 NORTE, BLOCO A $3^{\circ}$ ANDAR, Edifício Ex-INAN - Unidade II - Ministério da Saúde Bairro: Asa Norte

UF: DF Município: BRASILIA CEP: $70.750-521$ 


\section{COMISSÃO NACIONAL DE ÉTICA EM PESQUISA}

\section{aposerame (a)}

Continuação do Parecer: 1.440 .107

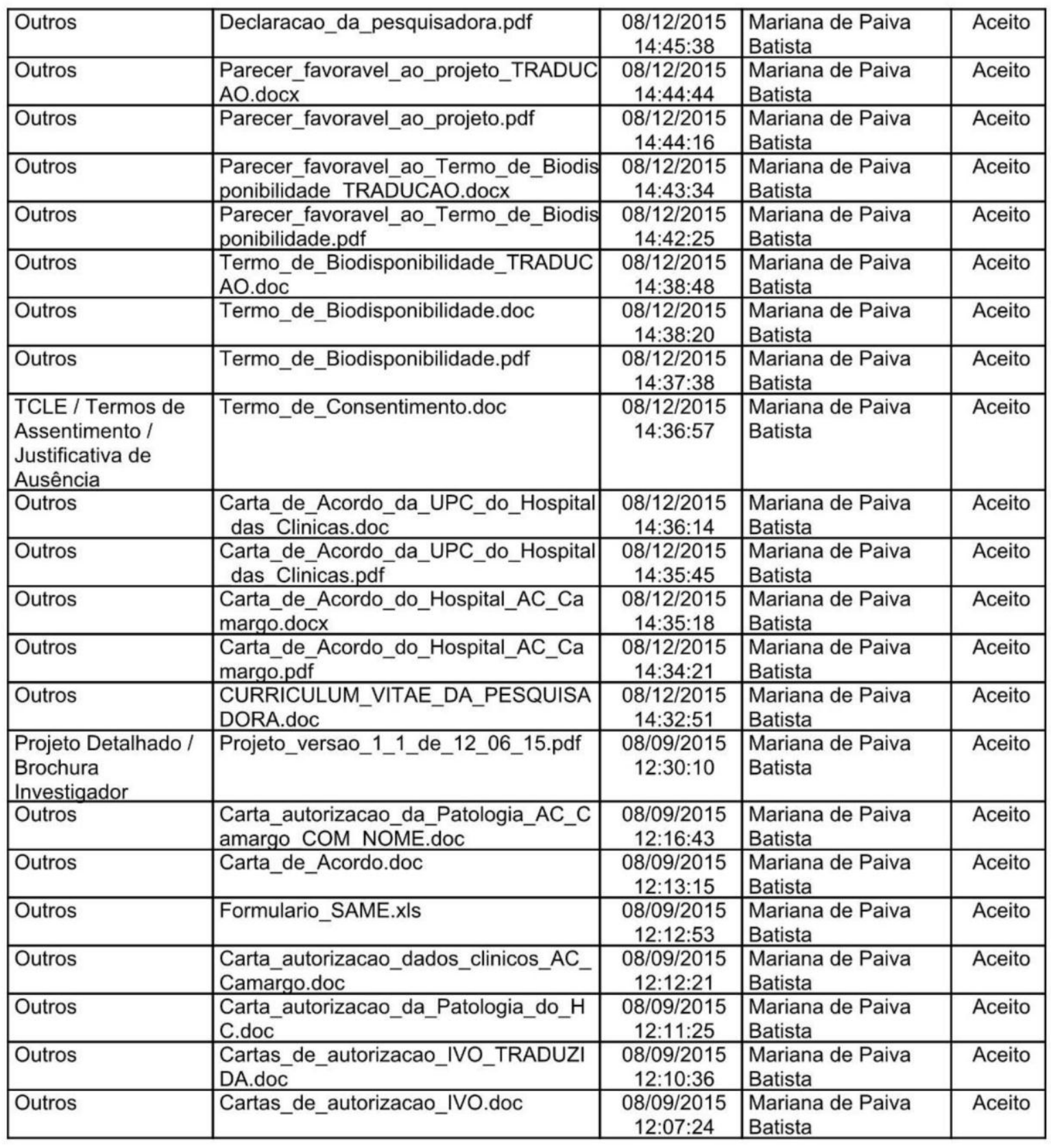

Endereço: SEPN 510 NORTE, BLOCO A $3^{\circ}$ ANDAR, Edifício Ex-INAN - Unidade II - Ministério da Saúde

Bairro: Asa Norte

UF: DF

CEP: $70.750-521$

Telefone: (61)3315-5878

E-mail: conep@saude.gov.br 


\section{COMISSÃO NACIONAL DE ÉTICA EM PESQUISA}

Continuação do Parecer: 1.440 .107

\begin{tabular}{|l|l|c|l|l|}
\hline Outros & Carta_resposta.doc & $08 / 09 / 2015$ & $\begin{array}{l}\text { Mariana de Paiva } \\
\text { Batista }\end{array}$ & Aceito \\
\hline
\end{tabular}

\section{Situação do Parecer:}

Aprovado

Necessita Apreciação da CONEP:

Sim

BRASILIA, 08 de Março de 2016

Assinado por:

Jorge Alves de Almeida Venancio

(Coordenador)

Endereço: SEPN 510 NORTE, BLOCO A $3^{\circ}$ ANDAR, Edifício Ex-INAN - Unidade II - Ministério da Saúde

Bairro: Asa Norte

UF: DF Município: BRASILIA

Telefone: (61)3315-5878

CEP: $70.750-521$

E-mail: conep@saude.gov.br 


\section{COMISSÃO NACIONAL DE ÉTICA EM PESQUISA}

\section{PARECER CONSUBSTANCIADO DA CONEP}

\section{DADOS DA EMENDA}

Título da Pesquisa: Projeto de estudo: Perfil Molecular do Carcinoma de células Claras de Ovário e sua correlação clínica na experiência de três instituições.

Pesquisador: Mariana de Paiva Batista

Área Temática: Pesquisas com coordenação e/ou patrocínio originados fora do Brasil, excetuadas aquelas com copatrocínio do Governo Brasileiro;

Versão: 6

CAAE: 42441915.3 .0000 .5440

Instituição Proponente: Hospital das Clínicas da Faculdade de Medicina de Ribeirão Preto da USP -

Patrocinador Principal: FUNDACAO DE AMPARO A PESQUISA DO ESTADO DE SAO PAULO

\section{DADOS DO PARECER}

\section{Número do Parecer: 2.630 .745}

Apresentação do Projeto:

As informações elencadas nos campos "Apresentação do Projeto", "Objetivo da Pesquisa" e "Avaliação dos Riscos e Benefícios" foram retiradas do arquivo "Informações Básicas da Pesquisa" ("PB_INFORMAÇÕES_BÁSICAS_1068417_E1.pdf", de 30/01/2018).

\section{INTRODUÇÃO}

O Carcinoma de ovário compreende um grupo de neoplasias heterogêneo de elevada incidência, morbidade e mortalidade em todo o mundo (1). Sua incidência atinge cerca de 13.5/100 000 pacientes por ano em países desenvolvidos (2).

Histologicamente, o tipo epitelial é o mais comum (>95\%) seguido dos tipos estromal e germinativo. O tipo epitelial é subclassificado, em ordem de prevalência, em seroso, endometrióide, células claras e mucinoso. O tratamento considerado padrão consiste na ressecção cirúrgica ótima para todos os casos, independente do tipo histológico, seguido de quimioterapia adjuvante baseada em platina em estadios iniciais com alto risco de recaída (IA e IB sendo G3 ou células claras, IC e II) como para estadios avançados (III e IV) NCCN.

Apesar do tratamento padrão, um número considerável de pacientes apresentará recorrência de doença e aproximadamente $50 \%$ terão óbito relacionado a ela (3). Comumente a disseminação

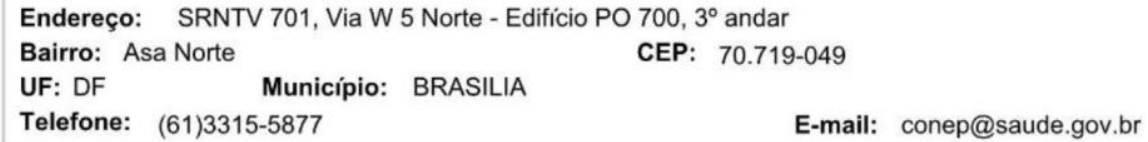




\section{COMISSÃO NACIONAL DE ÉTICA EM PESQUISA}

Continuação do Parecer: 2.630 .745

ocorre na cavidade abdominal para o peritôneo e via linfática. A disseminação hematogênica é incomum, preferencialmente para fígado e pulmões e raramente para ossos. O Carcinoma de Células Claras é considerado uma entidade única dentre os demais subtipos, em decorrência de suas características clínicas e patofisiológicas peculiares.

Estes dados motivam a realização de pesquisas que subsidiem a caracterização do comportamento biológico desta neoplasia e a identificação de possiveis alvos para novas linhas de tratamento.

Neste context o carcinoma epitelial de ovário é dividido em dois grupos, de acordo com Kurman and Shih, baseado em características morfológicas, genéticas e imunohistoquímicas.

Tipo I: tumores de células claras, tumores de baixo grau dos tipos endometrióide, mucinoso, seroso e carcinoma transicional. Comumente se desenvolvem de lesões precursoras e de forma lenta. Mutações comuns em diferentes genes são partilhadas e podem ser identificadas: KRAS, BRAF, PTEN, PIK3CA, ARID1A, ERBB2, CTNNB1 e PPP2R1A.

Tipo II: carcinoma seroso de alto grau, carcinoma indiferenciado e tumores mesodérmicos malignos mistos (carcinosarcoma). Comumente se originam do epitélio distal das tubas uterinas e apresentam comportamento agressivo. Mutações em TP53 são identificadas em $80 \%$ destes casos, assim como o são altos niveis de instabilidade genética. (2-5)

O Carcinoma de Células Claras é considerado uma entidade única dentre os demais subtipos, em decorrência de suas características clínicas e patofisiológicas peculiares (6-8):

a. Sua incidência global varia entre 5 e 25\%. Na Europa e América do Norte está em torno 1-12\%, enquanto no Japão alcança $15-25 \%$. (9), fato

que sugere predisposição da população japonesa a este tipo de tumor.

b. Costuma afetar mulheres mais jovens que as afetadas pelo tipo seroso mais comum [média de idade ao diagnóstico 55 vs 64 anos] (10) e a maioria são diagnosticadas em estadios iniciais (I / II) [47-95\%] (11)

c. Frequentemente se apresenta como massa pélvica de grande volume, raramente bilateral.

d. Apresentam pobre resposta a quimioterapia convencional baseada em platina, embora novos estudos vêm demonstrado sobrevida global e sobrevida livre de progressão semelhantes ao tipo seroso, quando diagnosticado em estádios iniciais.

e. Incidência elevada de eventos tromboembólicos (>40\% dos casos) (12) e associação com endometriose. $(13,14)$

f. Ocorrência de Hipercalcemia é mais frequentemente observada.

A respeito do envolvimento ósseo, estudos demonstram que a ocorrência de metástases ósseas em carcinomas de ovário epiteliais é rara, 0.1- 0.12\% conforme repostado em algumas séries de

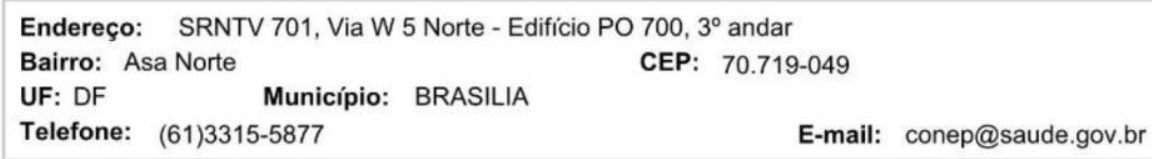




\section{COMISSÃO NACIONAL DE ÉTICA EM PESQUISA}

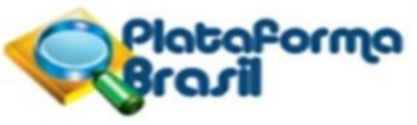

Continuação do Parecer: 2.630 .745

casos (23). Todavia, estudo asiático reportou 103 casos de carcinoma de ovário aonde se apresentou envolvimento ósseo em 4 casos, nenhum deles provindos de CCC. Estes casos culminaram em baixas taxas de sobrevida global (8 meses) (21)). Zhang et al relataram 26 casos de metastases ósseas de carcinoma de ovário, com uma incidência de $0.82 \%$ com envolvimento mais frequente de pelve e vértebras (22). Estudo alemão, relatou incidência de metástases ósseas em carcinoma de ovário em $1.5 \%$ dos casos. Correlacionou ainda o intervalo de tempo entre o desenvolvimento destas metástases e o diagnóstico do câncer com o prognóstico. Caso ocorra em intervalo menor que 12 meses apresenta media de sobrevida global entre 11.2 meses, caso ocorra em intervalo > 12 meses a sobrevida global alcança 78.4 meses(23). A biologia molecular e genômica do CCC, não completamente elucidada, ainda permanence menos compreendida que a biologia dos outros tumores epiteliais de ovário de alto grau. Carcinomas de células claras frequentemente apresentam:

Imunohistoquímica negativa em: receptores de estrógeno (ER), tumor Wilms 1 (WT1) e proteína 53 (p53) caracterizando - o 'triplo negativo' (6) - com uma baixa frequência de mutações BRCA 1 e 2 (13.2\% - câncer de ovário invasivo).

Baixos niveis de instabilidade cromossômica e baixas taxas de proliferação cellular, com alta frequência de mutações da phosphoinositide 3- kinase catalytic alpha (PIK3CA mutações) estimadas em 40\%. (5)

Mutações truncadas e perda da expressão proteica do gene de supressão tumoral ARID1A, o qual é responsabilizado pela patologia envolvida entre endometriose contígua atípica e CCC, como evidenciado por Wiegand et al (12),. Mutações em PP2R1A (7.1\%) e KRAS (4.7\%), como demonstrado pelo sequenciamento desenvolvido por Sanger em 42 casos confirmados de CCC (o qual também identificou mutações de ARID1A em $57 \%$ dos casos).

Alta expressão celular de ALDH1. ALDH1 é um marcador de células tronco like e células inicializadoras, em carcinoma de ovário (CCC e adenocarcinoma seroso). O seu nivel de expressão pode ser um novo biomarcador para predição de mau prognóstico, como descrito por Kuroda et al.

\section{HIPÓTESE}

- O comportamento clínico distinto do CCC pode ser observado em outras populações de pacientes.

- O perfil molecular descrito no CCC também está presente em populações distintas.

- O perfil molecular se correlaciona com o comportamento clínico distinto do CCC.

Endereço: SRNTV 701, Via W 5 Norte - Edifício PO 700, $3^{\circ}$ andar

Bairro: Asa Norte CEP: $70.719-049$

UF: DF Município: BRASILIA

Telefone: (61)3315-5877

E-mail: conep@saude.gov.br 


\section{COMISSÃO NACIONAL DE ÉTICA EM PESQUISA}

Continuação do Parecer: 2.630 .745

\section{METODOLOGIA}

Revisando os prontuários médicos provindos de quatro conhecidos centros de tratamento e pesquisa em oncologia, um deles na Espanha (Área Clínica de Oncologia Ginecologica of the Instituto Valenciano de Oncologia), outros dois no Brasil (Divisão de Oncologia Ginecológica do Hospital das Clínicas da Faculdade de Medicina de Ribeirão Preto da Universidade de São Paulo e Divisão de Oncologia Ginecológica do Hospital AC Camargo) e um na Costa Rica (Hospital Mexico), buscamos identificar casos de Carcinoma de Ovário do tipo histológico Células Claras, tamanho amostral de 60 casos, e identificá-los segundo as seguintes características clínicas:

- idade e estadiamento ao diagnóstico

- etnia (asiática ou não asiática)

- história de endometriose

- ocorrência de eventos tromboembólicos

- ocorrência de metástases ósseas

- Sobrevida Livre de Progressão (avaliando a resistência a platina e taxano como esquema adjuvante ou de primeira linha paliativa); definiremos resistência como ocorrência de progressão de doença durante a quimioterapia ou nos primeiros 6 meses após fim do tratamento quimioterápico. (8)

- Sobrevida Global

As amostras histológicas passarão por estudo molecular e imunohistoquímico para a definição das seguintes características moleculares:

2a.) Imunohistoquímicas:

- Expressão de HNF1B; WT1; ER; PR; p53;

- Expressão de MLH1, MSH2, MSH6, PMS2 e ALDH1.

2b.) Análise genética:

- mutações de ARID1A; PIK3CA e MSI

- variação no número de cópias de CDKN2A/B, ZNF217

A análise destas características e sua correlação com o perfil genético dariam suporte à hipótese de provável relação entre elas.

Será solicitada junto aos comitês de ética das instituições envolvidas a liberação do termo de consentimento, por se tratar de estudo realizado em pacientes em sua maioria já falecidas ou com perda de seguimento.

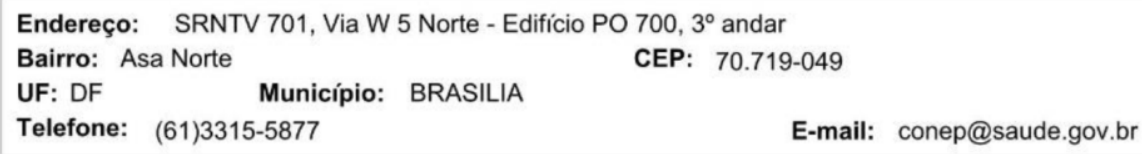




\section{COMISSÃO NACIONAL DE ÉTICA EM PESQUISA}

\section{Q platoformo}

Continuação do Parecer: 2.630 .745

\section{CRITÉRIOS DE INCLUSÃO}

Após busca de casos de carcinoma de ovário de células claras nos centros de oncologia descritos, estimamos um tamanho amostral de cerca de 40 casos. Incluiremos em nosso projeto o estudo clínico e molecular de amostras de tumores cujos exames anatomo-patológicos revelem tumores deste subtipo histológico. Serão incluídas pacientes femininas e maiores de 18 anos.

\section{CRITÉRIOS DE EXCLUSÃO}

Serão excluídos os demais subtipos histológicos de carcinoma de ovário.

\section{Objetivo da Pesquisa:}

\section{OBJETIVOS PRIMÁRIOS}

- Respaldados pelas evidências apresentadas, pretendemos:

- Definir as características clínicas predominantes dos pacientes portadores de CCC em uma população ampla e as comparar com dados da literatura atual.

- Identificar nesta população a ocorrência do distinto perfil molecular do CCC já descrito.

- Avaliar a correspondência entre o perfil molecular e o comportamento clínico distinto observado nos CCC, especialmente a ocorrência de metástases ósseas, eventos tromboembólicos e taxas de resposta a primeira linha de quimioterapia baseada em platina e taxano.

\section{Avaliação dos Riscos e Benefícios:}

RIScos

Tendo em consideração o fato de que o projeto será realizado utilizando a revisão de prontuários e a realização de exames moleculares em blocos de parafina, consideramos o mesmo com potencial mínimo de riscos. A fim de minimizar estes riscos nos concerne à manutenção do sigilo e a não exposição dos pacientes. Resultados relevantes serão divulgados apenas em revistas cientificas sem que a identidade dos pacientes seja revelada.

\section{BENEFICIOS}

Esperamos acrescentar conhecimentos à cerca da fisiopatologia do carcinoma de ovário de células claras, levando a um melhor entendimento da relação entre seu perfil molecular e seu comportamento clínico, evidenciando perfis moleculares correlacionados com a evolução para metástases ósseas. Nosso estudo poderia contribuir para a pesquisa de potenciais alvos moleculares especificos para este subtipo histológico.

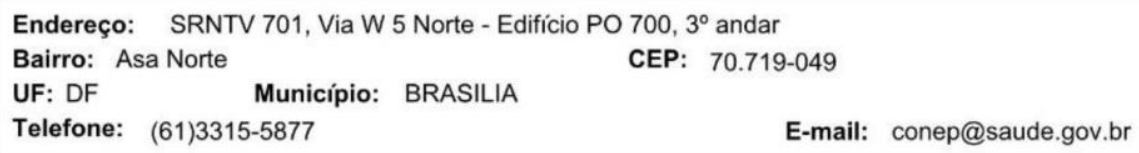




\section{COMISSÃO NACIONAL DE ÉTICA EM PESQUISA}

Continuação do Parecer: 2.630 .745

\section{Comentários e Considerações sobre a Pesquisa:}

\section{EMENDA 01}

Trata-se de análise da emenda 1 ao estudo principal, aprovado pela Conep em 09/11/2015, sob o parecer $n^{\circ}$ 1.308.356.

A emenda propõe a atualização do PROJETO DETALHADO - versão 1.3 de 08/12/2017 referente ao arquivo "Projeto_versao_1_3_de_08_12_17_com_alteracoes_destacadas.pdf" postado na Plataforma Brasil em $30 / 01 / 2018$.

A razão principal para as alterações é a Inclusão de Coparticipante estrangeiro (México - Costa Rica) para aumento do $\mathrm{N}$ amostral. Segundo a pesquisadora, uma vez que se refere à patologia rara torna-se necessária a colaboração de vários centros para que se obtenha uma amostra significativa. Ressalta-se que o projeto está sendo desenvolvido em caráter de pós-graduação vinculado ao programa de Oncologia Clínica da USP.

1. INCLUSÃO DE CENTRO Coparticipante:

Instituição: Hospital México - San José/Costa Rica.

Pesquisador Responsável: Dr. Juan Pablo Molina.

\section{Considerações sobre os Termos de apresentação obrigatória:}

Ver item "Conclusões ou Pendências e Lista de Inadequações".

\section{Recomendações:}

Ver item "Conclusões ou Pendências e Lista de Inadequações".

Conclusões ou Pendências e Lista de Inadequações:

RESPOSTA AO PARECER CONSUBSTANCIADO CONEP № 2.522.757:

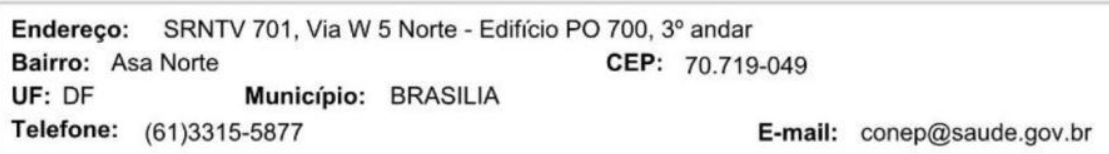




\section{COMISSÃO NACIONAL DE ÉTICA EM PESQUISA}

Continuação do Parecer: 2.630 .745

1. Quanto ao Projeto Detalhado, arquivo intitulado "Projeto_versao_1_3_de_08_12_17_com_alteracoes_destacadas.pdf", postado em 30/01/2018, na página 1, de 9, lê-se:"Materiais e métodos: A fim de fornecer dados que possam beneficiar futuros pacientes, realizaremos a revisão de prontuários e a análise molecular de amostras de carcinoma de ovário de células claras diagnosticados EM 3 CONHECIDOS centros de oncologia - Instituto Valenciano de Oncologia Espanha, Hospital das Clínicas da Faculdade de Medicina de Ribeirão Preto, Hospital AC Camargo e Hospital México - Costa Rica." (Destaque nosso). Tendo em vista que a referida emenda solicita a inclusão de centro estrangeiro, solicita-se correção do trecho destacado atualizando a quantidade de centros participantes neste projeto.

RESPOSTA: Alterado na página 4 (item 5) do projeto versão 1.4 de 19.03.18.

ANÁLISE: PENDÊNCIA ATENDIDA.

2. Quanto ao Acordo para Constituição de Biorrepositório em Comum, arquivo intitulado "Acordo_Biorrepositorio_CR_port.doc" postado em 30/01/2018, lê-se: "Todo o material biológico humano reunido fará parte de um Biorrepositório em comum entre OS TRÊS CENTROS participantes que será mantido durante a realização do projeto". (Destaque nosso) Considerando que a referida emenda solicita a inclusão de centro estrangeiro, solicita-se a adequação do documento submetido para apreciação. Ressaltase que a nova versão do documento deverá estar devidamente assinada pelo pesquisador responsável pelo Biorrepositório no exterior.

RESPOSTA: Corrigido documento e anexado a Plataforma com o seguinte Título: Acordo_Birroepositorio_CR_port2.doc. A respectiva carta assinada pelo pesquisador responsável pelo Biorrepositório no exterior também foi anexada com o título: Collaborative_center_CR_2. ANÁLISE: PENDÊNCIA ATENDIDA.

\section{Considerações Finais a critério da CONEP:}

Diante do exposto, a Comissão Nacional de Ética em Pesquisa - Conep, de acordo com as atribuições definidas na Resolução CNS n 466 de 2012 e na Norma Operacional nº 001 de 2013 do CNS, manifesta-se pela aprovação da emenda proposta ao projeto de pesquisa.

Situação: Emenda aprovada.

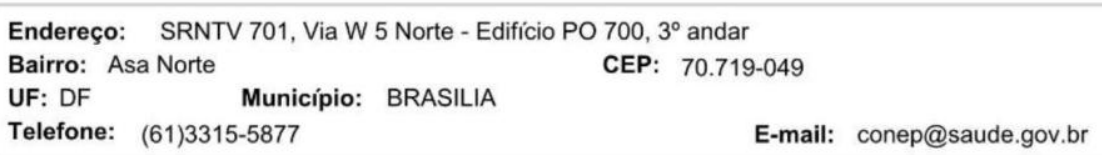




\section{COMISSÃO NACIONAL DE ÉTICA EM PESQUISA}

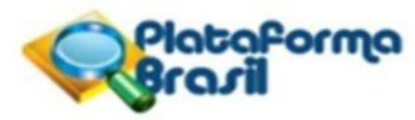

Continuação do Parecer: 2.630 .745

Este parecer foi elaborado baseado nos documentos abaixo relacionados:

\begin{tabular}{|c|c|c|c|c|}
\hline Tipo Documento & Arquivo & Postagem & Autor & Situação \\
\hline $\begin{array}{l}\text { Informações Básicas } \\
\text { do Projeto }\end{array}$ & $\begin{array}{l}\text { PB_INFORMAÇŌES_BÁSICAS_106841 } \\
7 \text { E1.pdf }\end{array}$ & $\begin{array}{c}21 / 03 / 2018 \\
15: 28: 27\end{array}$ & & Aceito \\
\hline $\begin{array}{l}\text { Projeto Detalhado / } \\
\text { Brochura } \\
\text { Investigador }\end{array}$ & $\begin{array}{l}\text { Projeto_versao_1_4_de_19_03_18_com } \\
\text {-alteracoes_destacadas_2.pdf }\end{array}$ & $\begin{array}{c}21 / 03 / 2018 \\
15: 27: 26\end{array}$ & $\begin{array}{l}\text { Mariana de Paiva } \\
\text { Batista }\end{array}$ & Aceito \\
\hline Outros & Collaborative_center_CR_2.pdf & $\begin{array}{c}21 / 03 / 2018 \\
15: 22: 55\end{array}$ & $\begin{array}{l}\text { Mariana de Paiva } \\
\text { Batista }\end{array}$ & Aceito \\
\hline Outros & Carta_resposta.pdf & $\begin{array}{c}21 / 03 / 2018 \\
15: 22: 08\end{array}$ & $\begin{array}{l}\text { Mariana de Paiva } \\
\text { Batista }\end{array}$ & Aceito \\
\hline Outros & Acordo_Biorrepositorio_CR_port_2.doc & $\begin{array}{c}21 / 03 / 2018 \\
15: 21: 28\end{array}$ & $\begin{array}{l}\text { Mariana de Paiva } \\
\text { Batista }\end{array}$ & Aceito \\
\hline Outros & $\begin{array}{l}\text { Termo_de_responsabilidade_CR_port.d } \\
\text { oc }\end{array}$ & $\begin{array}{c}30 / 01 / 2018 \\
11: 18: 13\end{array}$ & $\begin{array}{l}\text { Mariana de Paiva } \\
\text { Batista }\end{array}$ & Aceito \\
\hline Outros & Relatorio_Andamento_do_Projeto.pdf & $\begin{array}{c}30 / 01 / 2018 \\
11: 17: 40\end{array}$ & $\begin{array}{l}\text { Mariana de Paiva } \\
\text { Batista }\end{array}$ & Aceito \\
\hline $\begin{array}{l}\text { Projeto Detalhado / } \\
\text { Brochura } \\
\text { Investigador }\end{array}$ & $\begin{array}{l}\text { Projeto_versao_1_3_de_08_12_17_com } \\
\text {-alteracoes_destacadas.pdf }\end{array}$ & $\begin{array}{c}30 / 01 / 2018 \\
11: 16: 56\end{array}$ & $\begin{array}{l}\text { Mariana de Paiva } \\
\text { Batista }\end{array}$ & Aceito \\
\hline Outros & Pathology_HMexico.pdf & $\begin{array}{l}30 / 01 / 2018 \\
11: 15: 28\end{array}$ & $\begin{array}{l}\text { Mariana de Paiva } \\
\text { Batista }\end{array}$ & Aceito \\
\hline Outros & Pathology.doc & $\begin{array}{c}30 / 01 / 2018 \\
11: 14: 58\end{array}$ & $\begin{array}{l}\text { Mariana de Paiva } \\
\text { Batista }\end{array}$ & Aceito \\
\hline Outros & Dados_clinicos_CR_port.doc & $\begin{array}{c}30 / 01 / 2018 \\
11: 14: 29\end{array}$ & $\begin{array}{l}\text { Mariana de Paiva } \\
\text { Batista }\end{array}$ & Aceito \\
\hline Outros & Commitment_with_the_Biobank.docx & $\begin{array}{c}30 / 01 / 2018 \\
11: 14: 00\end{array}$ & $\begin{array}{l}\text { Mariana de Paiva } \\
\text { Batista }\end{array}$ & Aceito \\
\hline Outros & Commitment_letter.docx & $\begin{array}{c}30 / 01 / 2018 \\
11: 13: 29 \\
\end{array}$ & $\begin{array}{l}\text { Mariana de Paiva } \\
\text { Batista }\end{array}$ & Aceito \\
\hline Outros & Collaborative_center_CR.pdf & $\begin{array}{c}30 / 01 / 2018 \\
11: 12: 56\end{array}$ & $\begin{array}{l}\text { Mariana de Paiva } \\
\text { Batista }\end{array}$ & Aceito \\
\hline Outros & ClinicalData_HMexico.pdf & $\begin{array}{c}30 / 01 / 2018 \\
11: 12: 21 \\
\end{array}$ & $\begin{array}{l}\text { Mariana de Paiva } \\
\text { Batista }\end{array}$ & Aceito \\
\hline Outros & Clinical_Data.doc & $\begin{array}{c}30 / 01 / 2018 \\
11: 10: 52 \\
\end{array}$ & $\begin{array}{l}\text { Mariana de Paiva } \\
\text { Batista }\end{array}$ & Aceito \\
\hline Outros & Carta_patologia_CR_port.docx & $\begin{array}{c}30 / 01 / 2018 \\
11: 10: 23\end{array}$ & $\begin{array}{l}\text { Mariana de Paiva } \\
\text { Batista }\end{array}$ & Aceito \\
\hline Outros & Carta_para_emenda_do_projeto.pdf & $\begin{array}{c}30 / 01 / 2018 \\
11: 09: 50\end{array}$ & $\begin{array}{l}\text { Mariana de Paiva } \\
\text { Batista }\end{array}$ & Aceito \\
\hline Outros & Biobank_CR.pdf & $\begin{array}{c}30 / 01 / 2018 \\
11: 09: 15\end{array}$ & $\begin{array}{l}\text { Mariana de Paiva } \\
\text { Batista }\end{array}$ & Aceito \\
\hline Outros & Acordo_Biorrepositorio_CR_port.doc & $\begin{array}{c}30 / 01 / 2018 \\
11: 08: 01 \\
\end{array}$ & $\begin{array}{l}\text { Mariana de Paiva } \\
\text { Batista } \\
\end{array}$ & Aceito \\
\hline Outros & Carta_resposta_CONEP_2.doc & $\begin{array}{c}21 / 01 / 2016 \\
09: 31: 27\end{array}$ & $\begin{array}{l}\text { Mariana de Paiva } \\
\text { Batista }\end{array}$ & Aceito \\
\hline
\end{tabular}

Endereço: SRNTV 701, Via W 5 Norte - Edifício PO 700, $3^{\circ}$ andar

Bairro: Asa Norte

UF: DF

CEP: $70.719-049$

Telefone: (61)3315-5877

E-mail: conep@saude.gov.br 


\section{COMISSÃO NACIONAL DE ÉTICA EM PESQUISA}

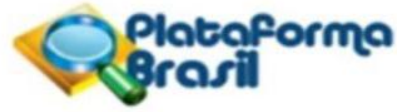

Continuação do Parecer: 2.630 .745

\begin{tabular}{|c|c|c|c|c|}
\hline Outros & Carta_resposta_CONEP_2.pdf & $\begin{array}{l}21 / 01 / 2016 \\
09: 31: 05\end{array}$ & $\begin{array}{l}\text { Mariana de Paiva } \\
\text { Batista }\end{array}$ & Aceito \\
\hline $\begin{array}{l}\text { Projeto Detalhado / } \\
\text { Brochura } \\
\text { Investigador }\end{array}$ & Projeto_versao_1_2_de_04_12_15.docx & $\begin{array}{l}21 / 01 / 2016 \\
09: 30: 37\end{array}$ & $\begin{array}{l}\text { Mariana de Paiva } \\
\text { Batista }\end{array}$ & Aceito \\
\hline Folha de Rosto & Folha_de_rosto_3.pdf & $\begin{array}{l}21 / 01 / 2016 \\
09: 22: 30\end{array}$ & $\begin{array}{l}\text { Mariana de Paiva } \\
\text { Batista }\end{array}$ & Aceito \\
\hline Outros & \begin{tabular}{|l|} 
Termo_de_Responsabilidade_Estrangeir \\
a Biorepositorio TRADUCAO.docx
\end{tabular} & $\begin{array}{c}08 / 12 / 2015 \\
15: 34: 54\end{array}$ & $\begin{array}{l}\text { Mariana de Paiva } \\
\text { Batista }\end{array}$ & Aceito \\
\hline Outros & $\begin{array}{l}\text { Termo_de_Responsabilidade_Estrangeir } \\
\text { a Biorrepositorio.pdf }\end{array}$ & $\begin{array}{l}08 / 12 / 2015 \\
15: 34: 07\end{array}$ & $\begin{array}{l}\text { Mariana de Paiva } \\
\text { Batista }\end{array}$ & Aceito \\
\hline Outros & Acordo_Biorrepositorio_AC.docx & $\begin{array}{l}08 / 12 / 2015 \\
15: 33: 22\end{array}$ & $\begin{array}{l}\text { Mariana de Paiva } \\
\text { Batista }\end{array}$ & Aceito \\
\hline Outros & Acordo_Biorrepositorio_AC.pdf & $\begin{array}{c}08 / 12 / 2015 \\
14: 49: 07\end{array}$ & $\begin{array}{l}\text { Mariana de Paiva } \\
\text { Batista }\end{array}$ & Aceito \\
\hline Outros & Acordo_Biorrepositorio_IVO.docx & $\begin{array}{c}08 / 12 / 2015 \\
14: 48: 28\end{array}$ & $\begin{array}{l}\text { Mariana de Paiva } \\
\text { Batista }\end{array}$ & Aceito \\
\hline Outros & Acordo_Biorrepositorio_IVO.pdf & $\begin{array}{c}08 / 12 / 2015 \\
14: 47: 52 \\
\end{array}$ & $\begin{array}{l}\text { Mariana de Paiva } \\
\text { Batista } \\
\end{array}$ & Aceito \\
\hline Outros & Acordo_Biorrepositorio_HC.docx & $\begin{array}{c}08 / 12 / 2015 \\
14: 47: 23\end{array}$ & $\begin{array}{l}\text { Mariana de Paiva } \\
\text { Batista }\end{array}$ & Aceito \\
\hline Outros & Acordo_Biorrepositorio_HC.pdf & $\begin{array}{c}08 / 12 / 2015 \\
14: 46: 59\end{array}$ & $\begin{array}{l}\text { Mariana de Paiva } \\
\text { Batista } \\
\end{array}$ & Aceito \\
\hline Outros & Declaracao_da_pesquisadora.docx & $\begin{array}{c}08 / 12 / 2015 \\
14: 46: 06\end{array}$ & $\begin{array}{l}\text { Mariana de Paiva } \\
\text { Batista }\end{array}$ & Aceito \\
\hline Outros & Declaracao_da_pesquisadora.pdf & $\begin{array}{c}08 / 12 / 2015 \\
14: 45: 38\end{array}$ & $\begin{array}{l}\text { Mariana de Paiva } \\
\text { Batista }\end{array}$ & Aceito \\
\hline Outros & $\begin{array}{l}\text { Parecer_favoravel_ao_projeto_TRADUC } \\
\text { AO.docx }\end{array}$ & $\begin{array}{c}08 / 12 / 2015 \\
14: 44: 44\end{array}$ & $\begin{array}{l}\text { Mariana de Paiva } \\
\text { Batista }\end{array}$ & Aceito \\
\hline Outros & Parecer_favoravel_ao_projeto.pdf & $\begin{array}{c}08 / 12 / 2015 \\
14: 44: 16\end{array}$ & $\begin{array}{l}\text { Mariana de Paiva } \\
\text { Batista } \\
\end{array}$ & Aceito \\
\hline Outros & \begin{tabular}{|l|} 
Parecer_favoravel_ao_Termo_de_Biodis \\
ponibilidade TRADUCAO.docx
\end{tabular} & $\begin{array}{c}08 / 12 / 2015 \\
14: 43: 34\end{array}$ & $\begin{array}{l}\text { Mariana de Paiva } \\
\text { Batista }\end{array}$ & Aceito \\
\hline Outros & $\begin{array}{l}\text { Parecer_favoravel_ao_Termo_de_Biodis } \\
\text { ponibilidade.pdf }\end{array}$ & $\begin{array}{c}08 / 12 / 2015 \\
14: 42: 25\end{array}$ & $\begin{array}{l}\text { Mariana de Paiva } \\
\text { Batista }\end{array}$ & Aceito \\
\hline Outros & $\begin{array}{l}\text { Termo_de_Biodisponibilidade_TRADUC } \\
\text { AO.doc }\end{array}$ & $\begin{array}{c}08 / 12 / 2015 \\
14: 38: 48\end{array}$ & $\begin{array}{l}\text { Mariana de Paiva } \\
\text { Batista }\end{array}$ & Aceito \\
\hline Outros & Termo_de_Biodisponibilidade.doc & $\begin{array}{c}08 / 12 / 2015 \\
14: 38: 20\end{array}$ & $\begin{array}{l}\text { Mariana de Paiva } \\
\text { Batista }\end{array}$ & Aceito \\
\hline Outros & Termo_de_Biodisponibilidade.pdf & $\begin{array}{c}08 / 12 / 2015 \\
14: 37: 38\end{array}$ & $\begin{array}{l}\text { Mariana de Paiva } \\
\text { Batista }\end{array}$ & Aceito \\
\hline $\begin{array}{l}\text { TCLE / Termos de } \\
\text { Assentimento / } \\
\text { Justificativa de } \\
\text { Ausência } \\
\end{array}$ & Termo_de_Consentimento.doc & $\begin{array}{c}08 / 12 / 2015 \\
14: 36: 57\end{array}$ & $\begin{array}{l}\text { Mariana de Paiva } \\
\text { Batista }\end{array}$ & Aceito \\
\hline Outros & \begin{tabular}{|l|}
$\begin{array}{l}\text { Carta_de_Acordo_da_UPC_do_Hospital } \\
\text { das Clinicas.doc }\end{array}$ \\
\end{tabular} & $\begin{array}{c}08 / 12 / 2015 \\
14: 36: 14\end{array}$ & $\begin{array}{l}\text { Mariana de Paiva } \\
\text { Batista }\end{array}$ & Aceito \\
\hline
\end{tabular}

Endereço: SRNTV 701, Via W 5 Norte - Edifício PO 700, $3^{\circ}$ andar

Bairro: Asa Norte

UF: DF

CEP: $\quad 70.719-049$

Telefone: (61)3315-5877

E-mail: conep@saude.gov.br 


\section{COMISSÃO NACIONAL DE ÉTICA EM PESQUISA}

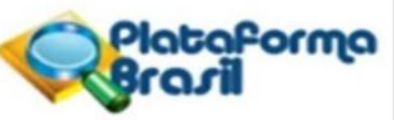

Continuação do Parecer: 2.630 .745

\begin{tabular}{|c|c|c|c|c|}
\hline Outros & \begin{tabular}{|l|} 
Carta_de_Acordo_da_UPC_do_Hospital \\
das Clinicas.pdf
\end{tabular} & $\begin{array}{c}08 / 12 / 2015 \\
14: 35: 45 \\
\end{array}$ & $\begin{array}{l}\text { Mariana de Paiva } \\
\text { Batista }\end{array}$ & Aceito \\
\hline Outros & $\begin{array}{l}\text { Carta_de_Acordo_do_Hospital_AC_Ca } \\
\text { margo.docx }\end{array}$ & $\begin{array}{c}08 / 12 / 2015 \\
14: 35: 18\end{array}$ & $\begin{array}{l}\text { Mariana de Paiva } \\
\text { Batista }\end{array}$ & Aceito \\
\hline Outros & $\begin{array}{l}\text { Carta_de_Acordo_do_Hospital_AC_Ca } \\
\text { margo.pdf }\end{array}$ & $\begin{array}{c}08 / 12 / 2015 \\
14: 34: 21 \\
\end{array}$ & $\begin{array}{l}\text { Mariana de Paiva } \\
\text { Batista }\end{array}$ & Aceito \\
\hline Outros & $\begin{array}{l}\text { CURRICULUM_VITAE_DA_PESQUISA } \\
\text { DORA.doc }\end{array}$ & $\begin{array}{c}08 / 12 / 2015 \\
14: 32: 51 \\
\end{array}$ & $\begin{array}{l}\text { Mariana de Paiva } \\
\text { Batista }\end{array}$ & Aceito \\
\hline $\begin{array}{l}\text { Projeto Detalhado / } \\
\text { Brochura } \\
\text { Investigador }\end{array}$ & Projeto_versao_1_1_de_12_06_15.pdf & $\begin{array}{c}08 / 09 / 2015 \\
12: 30: 10\end{array}$ & $\begin{array}{l}\text { Mariana de Paiva } \\
\text { Batista }\end{array}$ & Aceito \\
\hline Outros & \begin{tabular}{|l|} 
Carta_autorizacao_da_Patologia_AC_C \\
amargo COM NOME.doc
\end{tabular} & $\begin{array}{c}08 / 09 / 2015 \\
12: 16: 43 \\
\end{array}$ & $\begin{array}{l}\text { Mariana de Paiva } \\
\text { Batista }\end{array}$ & Aceito \\
\hline Outros & Carta_de_Acordo.doc & $\begin{array}{c}08 / 09 / 2015 \\
12: 13: 15\end{array}$ & $\begin{array}{l}\text { Mariana de Paiva } \\
\text { Batista }\end{array}$ & Aceito \\
\hline Outros & Formulario_SAME.xls & $\begin{array}{c}08 / 09 / 2015 \\
12: 12: 53 \\
\end{array}$ & $\begin{array}{l}\text { Mariana de Paiva } \\
\text { Batista }\end{array}$ & Aceito \\
\hline Outros & $\begin{array}{l}\text { Carta_autorizacao_dados_clinicos_AC_ } \\
\text { Camargo.doc }\end{array}$ & $\begin{array}{c}08 / 09 / 2015 \\
12: 12: 21\end{array}$ & $\begin{array}{l}\text { Mariana de Paiva } \\
\text { Batista }\end{array}$ & Aceito \\
\hline Outros & $\begin{array}{l}\text { Carta_autorizacao_da_Patologia_do_H } \\
\text { C.doc }\end{array}$ & $\begin{array}{c}08 / 09 / 2015 \\
12: 11: 25\end{array}$ & $\begin{array}{l}\text { Mariana de Paiva } \\
\text { Batista }\end{array}$ & Aceito \\
\hline Outros & $\begin{array}{l}\text { Cartas_de_autorizacao_IVO_TRADUZI } \\
\text { DA.doc }\end{array}$ & $\begin{array}{c}08 / 09 / 2015 \\
12: 10: 36\end{array}$ & $\begin{array}{l}\text { Mariana de Paiva } \\
\text { Batista }\end{array}$ & Aceito \\
\hline Outros & Cartas_de_autorizacao_IVO.doc & $\begin{array}{c}08 / 09 / 2015 \\
12: 07: 24 \\
\end{array}$ & $\begin{array}{l}\text { Mariana de Paiva } \\
\text { Batista }\end{array}$ & Aceito \\
\hline Outros & Carta_resposta.doc & $\begin{array}{c}08 / 09 / 2015 \\
12: 06: 46\end{array}$ & $\begin{array}{l}\text { Mariana de Paiva } \\
\text { Batista }\end{array}$ & Aceito \\
\hline
\end{tabular}

Situação do Parecer:

Aprovado

BRASILIA, 03 de Maio de 2018

\section{Assinado por: \\ Jorge Alves de Almeida Venancio \\ (Coordenador)}

\footnotetext{
Endereço: SRNTV 701, Via W 5 Norte - Edifício PO 700, $3^{\circ}$ andar

Bairro: Asa Norte CEP: 70.719-049

UF: DF Município: BRASILIA

Telefone: (61)3315-5877

E-mail: conep@saude.gov.br
} 